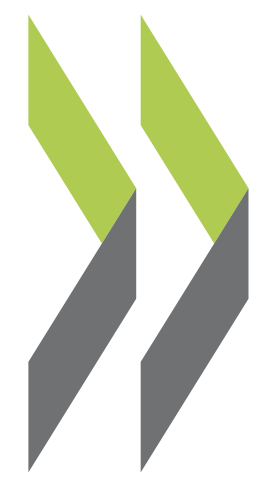

OECD Economics Department Working Papers No. 1339

How do policies influence

Aida Caldera Sánchez,

GDP tail risks?

Oliver Röhn

https://dx.doi.org/10.1787/5jln0428I1wl-en 
Organisation de Coopération et de Développement Économiques

Organisation for Economic Co-operation and Development

14-Nov-2016

ECONOMICS DEPARTMENT

English - Or. English

HOW DO POLICIES INFLUENCE GDP TAIL RISKS?

ECONOMICS DEPARTMENT WORKING PAPERS No. 1339

By Aida Caldera Sánchez and Oliver Röhn

OECD Working Papers should not be reported as representing the official views of the OECD or of its member countries. The opinions expressed and arguments employed are those of the author(s).

Authorised for publication by Christian Kastrop, Director, Policy Studies Branch, Economics Department.

All Economics Department Working Papers are available at www.oecd.org/eco/workingpapers

JT03405278

Complete document available on OLIS in its original format

This document and any map included herein are without prejudice to the status of or sovereignty over any territory, to the delimitation of international frontiers and boundaries and to the name of any territory, city or area. 
OECD Working Papers should not be reported as representing the official views of the OECD or of its member countries. The opinions expressed and arguments employed are those of the author.

Working Papers describe preliminary results or research in progress by the author(s) and are published to stimulate discussion on a broad range of issues on which the OECD works.

Comments on Working Papers are welcomed, and may be sent to OECD Economics Department, 2 rue André Pascal, 75775 Paris Cedex 16, France, or by e-mail to eco.contact@oecd.org.

All Economics Department Working Papers are available at www.oecd.org/eco/workingpapers

This document and any map included herein are without prejudice to the status of or sovereignty over any territory, to the delimitation of international frontiers and boundaries and to the name of any territory, city or area.

The statistical data for Israel are supplied by and under the responsibility of the relevant Israeli authorities. The use of such data by the OECD is without prejudice to the status of the Golan Heights, East Jerusalem and Israeli settlements in the West Bank under the terms of international law.

Latvia was not an OECD Member at the time of preparation of this publication. Accordingly, Latvia does not appear in the list of OECD Members and is not included in the zone aggregates.

\section{(C) OECD (2016)}

You can copy, download or print OECD content for your own use, and you can include excerpts from OECD publications, databases and multimedia products in your own documents, presentations, blogs, websites and teaching materials, provided that suitable acknowledgment of OECD as source and copyright owner is given. All requests for commercial use and translation rights should be submitted to rights@oecd.org 


\section{ABSTRACT/RÉSUMÉ \\ How do policies influence GDP tail risks?}

This paper explores the relationship between policy settings and extreme positive and negative growth events, what we call GDP tail risks, using quantile regression methods. Conditioning on several country characteristics such as the size, stage of development and openness to trade as well as macroeconomic policies, the following findings for a panel of mostly OECD countries emerge: First, countries with stronger banking supervision and capital market development, better quality of governance, higher foreign reserves and several labour market characteristics such as higher unemployment benefits and greater spending in active labour market policies tend to experience less severe negative growth shocks (negative tail risk). Second, greater use of macro-prudential tools is generally associated with less extreme positive growth shocks (positive tail risk) and lower average growth. Third, larger automatic stabilisers are associated with both less severe negative and positive growth shocks but also lower average growth.

JEL classification codes: C22; E32; E44; F3; F43

Keywords: downside risk, quantile regressions, financial stability, growth

$* * * * * * * * *$

\section{Comment les politiques publiques influencent les risques extrêmes du PIB?}

Cet article explore la relation entre les politiques publiques et les épisodes de croissance extrême positive et négative, ce que nous appelons risques extrêmes du PIB, en utilisant des méthodes de régression quantile. Une fois pris en compte plusieurs caractéristiques des pays tels que la taille, le stade de développement et de l'ouverture au commerce ainsi que les politiques macro-économiques, les résultats suivants pour un panel de la plupart des pays de l'OCDE se dégagent: Premièrement, les pays avec une supervision bancaire plus forte, un plus grand développement du marché des capitaux, une meilleure qualité de gouvernance, des réserves de change plus élevées et plusieurs caractéristiques du marché du travail tels que les prestations de chômage plus élevées et des dépenses plus importantes consacrées aux politiques du marché du travail actives ont tendance à subir des chocs de croissance négatifs moins graves (risque de queue négative). En second lieu, une plus grande utilisation des outils macro-prudentiels est généralement associée à des chocs positifs de croissance moins extrêmes et une croissance moyenne inférieure. Troisièmement, les stabilisateurs automatiques sont associés à des chocs de croissance négative et positive moins importants, mais aussi une croissance moyenne plus faible.

Classification JEL: C22; E32; E44; F3; F43

Mots clefs: risque négatif, régression quantile, stabilité financière, croissance 


\section{TABLE OF CONTENTS}

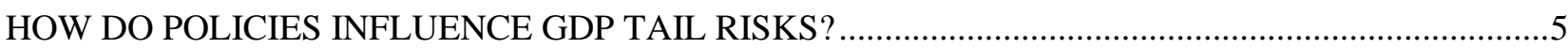

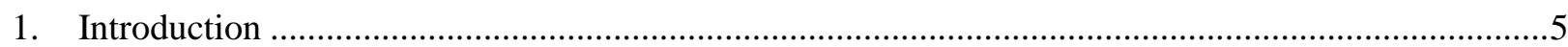

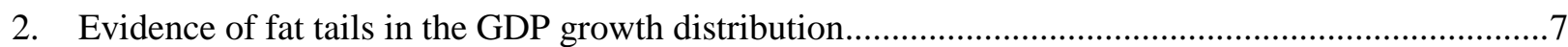

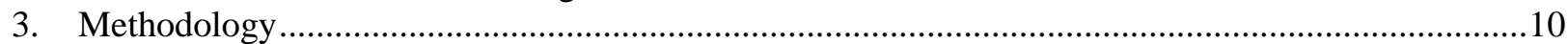

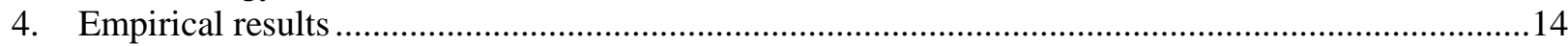

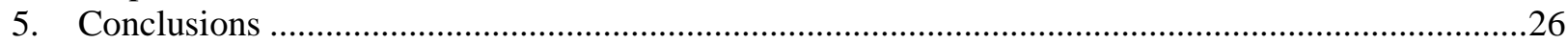

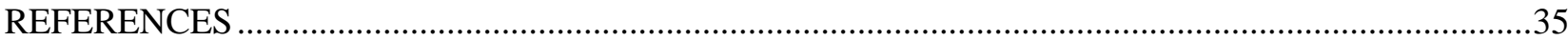

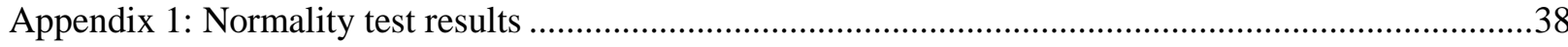

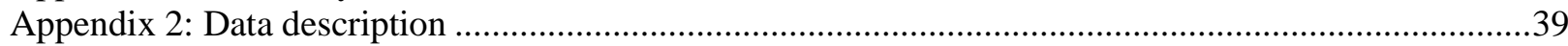

\section{Tables}

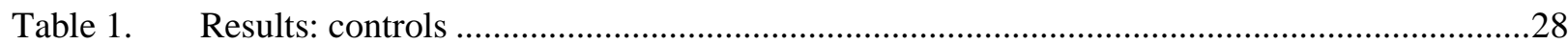

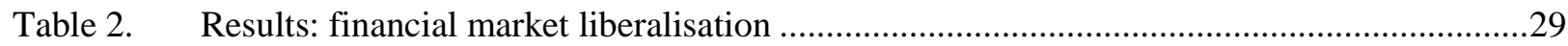

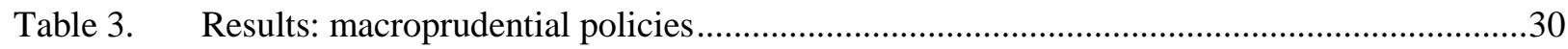

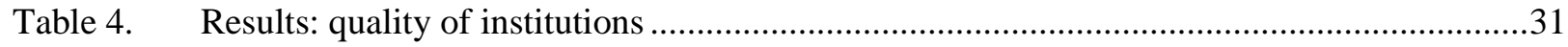

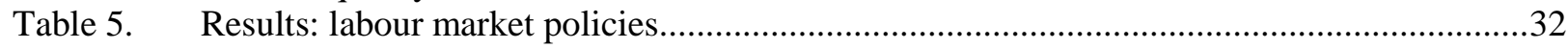

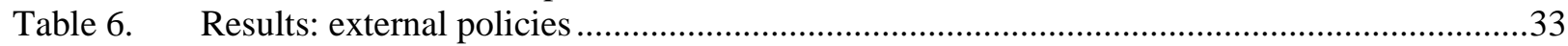

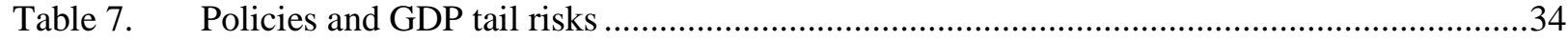

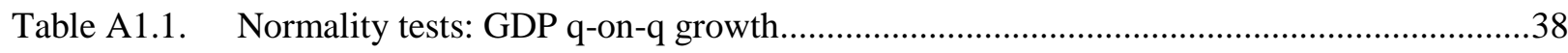

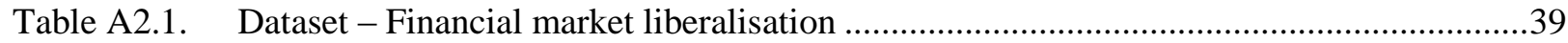

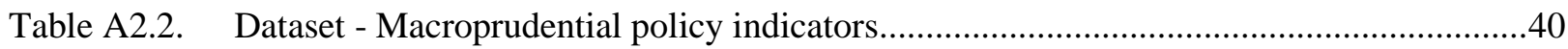

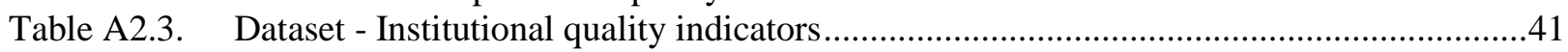

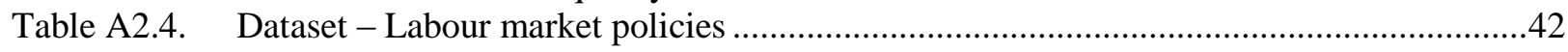

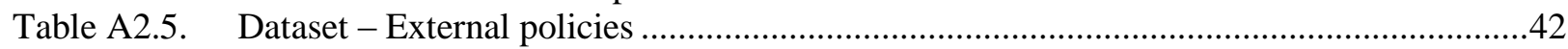

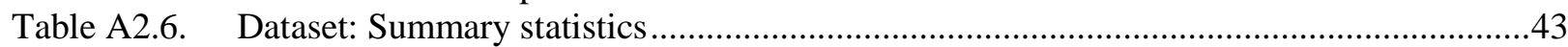

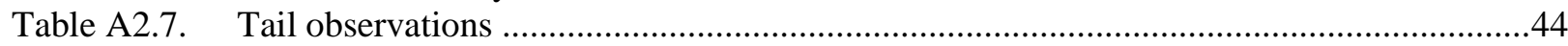

\section{Figures}

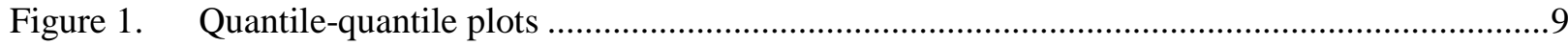

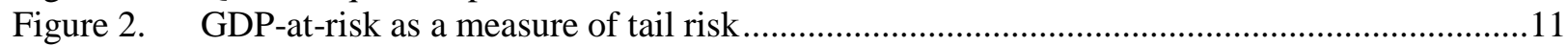

Figure 3. Quantile regression: an illustration ................................................................................ 12

Figure 4. The relationship between banking supervision and GDP tail risk....................................16

Figure 5. The relationship between capital market development and GDP tail risk ............................17

Figure 6. The relationship between macroprudential policies and GDP tail risk ..............................19

Figure 7. The relationship between institutional quality and GDP tail risk ......................................21

Figure 8. The relationship between unemployment benefits and GDP tail risk ................................22

Figure 9. The relationship between active labour market policies and GDP tail risk .........................22

Figure 10. The relationship between wage bargaining coordination and GDP tail risk ....................24

Figure 11. The relationship between capital account openness and GDP tail risk ...........................25

Figure 12. The relationship between foreign exchange reserves and GDP tail risk ........................26 


\title{
HOW DO POLICIES INFLUENCE GDP TAIL RISKS?
}

\author{
By Aida Caldera Sánchez and Oliver Röhn ${ }^{1}$
}

\section{Introduction}

The Great Recession has led to the need for a better understanding of the drivers of deep downturns. For policymakers a key issue is what type of policy frameworks can best mitigate the likelihood and depth of such great recessions and strengthen the resilience of economic and financial systems.

This paper explores how policy settings are related to GDP tail risks. We define GDP tail risks as extreme positive and negative higher frequency fluctuations in GDP, measured throughout most of the paper as quarterly GDP growth. To that end, we employ quantile regression methods, a relatively novel technique in the macroeconomic context. Quantile regressions allow us to assess the impact of explanatory variables on all parts of the conditional GDP distribution, not only its conditional mean. ${ }^{2}$ The paper limits itself to investigating higher frequency fluctuations. Hence the approach used in this paper does not directly shed light on the drivers of prolonged slumps or of long periods of unsustainable booms. We empirically assess the relationship between GDP tail risks and policies over a broad range of areas, from macroprudential policies, to banking supervision, to labour market policies or the quality of institutions. Conditioning on several country characteristics such as the size, stage of development and openness to trade as well as macroeconomic policies, the following findings for a panel of mostly OECD countries emerge:

- Automatic stabilisers: Countries with stronger automatic stabilisers experience less extreme positive and negative growth shocks. The results also show that the benefits in terms of output stabilisation of higher automatic stabilisers may come at the price of lower average growth. Unemployment insurance spending, which accounts for the lion share of automatic stabilisers on the spending side in most OECD countries, seems to be only associated with less positive growth shocks while no significant correlation is found on the lower tail.

\section{- Financial markets characteristics:}

- Countries with more effective prudential banking supervision experience less severe negative growth shocks. There is also some evidence that effective prudential banking supervision is associated with less positive growth shocks. Furthermore, consistent with Cournède et al. (2015) the results suggest that more developed capital markets are associated with higher growth on average. This paper complements their findings by showing that more developed capital markets are associated with less severe negative growth shocks and hence lower negative tail

1. The authors are members of the Economics Department of the OECD. They would like to thank the following OECD colleagues: Alain de Serres, Jean-Marc Fournier; Mikkel Hermansen, Filippo Gori, Catherine L. Mann; Hermès Morgavi, Jean-Luc Schneider and Douglas Sutherland (Economics Department) and Pierre Poret (Directorate for Financial and Enterprise Affairs) and thank Caroline Abettan for technical assistance.

2. The conditional distribution is the virtual distribution that results after holding fixed observable characteristics at a particular value (e.g. Fournier and Koske, 2012). 
risk. For instance, in countries with more developed capital markets firms might be able to better smooth investment during negative growth shocks. A drawback of the financial liberalisation data is that it only extends to 2005 and thus does not include the global financial crisis.

- Macroprudential measures are relatively new tools and experience with macroprudential policy in our sample of mostly OECD countries has been so far limited. Keeping this caveat in mind the results suggest that the use of several macroprudential policies is associated with less extreme positive growth shocks. This result is consistent with findings in the literature that macroprudential policies are mainly ex-ante policies meant to reduce the boom phase of the economic cycle (e.g. Cerutti et al., 2015). However, during more normal times there appears to be a cost involved in their use in terms of reduced average growth.

\section{- Labour market policies:}

- Higher spending on active labour market policies is associated with less extreme negative growth shocks.

- Higher minimum wages are associated with lower negative GDP tail risks. A possible interpretation of this result is that higher minimum wages buffer negative shocks, preventing wages at the lower end of the distribution from bearing the brunt of adjustment and holding up consumption. This wage effect appears to overcompensate potential negative employment effects.

- The quality of institutions emerges as a key factor for GDP tail risks:

- Countries with better quality institutions experience less severe negative growth shocks. Greater government effectiveness can help to manage macroeconomic risks properly. It may help to avoid, for instance, coordination failures among policymakers, or uncertainty regarding policy actions, which may lead to instability and lower growth.

\section{- External policies:}

- Greater capital account openness is associated with more negative GDP tail risk, which corroborates the view that more open economies are more exposed to higher financial and economic volatility.

- Higher accumulation of international reserves is associated with less severe negative growth shocks, in line with the role of reserves as a tool to limit exchange rate volatility and cushion aggregate domestic demand during current account reversals.

This work sets itself in a literature that focuses on the sources and consequences of large economic fluctuations that is still in its infancy and is expanding quickly. A small literature studies the drivers of large economic downturns (reviewed in Acemoglu et al. (2015)). Most recently, Acemoglu et al (2015) argue that macroeconomic tail risks can have their origins in idiosyncratic microeconomic shocks to disaggregated sectors, and demonstrate that sufficiently high levels of sectoral heterogeneity can lead to systematic departures in the frequency of large economic downturns from what is implied by the normal distribution. Stiglitz (2015) argues that while real business cycles and New Keynesian theories with nominal rigidities may help explain certain historical episodes, alternative strands of New Keynesian 
economics focusing on financial market imperfections, credit, and real rigidities provide a more convincing interpretation of deep downturns, such as the Great Depression and the Great Recession. Yet he reckons that there is a rich research agenda ahead about what are the sources of these deep downturns.

A second related line of research, investigates how risk factors shape the distribution of macroeconomic outcomes. For example, Giglio et al (2016) study how systemic risk and financial market distress affect the distribution of shocks to real economic activity. De Nicolo and Luccheta $(2011,2012)$ build a systemic risk monitoring tool by combining dynamic factor VARs and quantile regressions techniques to construct forecasts of systemic risk indicators. Adrian et al. (2016) show that measures of financial conditions have significant influence in forecasts of downside vulnerability, whereas measures of economic conditions have significant predictive power only for the median of the distribution. Cecchetti and $\mathrm{Li}$ (2008) assess the impact of equity and property booms on the extreme tails of the distribution of deviations in output and prices from their trends. To do this, they bring together quantile regression techniques and VAR methods.

Most closely related to this study are papers that assess how policy variables affect countries according to their position on the conditional growth distribution. For example, Linnemann and Winkler (2015) combine quantile regression methods with VAR and local projection techniques to estimate the impact of government spending shocks on output and employment rates. Using US data they find that fiscal multipliers appear to be considerable larger when output is far below trend. Andini and Andini (2014) assess the effect of financial development on the growth distribution, including the tails, while Mello and Perrelli (2003) focus on the role of schooling.

The rest of the paper is structured as follows. Section 2 provides evidence of fat tails in the GDP distribution, which underscores the limitations of the standard deviation of GDP as a measure of aggregate fluctuations. This empirical fact further motivates the use of quantile regression techniques as a useful approach to assess GDP tail risks. Section 3 presents the empirical methodology. Section 4 describes the empirical results on how policy factors are related to GDP tail risks. Section 5 discusses policy implications to draw from the analysis.

\section{Evidence of fat tails in the GDP growth distribution}

This section confirms earlier evidence by Acemoglu et al. (2015) and Fagiolo et al. (2008) that the quarterly distribution of GDP growth in OECD economies is not normal, but rather has fat tails. This is supported by both formal normality tests and graphical inspection via quantile plots.

Figure 1 shows Quantile-quantile (Q-Q) plots of GDP growth rates for four selected OECD countries, for which the presence of fat tails is quite vivid. ${ }^{3}$ If the actual distribution were well described by a normal distribution, the points in the figures would approximately fall on the straight line $(y=x)$. The figures show that for all the selected countries the points deviate from the straight line at both ends of the distribution. This indicates the existence of fat tails; i.e. non-normal tails. The figures further show that the observations on the left lie below the straight line. This implies that the lower tails are fatter than the normal distribution, suggesting that large negative growth shocks are more likely than what the normal distribution would predict.

The normality tests confirm that the distribution of GDP growth is not normal. Several commonly used normality tests are employed, all of which have the null hypothesis that the variable of interest is normally distributed. Table A1.1 shows that the hypothesis that growth rates are normally distributed is

3. These plots have been done for 42 countries (34 OECD, BRIICS, Columbia and Latvia), but are not shown here for parsimony. The finding that GDP distributions differ from the normal distribution at the tails is confirmed for the majority of OECD countries. 
rejected for the large majority of countries, with the exception of Chile, Ireland, Iceland, Israel and Colombia. In almost all cases, a test that the distributions' kurtosis is equal to three can also be rejected, providing further evidence for the presence of fat tails.

The presence of fat tails implies that standard approaches to measuring economic volatility - e.g. the standard deviation of GDP growth rates - do not fully characterise the tails of the GDP distribution and therefore are less useful metrics to assess the frequency and depth of large downturns. Indeed, risks may vary significantly even across economies that exhibit otherwise identical behaviour in the case of moderate deviations (Acemoglu et al. 2015). 
Figure 1. Quantile-quantile plots

Germany

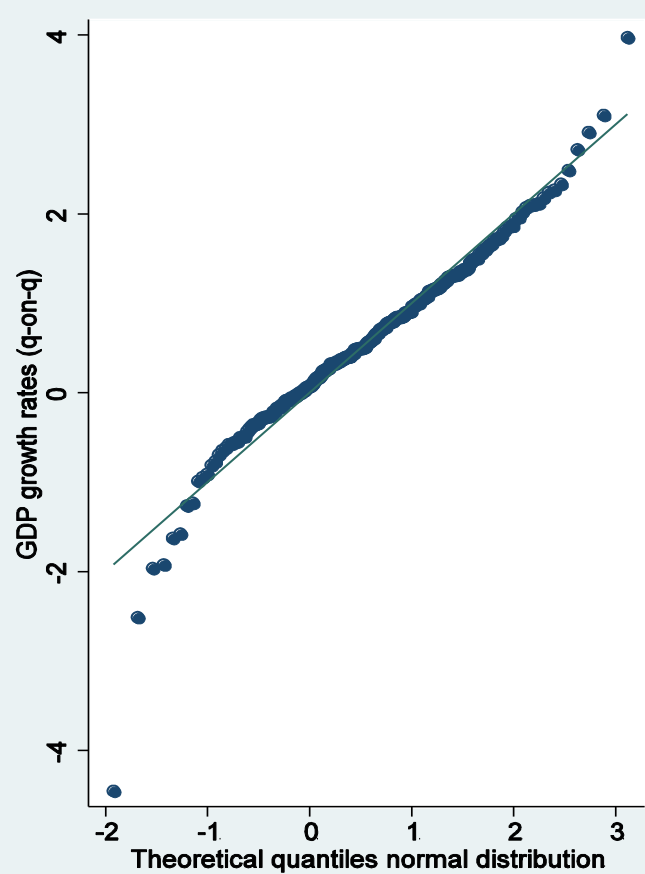

Italy

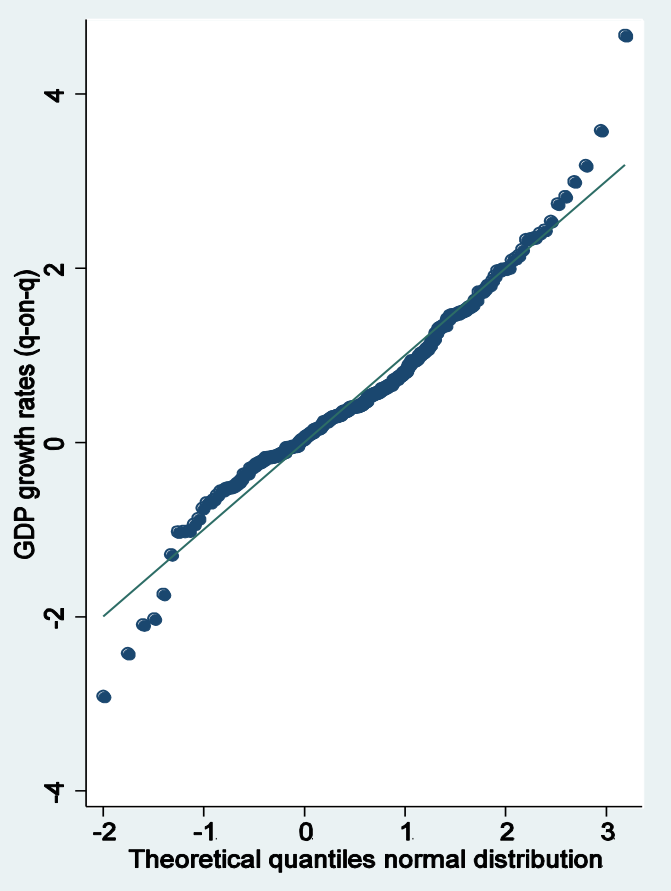

USA
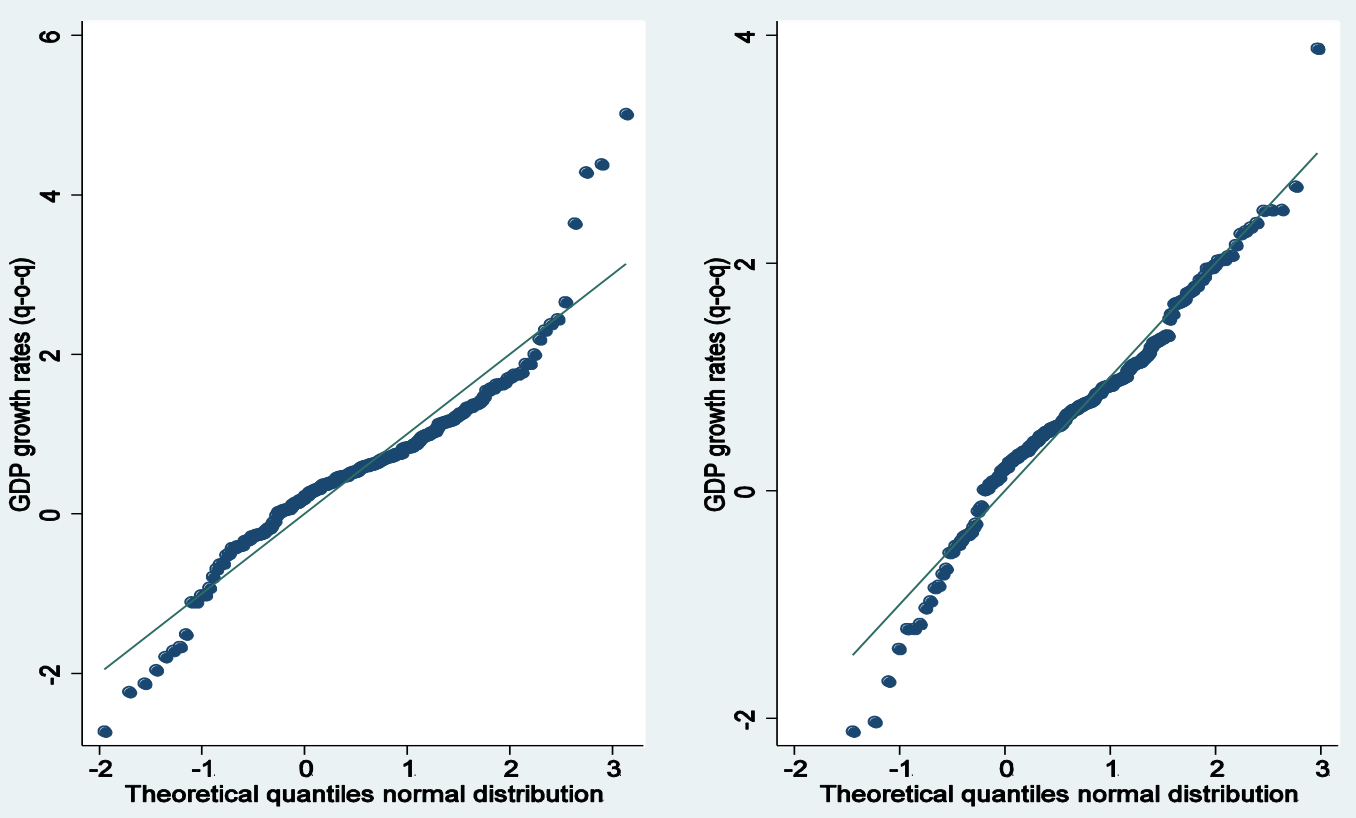

Note: Data period: 1960Q2 - 2014Q4. 


\section{Methodology}

The aim of this paper is to investigate how policy settings may influence tail risks, which is the risk of experiencing extreme negative and positive growth shocks. ${ }^{4}$ Tail risks can be measured by what is called in this paper GDP-at-risk. Similar to the well-known value-at-risk in finance, GDP-at-risk measures the worst outcome with a given probability. To fix ideas, let's consider a concrete example and assume that quarterly GDP growth rates are the outcomes of interest and the 5\% GDP-at-risk is $-3 \%$. This means that there is a $5 \%$ probability to observe a quarterly growth rate of $-3 \%$ or less. More generally the $\tau \%$-GDP-at risk corresponds to the $\tau$-th quantile of the GDP distribution (see Figure 2 below).

If policies influence tail risks this could be measured by a shift in GDP-at-risk. For example let's assume that a policy reduces negative tail risk and the 5\% GDP-at-risk changes from $-3 \%$ to $-1 \%$. This means that now with the same $5 \%$ probability one observes a quarterly growth rate of only $-1 \%$ or less. Put differently, there is now a less than 5\% chance to observe a quarterly GDP growth rate of $-3 \%$ or less. Hence if a policy mitigates negative tail risks, it means that with the same probability a less extreme outcome will be observed or equivalently the same extreme outcome will be observed with a lower probability.

Quantile regression methods naturally lend themselves to the analysis of GDP-at-risk, because they allow assessing the impact of explanatory variables on all the quantiles of the conditional distribution of GDP growth. Quantile regression techniques are therefore particularly useful to investigate whether policy variables do not only affect the location (the mean or median) of the conditional growth distribution but also the shape of the conditional distribution. This is different from more traditional OLS linear regressions that assess the impact on the conditional mean.

Another advantage of the method is that it allows investigating positive and negative tail risks separately. This is important because normative assessments of the two may differ. While there is probably a consensus on the need to avoid extreme negative growth events, the consensus is less clear for positive tail risks. For example, a quarter of strong positive growth could be a bounce back from an extreme negative quarter and hence be welcome. But, it could also be part of an unsustainable boom. However, there are also some drawbacks of employing quantile regression techniques, the most important ones being discussed below.

4. To give an illustration of the events this paper is interested in, Table A2.7 in Appendix 2 lists the countries and quarters that fall in the bottom $5 \%$ of the unconditional quarterly growth distribution. 
Figure 2. GDP-at-risk as a measure of tail risk

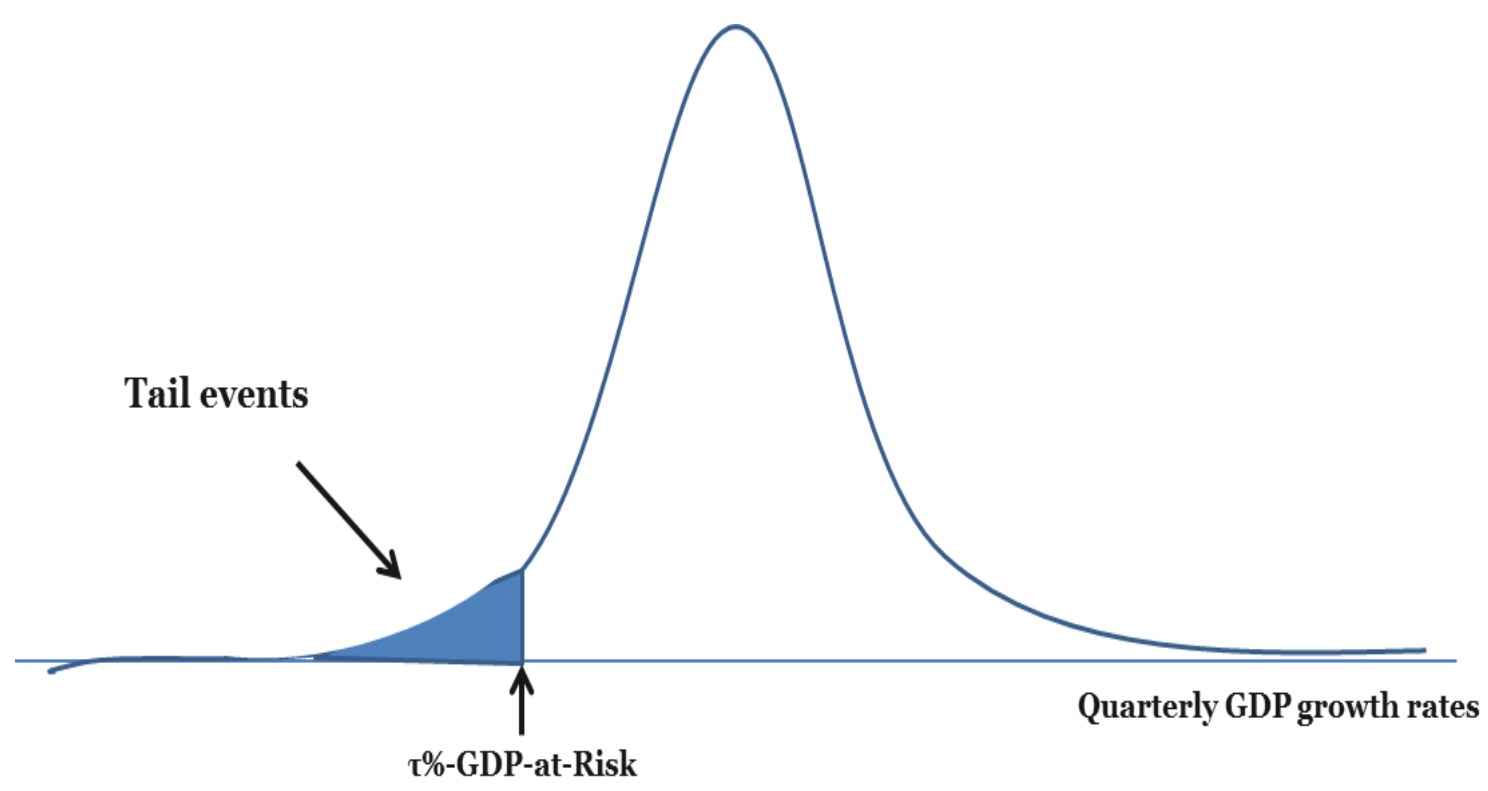

The following conditional quantile regression is estimated, where the $\tau^{\text {th }}$ conditional quantile of a random variable $\mathrm{y}$ is assumed to be a linear function of randomly distributed exogenous variables $\mathrm{X}$ :

$$
Q_{\tau}\left(y_{t} \mid X_{t}\right)=X_{t} \beta(\tau)
$$

where $\tau \in(0,1)$ is the $\tau^{\text {th }}$ conditional quantile. The outcome variable is GDP growth. The X variables include both control and policy variables that can influence the GDP growth distribution. These variables are discussed in more detail below.

Koenker and Basset (1978) propose to estimate the coefficient $\beta(\tau)$ by solving the following optimisation problem:

$$
\underset{\beta(\tau)}{\operatorname{argmin}} \sum_{i} \rho_{\tau}\left(y_{i}-x_{i} \beta(\tau)\right)
$$

where the check function $\rho_{\tau}$ is given by:

$$
\rho_{\tau}\left(y_{i}-x_{i} \beta(\tau)\right)= \begin{cases}\tau\left(y_{i}-x_{i} \beta(\tau)\right) & \text { if }\left(y_{i}-x_{i} \beta(\tau)\right) \geq 0 \\ (\tau-1)\left(y_{i}-x_{i} \beta(\tau)\right) & \text { if }\left(y_{i}-x_{i} \beta(\tau)\right)<0\end{cases}
$$

When estimating the effect of $\mathrm{X}$ on the median of $\mathrm{y}$ (i.e., $\tau=0.5$ ) the quantile regression estimator becomes equal to the least absolute deviations estimator, which minimizes the sum of absolute deviations. When focusing on effects at the centre of the distribution, the least absolute deviations estimator is more robust to extreme values than the standard OLS estimator which minimises the sum of squared deviations.

The coefficient of interest $\beta(\tau)$ is allowed to vary across quantiles and can be interpreted as the change in the $\tau^{t h}$ conditional quantile of y due to a change in X. The conditional distribution is the virtual distribution that results after holding fixed observable characteristics (the Xs) at a particular value (Fournier and Koske, 2012). In our case y are GDP growth rates and as discussed in more detail below, the $\mathrm{Xs}$ are a range of country characteristics that may influence the GDP growth distribution such as the size, 
stage of development, opennenes to trade and macroeconomic policies. As an example, when controlling for population and trade openness, a decrease of GDP by, for instance, $-2 \%$ in a small open country like Luxembourg, is regarded as less extreme than the same drop in GDP in a large and less open economy such as the US. Hence the paper investigates how policy variables affect the virtual GDP growth distribution of countries that share the same set of country characteristics and macroeconomic policies.

Figure 3 illustrates the case in which the coefficients on the quantiles above the median are larger than the coefficients on the quantiles below the median. In this case a change in the policy variable (X) increases the dispersion of the conditional growth distribution. Of course other effects of the policy variables on the conditional growth distribution are also possible. For example, policy variables may reduce the dispersion, affect the skewness, stretch one tail or fatten the other.

Given the interest in tail risks, the focus is on the results of the far left and far right quantiles of the conditional GDP growth distribution. In particular the results for the $5^{\text {th }}, 10^{\text {th }}, 90^{\text {th }}$ and $95^{\text {th }}$ quantile are reported. In addition, the results for the median $\left(50^{\text {th }}\right.$ quantile $)$ are reported to assess whether the effects on the tails are different from the effect on the centre of the conditional distribution. ${ }^{5}$ Finally, we also report the OLS estimates to allow comparing the results to standard approaches of assessing the average effects of policies on growth.

Figure 3. Quantile regression: an illustration

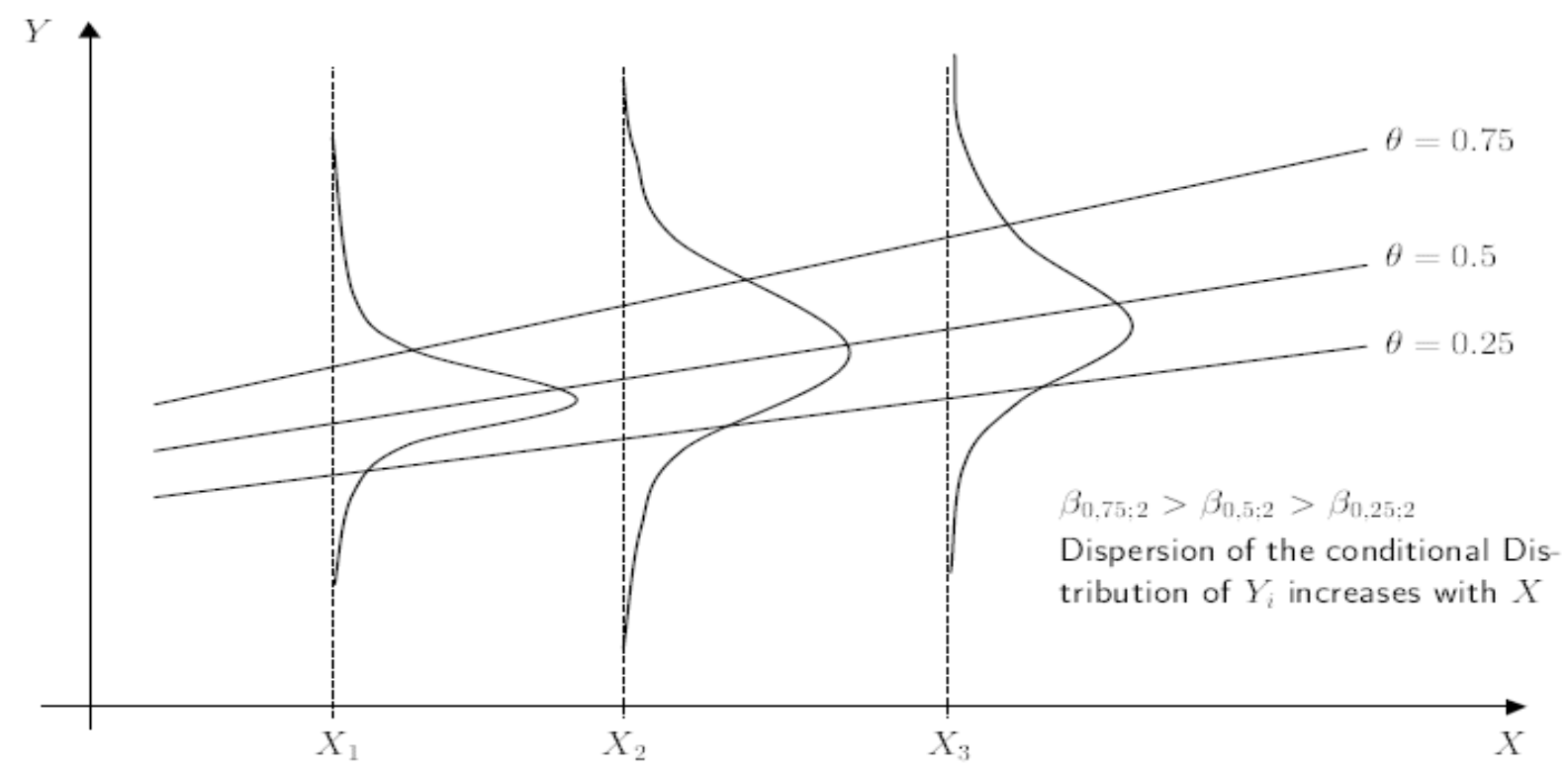

In the baseline an unbalanced panel with a maximum of 34 countries over the time period 1970-2014 at quarterly frequency is used (see Table A2.6 in Appendix 2 for summary statistics). ${ }^{6}$ Quarterly data is used because it has been employed most frequently to assess macroeconomic tail risks in the literature

5. Formal test results of whether the coefficients on the tails are different from the median are reported in the results tables below.

6. The 34 countries include all OECD countries except for Turkey and Chile, for which government revenue data is missing, as well as Latvia and Lithuania. 
most closely related to our study (Giglio et al., 2015; Cecchetti and Li, 2008; De Nicolo and Luccheta, 2012). Some of the drawbacks of using quarterly data are discussed below. ${ }^{7}$

As panel data is used it is important to account for unobserved country heterogeneity. Unfortunately in quantile regression models there is no general transformation of the data that can suitably eliminate unobserved heterogeneity such as the within transformation in the standard panel fixed effect model used in ordinary mean estimations (Kato et al. 2012). Quantile regression techniques suitable for panel data is still an active field of research and no preferred method has yet emerged from the literature nor have the methods found their way into standard software packages. Given these difficulties two different ways of (partly) accounting for unobserved country heterogeneity in the panel are used. Both methods share that the between variation in growth rates, which is likely to be particularly driven by unobserved heterogeneity, is suppressed, and hence identification relies on the within variation of GDP growth rates.

In the first approach the standard Koenker and Basset (1978) quantile regression model is run on the demeaned dependent variable, i.e. the country specific growth averages are subtracted from the dependent variable. By demeaning GDP growth, differences in mean growth rates across countries are accounted for and hence identification relies on the within variation of GDP growth rates. The advantage of this approach - compared to the standard within transformation and the second approach below - is that time-invariant and slow moving policy variables can be investigated. However the first approach may introduce a type of omitted variable bias because it fails to control for the means of the independent variables. This can be best seen when the approach is compared to the standard within transformation. In the standard within transformation both the dependent and the independent variables are demeaned. By failing to control for the mean of the independent variables, the first approach suffers from omitted variable bias if the independent variables are correlated with their country means, which is likely in practice (Gormley and Matsa, 2013). To ease readability the OLS results are only reported for this specification with demeaned quarterly growth rates.

The second approach follows Canay (2011) who provides a consistent and asymptotically normal two-step estimator under the assumption that fixed effects can be viewed as locational shift variables, i.e. variables that affect all quantiles of the distribution in the same way. Canay's empirical strategy is the following. In the first step, the empirical panel model of the form $Y_{i t}=\alpha_{i}+X_{i t} \beta+\epsilon_{i t}$ is estimated with the standard within estimator to obtain a consistent estimator of $\beta$. For large T a consistent estimator of $\alpha_{i}$ can then be obtained as $\hat{\alpha}_{\mathrm{i}}=\frac{1}{T} \sum_{t}\left(Y_{i t}-X_{i t} \hat{\beta}\right)$. In the second step, the standard quantile regression estimation (equation 1) is run on model $Y_{i t}^{*}=Y_{i t}-\hat{\alpha}_{\mathrm{i}}=\mathrm{X}_{\mathrm{it}} \beta+\epsilon_{\mathrm{it}}$. A disadvantage of this second approach, like in the standard within transformation, is that time invariant or slow moving policy variables cannot be investigated.

In an additional specification annual instead of quarterly data is used. ${ }^{8}$ The main reason is that policymakers may be more concerned about one year of very low growth compared to just one bad quarter. In addition, annual data may be less prone to measurement error compared to quarterly data and the large majority of our policy variables are only available at annual frequency which makes annual data arguably a more appropriate data frequency for our analysis. However, the significantly smaller number of observations may introduce a bias into the point estimate and the standard errors of the coefficients in the tails. More robust estimators for these cases are being developed in the literature but have not found their

7. If quarterly GDP data is simply interpolated annual data it is excluded from the subsequent analysis.

8. We also considered GDP deviations from an HP trend instead of GDP growth as the dependent variable. The results are broadly similar and are not reported for parsimony. 
way into standard software packages yet and could therefore not be applied in this paper. ${ }^{9}$ The annual results should therefore be interpreted with caution.

Identifying causal effects from policies to growth is in general difficult given reverse causality and the lack of suitable instruments. To mitigate endogeneity, policy variables are lagged by four quarters. ${ }^{10}$ Nevertheless the results should not be interpreted in a causal way. However interesting correlations may be discovered that stimulate further research into causal relationships.

\section{4. $\quad$ Empirical results}

\section{Control variables}

The baseline specification controls for several factors that are likely to influence the GDP growth distribution. Motivated by growth theory, the log of GDP per capita is included to capture conditional convergence effects. From open macroeconomic theory one would expect small and open economies to face different shocks compared to larger and more closed economies and to experience higher output volatility. To account for these effects the (log) of the population and trade openness, measured as exports plus imports in per cent of GDP, are also included in the baseline specification.

In addition to country characteristics the baseline controls for fiscal and monetary policies which are likely to affect short-term growth and influence the response to shocks. To capture fiscal policies, government revenues as a share of GDP are included, which is a commonly used and widely available proxy for the size of automatic stabilisers (e.g. Cottarelli and Fedelino, 2010). The size of the automatic stabilisers is likely to influence the response of output to shocks, with larger stabilisers expected to lead to more stable output. In the regressions below particular government spending items that act as automatic stabilisers, such as unemployment benefits, are also tested. To proxy for the monetary policy stance the real short-term interest rate is included (e.g. Linnemann and Winkler, 2015). ${ }^{11}$ We control for fiscal and monetary policy in the baseline specification because they are likely to be correlated with the more structural policies investigated below. For example, monetary policy decisions are likely to take the structural policy settings into account when reacting to a shock and monetary policy transmission mechanisms may depend on structural policy settings. Hence the failure to control for fiscal and monetary policies would introduce an omitted variable bias into the estimations below.

9. Chernozhukov and Fernández-Val (2011) develop a rule of thumb according to which standard quantile regression point estimates and standard errors are valid if $\tau \mathrm{T} / \mathrm{d}>15-20$, where $\tau$ is the quantile, $\mathrm{T}$ the total number of observations and $d$ the number of regressors. In most of the regressions below we consider 6 regressors. It follows that for $\tau=0.05(0.1)$ standard estimators and inference are valid if the number of observations exceeds 1800-2400 (900-1200). This is the case in most of the specifications using quarterly data but not for annual data. Chernozhukov and Fernández-Val (2011) develop inference methods that account for small sample bias. However these methods are not incorporated in standard software packages and could not be applied in this paper.

10. However, reverse causality may work against finding a significant effect. For example, policymakers may be more likely to adopt growth friendly reforms when growth is extremely low. This would imply a negative correlation from growth to policies which is particularly strong at the lower quantiles. If a positive coefficient is found on the lower quantiles this would imply that the causal effect running from policies to growth would overcompensate the negative effect stemming from reverse causality.

11. Using the real short-term interest rate is admittedly a crude proxy for the monetary policy stance. Using deviations from a Taylor rule may be a superior way to assess the stance of monetary policy with respect to the cycle. However, Taylor rules rely on neutral interest rates which are unobservable and hence need to be estimated. Estimating neutral interest rates for all countries in our sample is beyond the scope of this paper in particular given that monetary policy is not a variable of main interest. 
Table 1 presents the results for the control variables. The significantly negative coefficient on log GDP per capita on the median of the conditional growth distribution (and the OLS estimate) is in line with neoclassical growth models of conditional convergence. The coefficient is also negative for the other quantiles, however, not always significantly so. In addition, there is significant evidence that smaller countries do indeed experience higher volatility as one would expect from open economy macro models. The coefficient on $(\log )$ population is positive for the bottom quantiles while it is negative for the top quantiles, indicating that larger countries have a narrower conditional GDP growth distribution. The coefficients of trade openness are positive for the lower quantiles and negative for the upper quantiles, suggesting that higher trade openness is associated with a less dispersed conditional GDP growth distribution. ${ }^{12}$

Turning to the fiscal and monetary policy variables, the expected signs for the size of the automatic stabilisers are found. In particular, the coefficient on the government revenue variable is significantly positive for the bottom quantiles and negative for the top quantiles. This suggests that the conditional GDP growth distribution is narrower for countries with larger automatic stabilisers, i.e. they experience less severe negative growth shocks and smaller positive growth shocks. The fact that the coefficient is significantly negative on the median suggests that larger automatic stabilisers reduce growth on average. This is also corroborated by the negative albeit not significant OLS coefficient. A possible interpretation is that automatic stabilisers give rise to a possible trade-off between reducing negative tail risks on the one hand and reducing growth on average. The OLS coefficient on the real short interest rate is negative as expected. The quantile regression results show, however, that this result seems to be mainly driven by the negative association at the bottom quantiles.

\section{Financial market characteristics}

Theoretically, the link between financial markets and GDP tail risks is ambiguous. Deep and wellfunctioning financial markets can make economic agents less vulnerable to idiosyncratic shocks by reducing borrowing constraints enabling them to smooth consumption and investment. More developed financial markets may also strengthen monetary policy transmission and hence make monetary policy more effective in countering shocks.

At the same time, however, financial institutions can amplify output volatility through the so-called financial accelerator mechanism. Because of asymmetric information between lenders and borrowers, lenders care about the balance sheet of borrowers, in particular the net worth. In an upturn, the net worth of investors and consumers usually increases, which lowers agency costs (Bernanke and Gertler, 1989) because the borrower has more "skin in the game", and increases the value of collateral (Kiyotaki and Moore, 1997). Both effects will increase the supply of credit, boosting investment and consumption and fuelling the upturn. Asset prices will rise further improving borrowers' balance sheets and consequently further reducing borrowing constraints. In a downturn, this process is reversed, deepening the effect of a negative shock.

To investigate the link between financial market characteristics and GDP tail risks the paper uses the Abiad et al. (2008) database, which measures the various facets and gradations of financial reform (see Table A2.1 in Appendix 2 for details). The indicators range from 0-3 except for the aggregate index which is the sum of the individual components and ranges from 0-21. A higher value of the overall index

12. The sectoral composition of the economy may also influence the output response to shocks. However, common proxies such as the manufacturing employment share in total employment are only available for a short time-span and inclusion in the baseline results in a large drop in observations. Therefore the variable was not included in the set of control variables. 
indicates a more liberalised financial market. A drawback of the data is that it only extends to 2005 and thus does not include the global financial crisis. Three interesting results emerge.

First, there is evidence that the overall index (Finreform) is positively correlated with growth at the lower quantiles of the conditional GDP growth distributions (Table 2). This suggests that countries with more liberalised financial markets experience less severe negative growth shocks, i.e. they experience lower negative GDP tail risks. The effect at the top quantiles is generally negative albeit less robust, suggesting that more liberalised financial markets are associated with less positive growth shocks. Overall the results provide some evidence that more liberalised financial markets are associated with a reduced dispersion of the conditional growth distribution. The effect on the median is generally positive, however, not always significantly so.

Second, there is fairly robust evidence across specifications that effective prudential banking supervision (Superv) is positively correlated with growth at the lower quantiles of the conditional GDP growth distributions (Figure 4). This suggests that countries with more effective prudential banking supervision experience less severe negative growth shocks, i.e. they experience lower negative GDP tail risk. The coefficient on the $5^{\text {th }}$ quantile suggests that increasing the banking supervision indicator by one standard deviation increases quarterly growth by around 0.3 percentage points, a modest but economically significant effect (Figure 4). There is also evidence that effective prudential banking supervision has a negative effect on the top quantiles. This would suggest that effective prudential banking supervision is not only associated with less severe negative growth shocks but also with less positive growth shocks. The effect on the median changes across specifications. The results would be consistent with the interpretation that to the extent that effective prudential banking supervision can impede the build-up of financial imbalances it reduces the negative effect of their subsequent unfolding, thus reducing the exposure of an economy to extreme, finance induced, output fluctuations. For instance, inadequate banking supervision and, in turn, poorly underwritten residential mortgage contracts played a significant role in the run up to the financial crisis in some countries.

Figure 4. The relationship between banking supervision and GDP tail risk

Effect on GDP growth (q-on-q) of increasing the banking supervision indicator by one standard deviation, by quantile

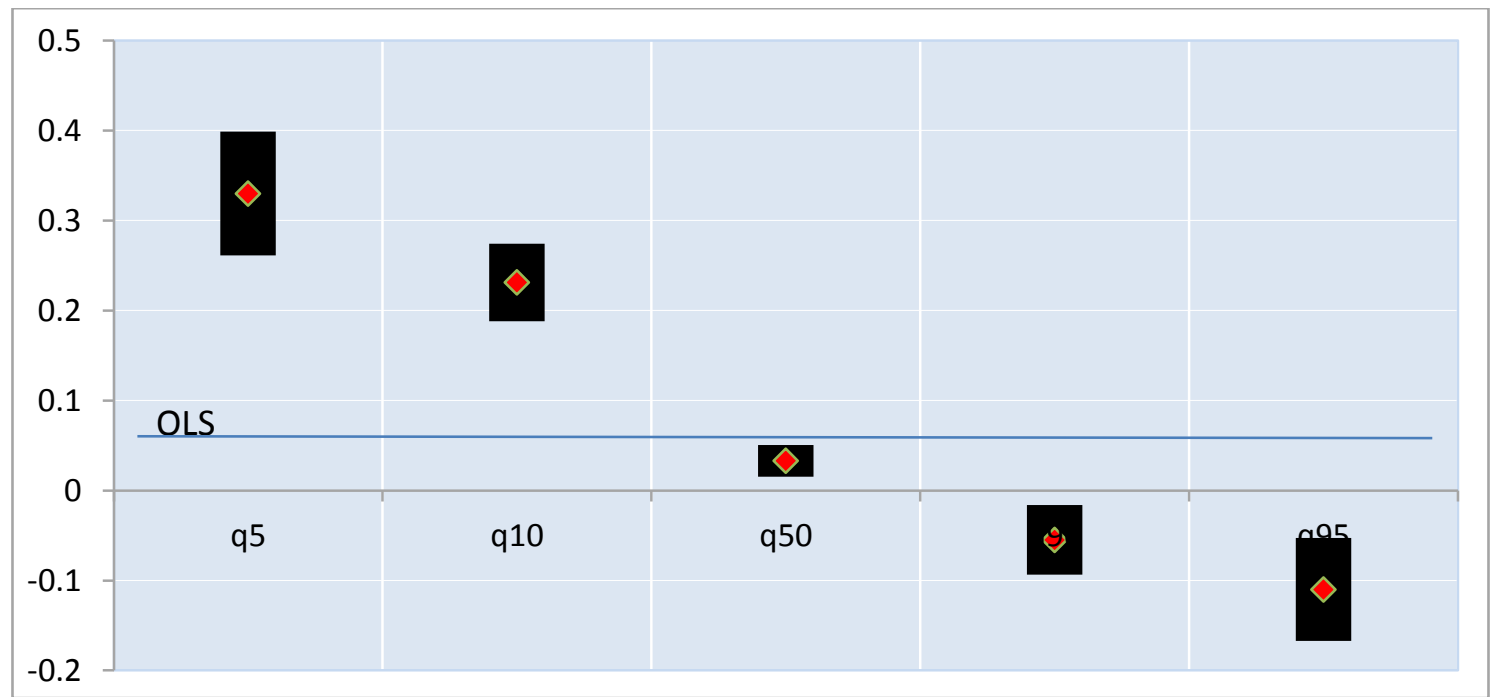

Note: The diamonds depict the point estimates and the thick bars a confidence interval of $+/-1$ standard deviation. The horizontal blue line depicts the OLS estimate. The estimates are based on the specification in the first panel of Table 2. 
More developed capital markets (here proxied with an index that captures the development of securities markets and openness of equity markets to foreign investors) are associated with less severe negative growth shocks (Figure 5). The coefficients on the lower quantiles also suggest an economically meaningful effect. One interpretation is that in countries with more developed capital markets, firms might be able to better cope with short-term demand changes and smooth investment during downturns, as they can access external financing or hedge risk more effectively. For example, in the midst of the Korean financial crisis of 1998, corporate bond markets provided all the funds raised by firms, with firms bypassing a troubled banking system (Laeven, 2014). The coefficients at the top quantiles are generally negative and significant except for annual data where the coefficients are insignificant. The effect on the median is generally significantly positive. This latter result is corroborated by the positive and significant OLS coefficient and is in line with Cournède et al. (2015) who find that stock market financing boosts growth in the average OECD country in contrast to bank credit which slows growth. The results in this paper complement their results by suggesting a smaller negative tail risk with higher capital market development.

Figure 5. The relationship between capital market development on GDP tail risk

Effect on GDP growth (q-on-q) of increasing the securities market development indicator by one standard deviation, by quantile

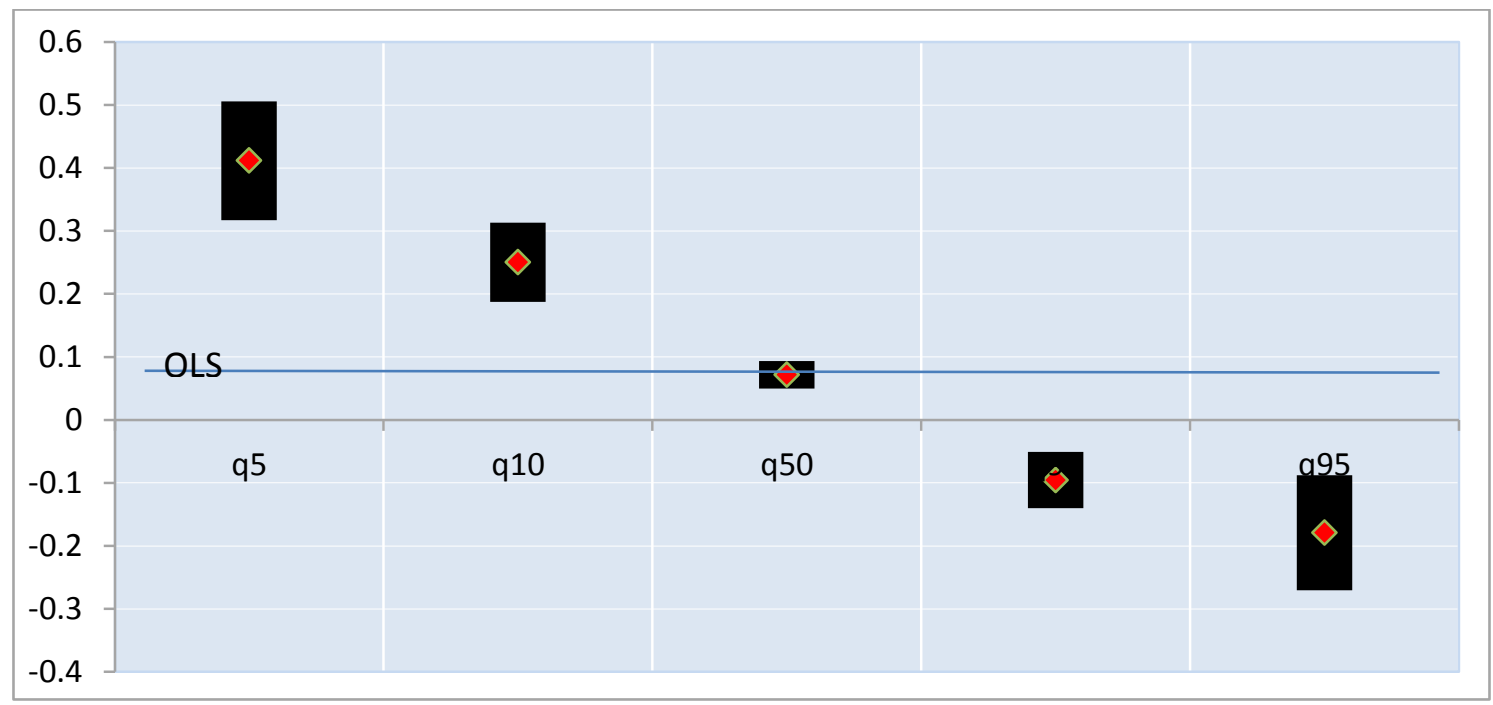

Note: The diamonds depict the point estimates and the thick bars a confidence interval of $+/-1$ standard deviation. The horizontal blue line depicts the OLS estimate. The estimates are based on the specification in the first panel of Table 2.

Evidence on the other financial liberalisation subcomponents generally confirm the findings of a significantly positive coefficient on the lower tails even if the findings are generally non-significant in the specification with annual data. Overall the findings suggest that different aspects financial liberalization are generally associated with lower negative tail risk. The coefficient on the upper quantiles is generally not significant for the subcomponents of financial liberalisation. An exception is ease of entry into the banking market. In that case the results also suggest that lower entry barriers are associated with less extreme positive growth shocks.

\section{Macroprudential policies}

Macro-prudential policies may affect GDP tail risks through at least two channels. First by reducing systemic threats to financial stability arising for example from excessive credit, leverage and asset price growth, they may decrease the probability that the financial sector becomes the source of a crisis. Second, 
macroprudential measures can increase the shock absorption capacity of the financial sector. For instance, capital and liquidity buffers increase the distance to default in case of an adverse shock.

Experience with macro-prudential tools is still limited and mostly confined to emerging economies, but some evidence on their beneficial effects has started to emerge. One of the first such studies is Lim et al. (2011). They analyse the links between several macroprudential policies and developments in credit and leverage and find that the measures are associated with reductions in the procyclicality of credit. Since this early study more evidence has accumulated. Limits on debt-to-income (DTI) and loan-to-value (LTV) ratios are associated with lower credit growth (IMF, 2012) and lower LTV ratios are found to slow house price inflation and contain feedbacks between assets prices and credit (e.g. Claessens, 2014; Crowe et al., 2013). In addition, Claessens et al. (2013) show that caps on DTI and LTV ratios and limits on credit growth and foreign currency lending are effective in reducing leverage, asset and non-core to core liabilities growth during boom times. Countercyclical buffers (such as reserve requirements, limits on profit distribution, and dynamic provisioning) also help mitigate increases in bank leverage and assets. Cerutti et al. (2015) find that emerging economies use macroprudential policies most frequently, especially foreign exchange related ones, while advanced countries use borrower-based policies more. Usage is generally associated with lower growth in credit, notably in household credit. Effects are less strong in financially more developed and open economies, however, and usage comes with greater cross-border borrowing, suggesting some avoidance. While macroprudential policies can help manage financial cycles, they work less well in busts. Making the link to the wider economy, Dell'Ariccia et al. (2012) find that macroprudential policies can reduce the incidence of general credit booms and decrease the probability that booms end up badly. This suggests that macroprudential policy can reduce the risk of a bust while simultaneously reducing the vulnerability of the rest of the economy to troubles in the financial system.

To investigate the link between macroprudential policies and the GDP growth distribution, a novel dataset on macroprudential regulations by Cerutti et al. (2015) is used. The dataset covers the period 20002013. Twelve single measures of their database are used together with three aggregated measures. The aggregate measures are those aimed at borrowers' leverage and financial positions; and those aimed at financial institutions' assets or liabilities as well as an overall macroprudential index which simply counts the number of measures in place. More details on the indicators can be found in Table A2.2 in Appendix 2.

There are several challenges involved when investigating the role of macroprudential policies. The most important being that the use of macroprudential measures in our sample of mostly OECD countries has been limited and hence the variation of the data is relatively low. The use of some measures is by now widespread. For example by 2013 half of the countries in our sample had some form of loan-to-value ratios in place. In contrast the use of other measures such as dynamic provisioning rules or countercyclical capital buffers had been confined to only one or two countries (dynamic provisioning in Spain and countercyclical capital buffers in Norway and Switzerland). This caveat should be kept in mind when interpreting the results. In addition, all of the indicators are binary measures that indicate whether a measure was in place or not and thus do not capture the intensity of measures, changes of intensity over time and whether the measures were binding at the time or not. However, such information is not available for a large set of countries and hence the dataset at hand is currently the best available source on macroprudential use across countries.

Turning first to the results of the aggregated measures in Table 3, there is relatively robust evidence across specifications that the overall macroprudential index (MPI) as well as the subset of borrowertargeted instruments (BORROWER) is significantly negatively correlated with GDP growth at the top quantiles of the conditional GDP growth distributions. This suggests that the use of macroprudential measures is associated with smaller positive growth shocks. Taking the coefficient on the overall macroprudential index on the $95^{\text {th }}$ quantile at face value (left panel in Table 3), suggests that the use of an additional macroprudential measure is associated with a reduction in quarterly growth by 0.1 percentage 
points, which is an economically meaningful but rather modest effect. There is also some evidence that these variables are positively correlated with growth at the bottom quantiles but the coefficients are generally not significant and vary across specifications. Finally there is evidence that greater use of macroprudential policies is negatively correlated with growth at the median. The OLS coefficient also suggests a negative effect on average. Overall, the evidence at the upper quantiles is consistent with findings in the literature that macroprudential policies are mainly ex-ante policies meant to reduce the boom phase of the economic cycle (e.g. Cerutti et al., 2015). However, during more normal times there appears to be a cost involved in their use in terms of reduced average growth.

Turning to the individual macroprudential tools, there are some interesting additional results. For the debt-to-income ratio (DTI) and taxes on financial institutions (TAX), there is in addition to the negative correlation with growth at the top quantiles some evidence of a significantly positive effect on the bottom quantiles, suggesting that the use of these measures is associated with less severe negative growth shocks. In the case of taxes on financial institutions the results show a significant negative correlation at the median, suggesting a cost in terms of reduced average growth. This finding is corroborated by the negative coefficient on the OLS estimate. The results on the use of countercyclical capital buffers (CTC) and capital surcharges on SIFIs also suggest a positive correlation with the bottom quantiles and a negative one with the top quantiles. However the variation in these two measures stems only from 2 countries and results should therefore be regarded as very preliminary.

The evidence on loan-to-value ratio caps (LTV_CAPS) (Figure 6) and limits on interbank exposures (INTER) is similar to the findings of the aggregate measures to the extent that they only appear to be negatively and significantly correlated at the upper quantiles of the conditional growth distribution. The coefficient for LTV_CAPS on the $95^{\text {th }}$ quantile suggests that the use of loan-to-value caps is associated with a reduction in quarterly growth by close to 0.5 percentage points, which is an economically significant effect. For both INTER and LTV_CAPS, the negative coefficients at the median and the negative OLS coefficient suggest a cost in terms of reduced average growth. Somewhat surprisingly for the indicators of loan-to-value ratios (LTV), which in contrast to the stricter loan-to-value ratio caps measure also captures mere regulatory guidelines on LTVs or risk-weights, there is some evidence of a negative correlation with the lower quantiles. This would suggest that this measure is associated with more severe negative growth shocks. Evidence on the other macroprudential measures is rather inconclusive with signs and significance levels changing across specifications for the bottom and the top quantiles.

Figure 6. The relationship between macroprudential policies and GDP tail risk Effect on GDP growth (q-on-q) of using a loan-to-value cap, by quantile

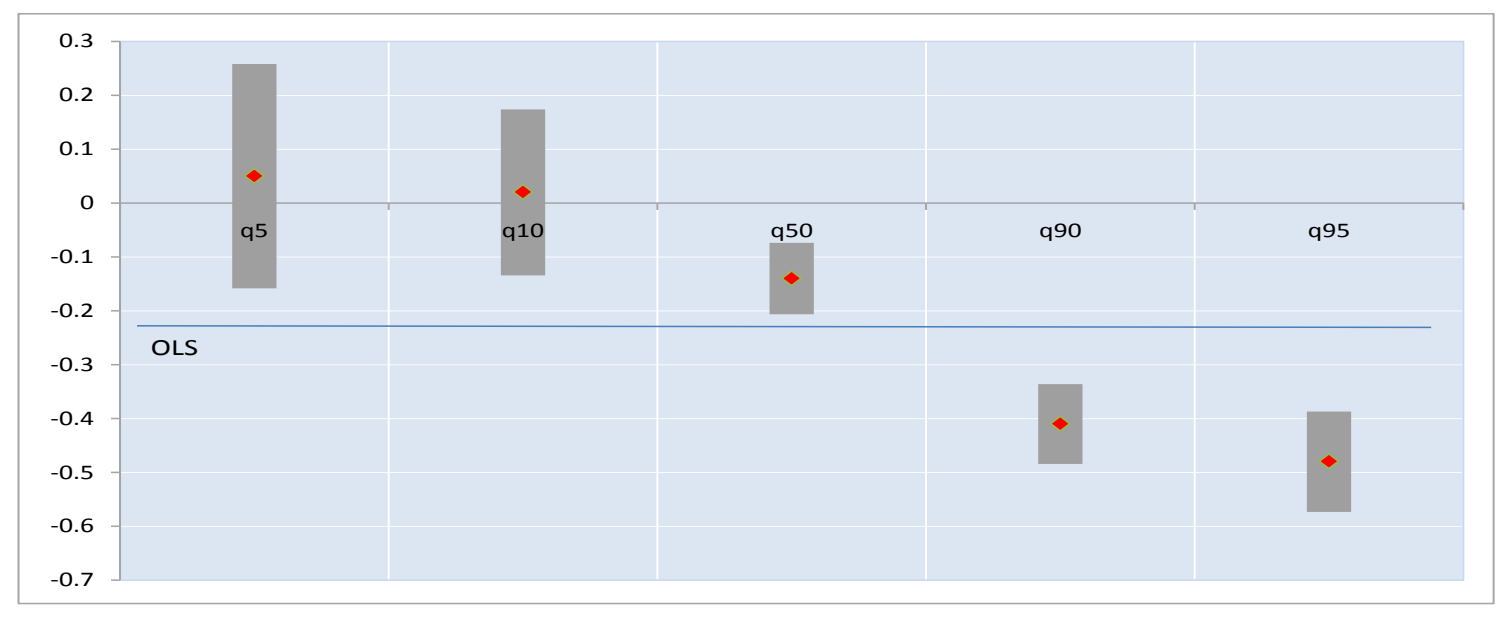

Note: The diamonds depict the point estimates and the thick bars a confidence interval of $+/-1$ standard error. The horizontal blue line depicts the OLS estimate. The estimates are based on the specification in the first panel of Table 3. 


\section{Institutional quality}

A number of channels have been put forward in the literature through which countries with lower quality of institutions may experience greater GDP tail risks (Acemoglu et al. 2003; Rodrik, 1998).

- Few constraints on rulers: in institutionally weak societies groups that gain politically may attempt to use power to redistribute rents and income to themselves and create economic turbulence, for example through social unrest.

- Greater infighting: in institutionally weak societies there will be greater infighting between various groups to control the state and take advantage of resulting rents, leading to greater political and economic turbulence.

- Hard to sustain cooperation in the face of shocks: with weak institutions economic cooperation may be difficult in the face of economic shocks, which can lead to deeper output collapses.

- Imperfect contractual arrangements: with weak institutions contractual arrangements will be more imperfect, making certain economic relationships more susceptible to shocks.

- Unsustainable policies: in societies with institutional problems politicians may pursue unsustainable policies to satisfy various groups and remain in power. For example, large government sectors and budget deficits, high inflation, overvalued exchange rates or high inflation discourage certain investments and unsustainable policies will lead to some sort of crisis.

- Capital withdrawal: with weak institutions, entrepreneurs may choose sectors/activities from which they can withdraw their capital more quickly, thus contributing to potential economic instability.

The quality of institutions is measured using the Worldbank Worldwide Governance indicators in six broad categories: voice and accountability, political stability and absence of violence, government effectiveness, regulatory quality, rule of law and control of corruption (see Table A2.3 in Appendix 2 for a detailed description). ${ }^{13}$ Higher values of the indices indicate stronger institutions. Given that the measures of institutional quality are highly persistent over time and the variation mainly stems from cross-country differences (see Table A2.6 in Appendix 2), the specification with country fixed effects is not reported.

Overall, regardless of the measure of institutions, results suggest that better quality institutions are positively correlated with GDP growth at the lower quantiles of the conditional GDP growth distribution (Table 4 and Figure 7). This suggests that countries with better quality institutions experience less severe negative growth shocks. Regarding the economic significance of these effects, for instance, the coefficient on the $5^{\text {th }}$ percentile suggests, that increasing the government effectiveness indicator by one standard deviation increases quarterly growth by around 0.2 percentage points (Figure 7), a modest but economically significant effect. An interpretation of this result is that greater government effectiveness can help to manage macroeconomic risks properly. It can help avoid, for instance, coordination failures among policymakers, or uncertainty regarding policy actions, which can lead to greater instability and lower growth. These results complement previous findings in the literaturesuggesting that countries with better institutions are likely to suffer lower volatility (measured as standard deviation of the growth rate) and less severe output collapses (measured by largest output drop in any year) (Acemoglu et al. 2003). The effect on growth at the median (and the OLS estimate) is generally also positive but often not significant.

13. As alternative measures of the quality of institutions, contract enforcement indicators sourced from the World Bank Doing Business database have been tested. However, results were generally inconclusive and are not reported. 
Figure 7. The relationship between institutional quality and GDP tail risk

Effect on GDP growth (q-on-q) of increasing the government effectiveness indicator by one standard deviation, by quantile

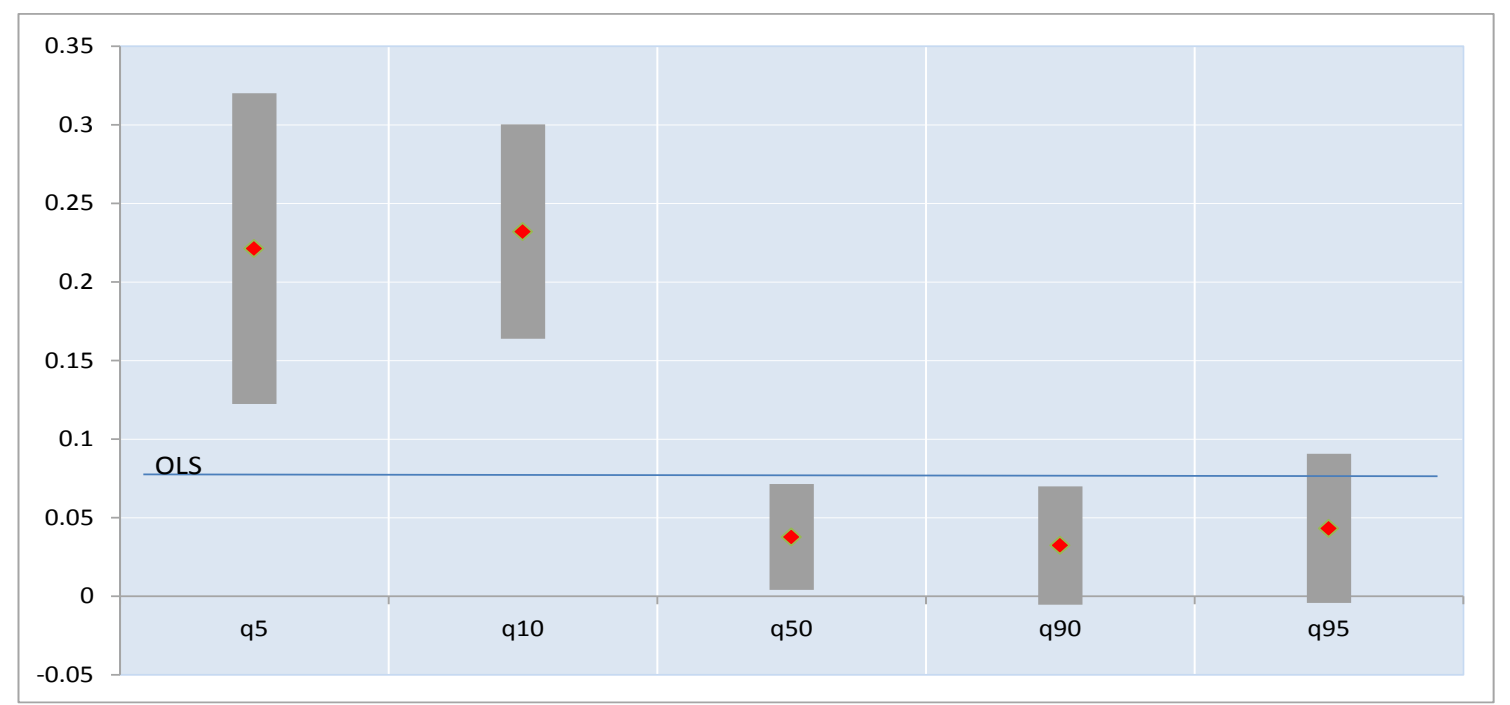

Note: The diamonds depict the point estimates and the thick bars a confidence interval of $+/-1$ standard deviation. The horizontal blue line depicts the OLS estimate. The estimates are based on the specification in the first panel of Table 4.

The evidence on the upper quantiles is generally inconclusive. While the effects are generally insignificant in the regressions with quarterly data they are negative and often significant in the regressions with annual data. An exception is political stability for which there is relatively robust evidence of a positive effect on the higher quantiles. This indicator measures perceptions of the likelihood of political instability and/or politically motivated violence in a country. Taken at face value, this result suggests that higher political stability magnifies positive growth shocks.

\section{Labour market policies}

Labour market institutions and policies can shape the distributional impact of shocks and help share risks across individuals in several ways. For example, unemployment benefit schemes insure income against job loss, sheltering individuals from the full effects of temporary negative shocks, thus playing a useful role as automatic stabilisers. For details on the data used in this section see Table A2.4 in Appendix 2.

\section{Unemployment benefits and active labour market policies}

There is relatively robust evidence across specifications that more generous unemployment benefits are negatively correlated with growth at the top quantiles of the conditional GDP growth distribution. Furthermore, there is some evidence that more generous unemployment benefits are positively correlated with growth at the lower quantiles of the conditional GDP growth distribution (Table 5 and Figure 8) suggesting that more generous unemployment benefits are associated with less severe negative growth shocks. However the latter evidence is not significant. Overall, these results provide some evidence that higher unemployment benefits are associated with a less dispersed conditional GDP growth distribution, in line with the role of unemployment benefits as automatic stabilisers. The effect at the median is negative, however, not significantly so. 
Figure 8. The relationship between unemployment benefits and GDP tail risk

Effect on GDP growth (q-on-q) of increasing unemployment benefits by one standard deviation, by quantile

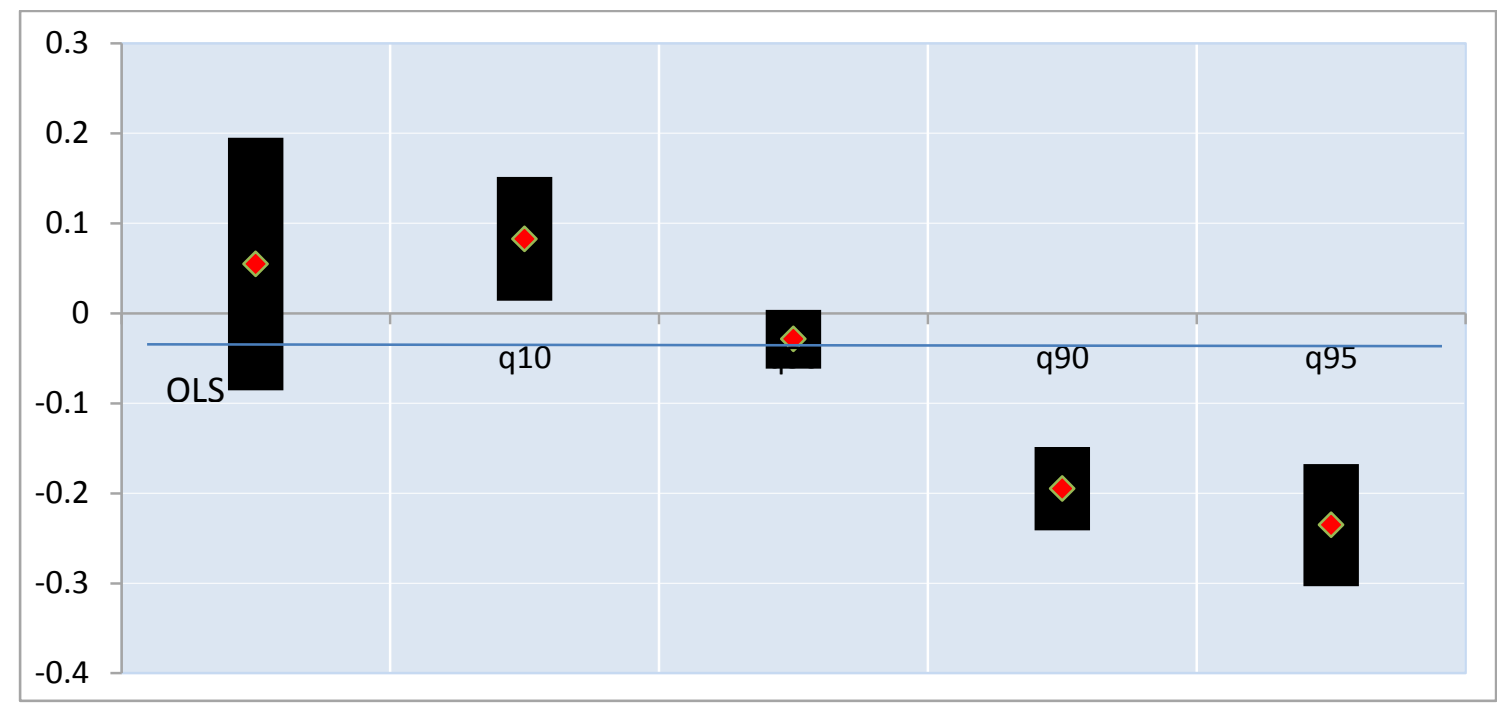

Note: The diamonds depict the point estimates and the thick bars a confidence interval of $+/-1$ standard deviation. The horizontal blue line depicts the OLS estimate. The estimates are based on the specification in the first panel of Table 5.

Turning next to the results on spending on active labour market policies, there is some evidence that higher spending in active labour market policies is positively correlated with growth at the lower quantiles of the conditional GDP growth distribution (Figure 9). This would suggest that higher spending in active labour market policies is associated with less negative growth shocks. For instance, the coefficient on the $5^{\text {th }}$ percentile suggests, that increasing the spending on active labour market policies by one standard deviation increases quarterly growth by around 0.25 percentage points. The effect at the median and the top quantiles is generally inconclusive with signs changing across specifications.

Figure 9. The relationship between active labour market policies and GDP tail risk

Effect on GDP growth (q-on-q) of increasing active labour market policies spending by one standard deviation, by quantile

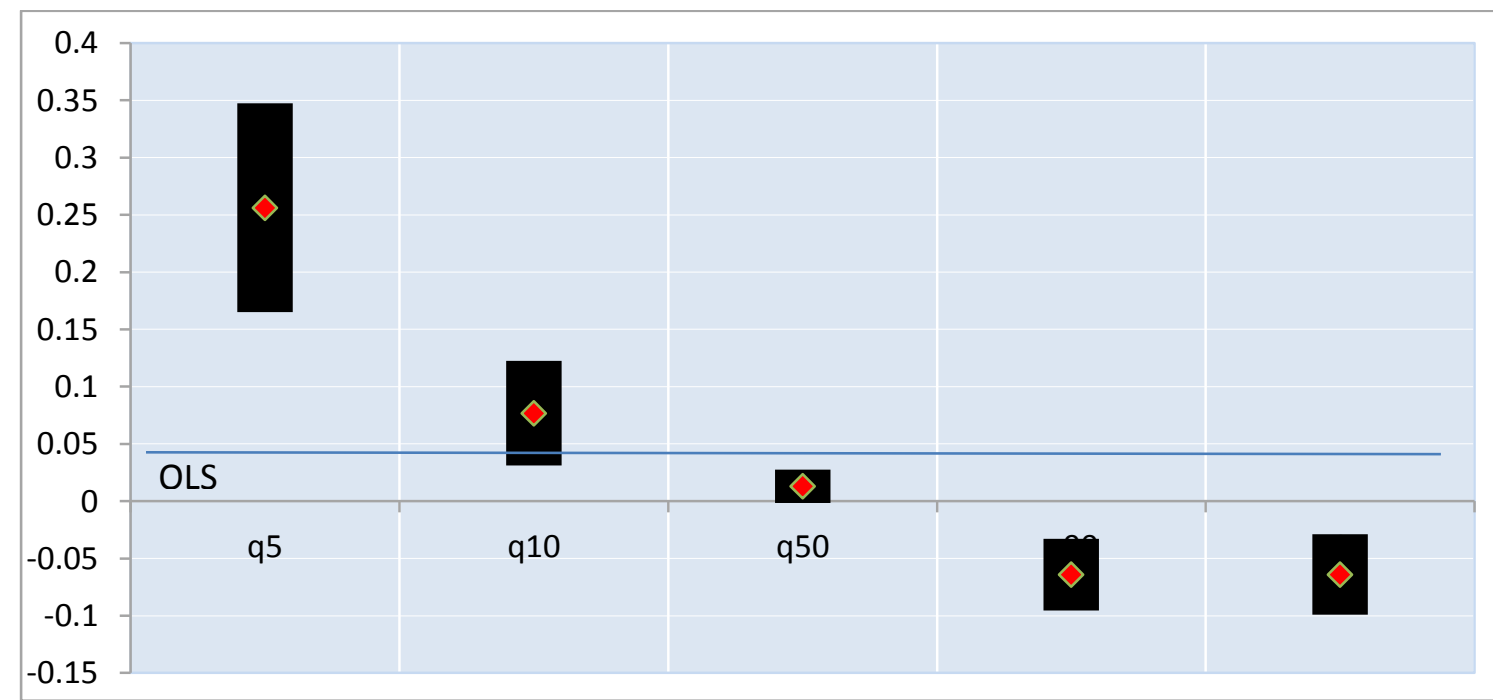

Note: The diamonds depict the point estimates and the thick bars a confidence interval of $+/-1$ standard deviation. The horizontal blue line depicts the OLS estimate. The estimates are based on the specification in the first panel of Table 5. 


\section{Minimum wages}

There is some evidence across specifications that a higher minimum wage is positively correlated with growth at the lower quantiles of the conditional GDP growth distribution (Table 5). This would suggest that higher minimum wages are associated with less negative growth shocks. A possible interpretation of this result is that in the face of a negative shock high minimum wages prevent nominal wages at the lower end of the distribution from bearing the brunt of adjustment, thus acting as a shock absorber. This result suggests that the positive income effect from minimum wages may overcompensate the likely negative effect on employment of higher minimum wages (e.g. Ahrend et al. (2011)). The evidence on the median is rather inconclusive with signs changing across specifications.

\section{Employment protection legislation (EPL)}

No conclusive evidence is found that employment protection (of regular contracts) affects the conditional GDP growth distribution with signs and significance of the coefficient changing across specifications for the bottom quantiles, the median, the OLS estimate and the top quantiles (Table 5).

\section{Wage bargaining institutions}

Wage bargaining institutions may influence GDP tail risks through their impact on the speed of wage adjustment following shocks. ${ }^{14}$ The evidence on the lower quantiles is inconclusive. On the other hand, there is evidence across specifications that a high degree of wage bargaining coordination is negatively correlated with growth at the higher quantiles of the conditional GDP growth distribution (Table 5 and Figure 10). ${ }^{15}$ The effect on the median is negative for a higher degree of wage bargaining coordination, although not always significant. This finding is corroborated by the OLS estimates and suggests that a high degree of wage bargaining coordination is associated with lower growth on average.

14. For instance, Blanchard et al. (2013) argue that in face of some shocks, for instance, when the price of oil increases sharply, centralised bargaining is likely to dominate firm-level bargaining as a better institution to facilitate adjustment to shocks for two reasons: because it can solve a coordination problem, and because it is likely to give more weight to the welfare of the unemployed. When wages are negotiated at the firmlevel the process of adjustment in which all wages, and in turn prices, adjust is likely to be protracted.

15 Using an alternative measure on wage setting characteristics, there is robust evidence across specifications that greater wage bargaining decentralisation is positively correlated with the higher quantiles of the conditional GDP growth distribution and with higher growth on average. 
Figure 10. The relationship between wage bargaining coordination and GDP tail risk Effect on GDP growth (q-on-q) of increasing the wage bargaining coordination indicator by one standard deviation, by quantile

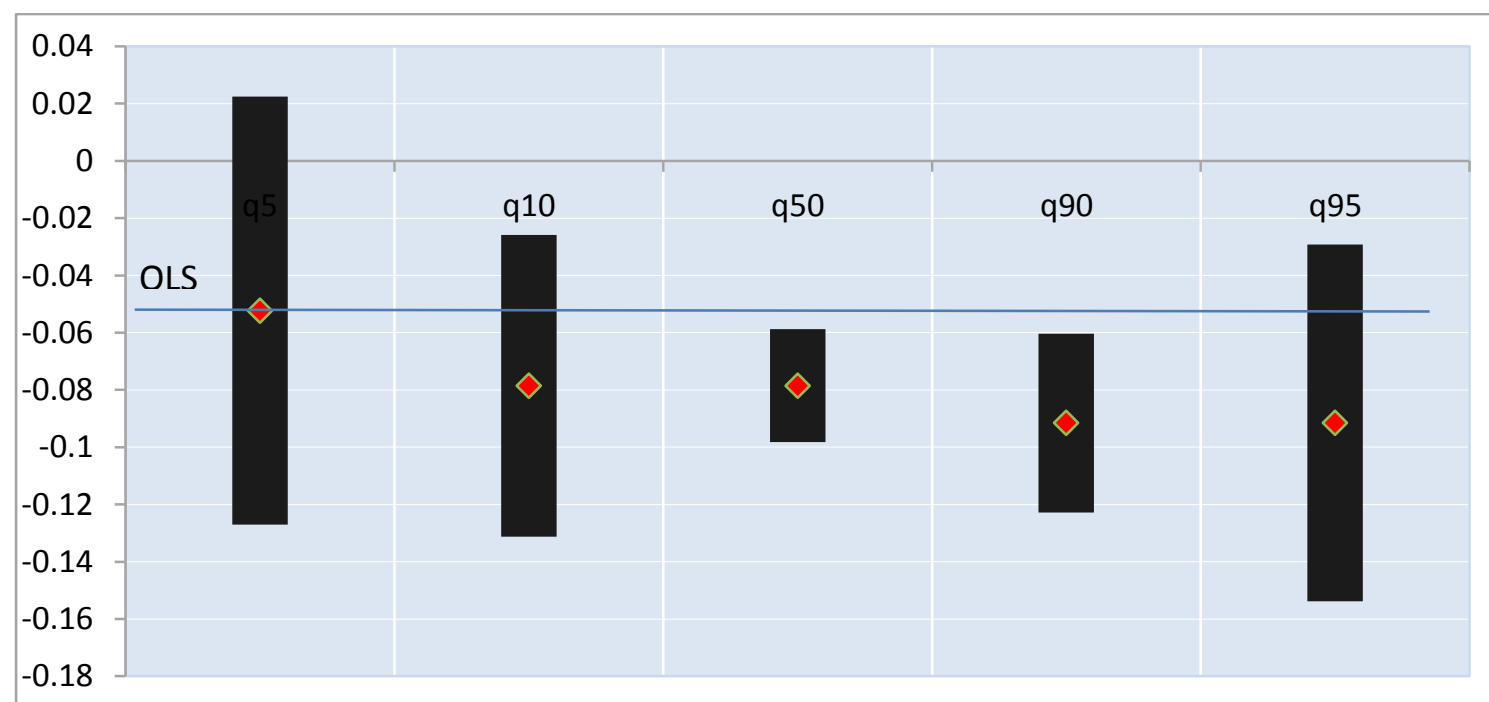

Note: The diamonds depict the point estimates and the thick bars a confidence interval of $+/-1$ standard deviation. The horizontal blue line depicts the OLS estimate. The estimates are based on the specification in the first panel of Table 5.

\section{External policies}

\section{Capital account openness}

Higher capital account openness (K_open) is generally negatively correlated with growth at the lower quantiles of the conditional GDP growth distributions (Table 6 and Figure 11). ${ }^{16}$ This result is confirmed when using instead a de facto measure of capital account openness (Fin_Open), measured as the sum of total external assets and liabilities in per cent of GDP. This suggests that greater capital account openness is associated with more severe negative growth shocks, i.e. it increases the negative GDP tail risk. This result is in line with the view that more open economies are exposed to higher financial and economic volatility (e.g. Bhagwati (1998), OECD, 2011). The result therefore suggest that in the sample considered in this paper a higher exposure to external shocks plays a more important role compared to the potentially dampening effect of financial openness on domestic shocks. The evidence on how higher capital account openness impacts growth at the top quantiles and the median is rather inconclusive across specifications. ${ }^{17}$

16. For details on the data used in this section see Table A2.5 in Appendix 2.

17. Some preliminary tests were run to investigate whether the composition of capital flows matter, but the results were inconclusive. 
Figure 11. The relationship between capital account openness and GDP tail risk

Effect on GDP growth (q-on-q) of increasing capital account openness by one standard deviation, by quantile

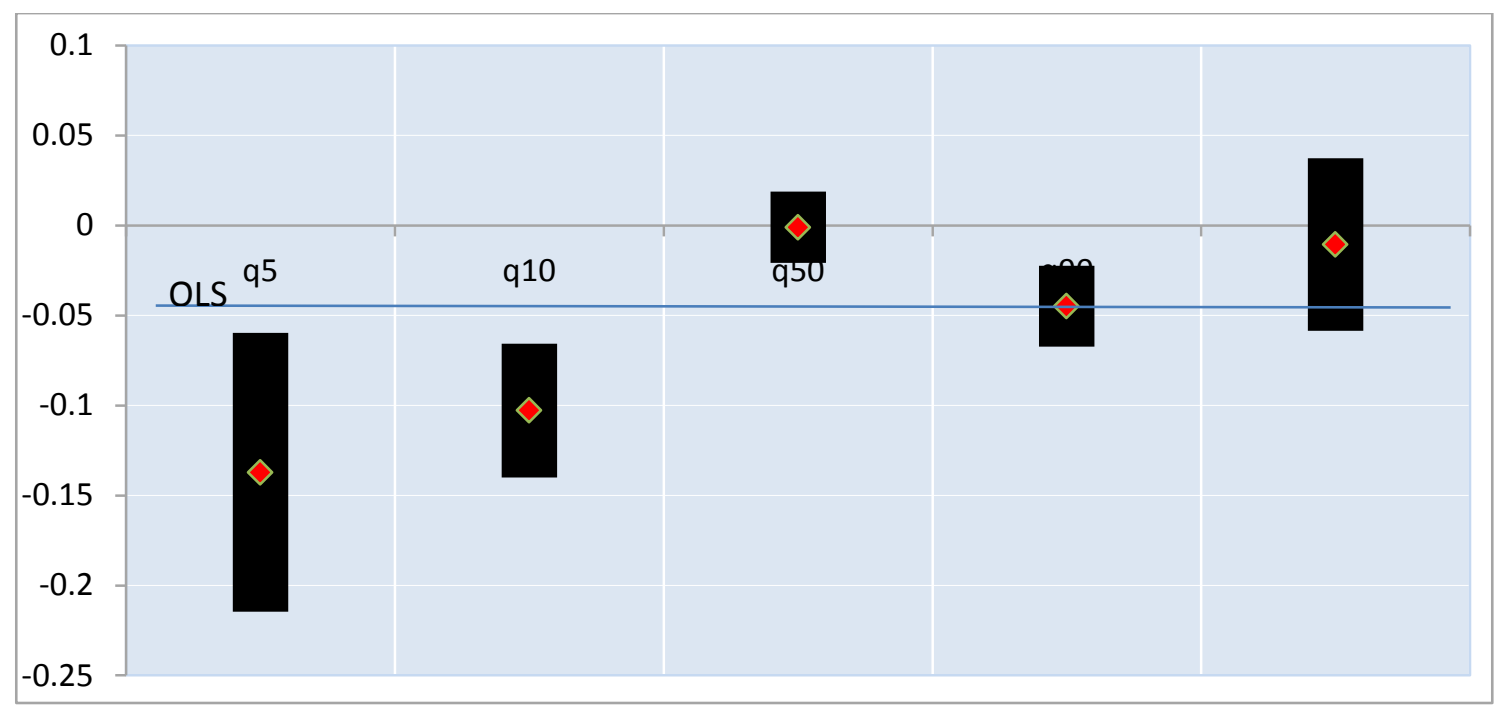

Note: The diamonds depict the point estimates and the thick bars a confidence interval of $+/-1$ standard deviation. The horizontal blue line depicts the OLS estimate. The estimates are based on the specification in the first panel of Table 6.

\section{International reserves}

There is relatively robust evidence across specifications that greater foreign exchange reserves are positively correlated with the lower quantiles of the conditional GDP growth distributions (Table 6 and Figure 12). This suggests that greater reserves are associated with less negative growth shocks, i.e. they reduce the negative GDP tail risk. The coefficients on the lower quantiles suggest that an increase of foreign exchange reserves by one standard deviation (about 8 percentage points of GDP in our sample) increases quarterly growth in the lower tail by about $0.15-0.25$ percentage points (Figure 12). Overall, this evidence is in line with studies which highlight the role of reserves for buffering external shocks and containing macroeconomic volatility (Obstfeld et al. 2010). For instance, international reserves represent a macro prudential tool able to cushion the risk of exchange rate volatility and reduce the economic impact of sudden stops in capital flows. ${ }^{18}$ The evidence on the median suggests a positive effect on growth and is corroborated by the OLS estimate which contrasts with the view that holding foreign reserves can be costly in normal times because their return is lower than the interest rate offered on domestic government debt. The evidence on the upper quantiles is rather inconclusive across specifications.

18. As an example, the accumulation of foreign reserves by emerging economies following the Asian currency crises of the late 1990s served two purposes (Gourichas and Obstfeld, 2011). First, it slowed down the appreciation of the domestic currency during the pre-crisis expansionary period; and second, it served as a self-insurance mechanism during the crisis, deterring currency and banking panics. By eliminating concerns about debt roll over difficulties, it gave investors less incentives to attack domestic currencies. International reserves also gave central banks room to counteract the depreciation of currencies during crisis. 
Figure 12. The relationship between foreign exchange reserves and GDP tail risk

Effect on GDP growth (q-on-q) of increasing foreign exchange reserves by one standard deviation, by quantile

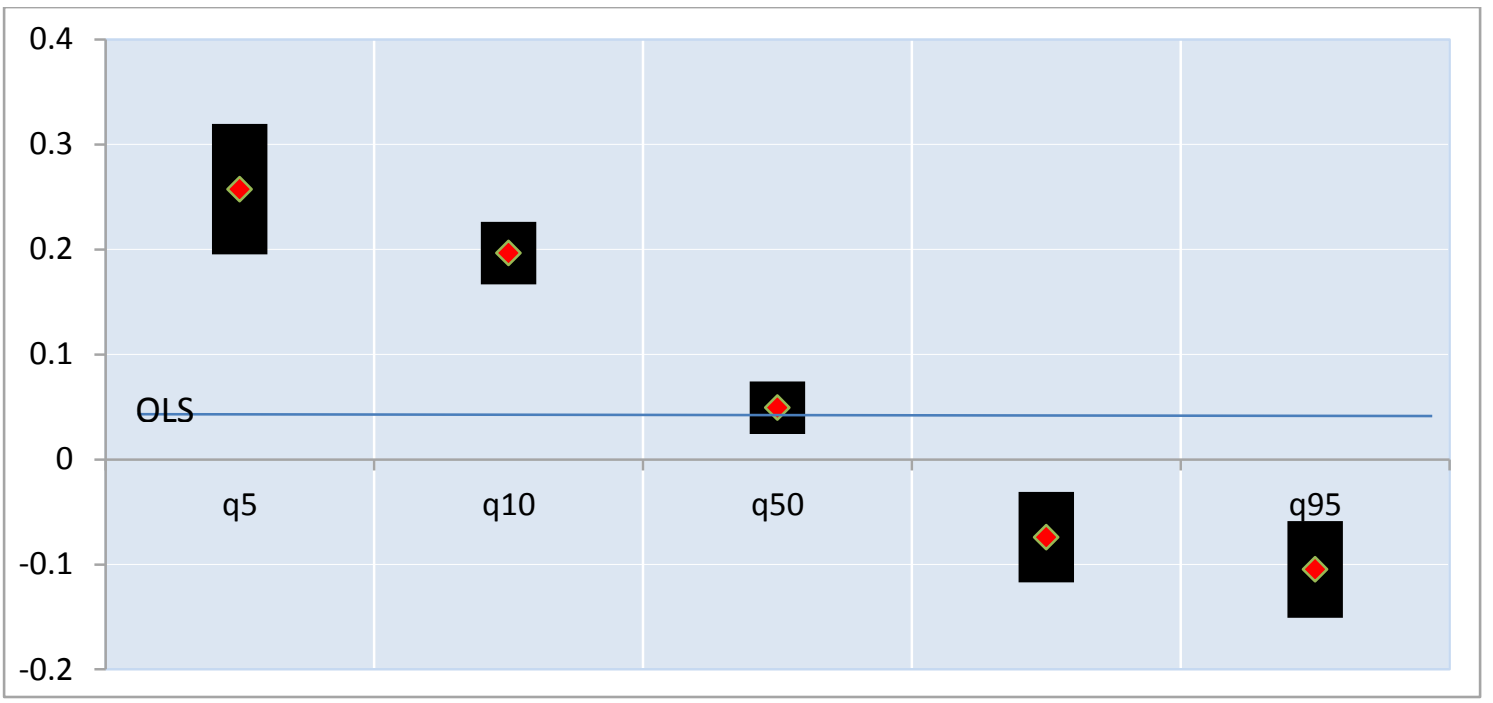

Note: The diamonds depict the point estimates and the thick bars a confidence interval of $+/-1$ standard deviation. The horizontal blue line depicts the OLS estimate. The estimates are based on the specification in the first panel of Table 6.

\section{Exchange rate regime}

The evidence suggest that more flexible exchange rates tend to be associated with larger positive growth shocks, as shown by the generally positive coefficients on the top quantiles of the conditional growth distribution. The coefficient at the median, as well as the OLS estimate, suggests a positive association between growth and more flexible exchange rates on average. Results are inconclusive regarding how the exchange rate regime affects the bottom quantiles (Table 6).

\section{Other policies}

Unreported results include additional explorations of the impact of policies such as product market regulation (measured by the OECD indicators on regulation in energy, transport and communication, ETCR), the cost of bankruptcy procedures, the tax wedge between labour cost and take-home pay, the trade union density rate and housing regulations (measured by transaction costs in property markets). These results were generally inconclusive in the sense that signs and significance of the coefficients changed across specifications. However, this does not mean that such policies are irrelevant for GDP tail risks, as it could instead reflect data limitations.

\section{Conclusions}

This paper has investigated how policy settings are related to GDP tail risks. Quantile regression methods, a novel technique in the field of macroeconomics, are used to gain a better understanding of the type of policy frameworks that are associated with more severe negative growth shocks and the frameworks that may lead to more extreme positive growth shocks. Table 7 provides an overview of the empirical results on how policies are related to GDP tail risks for a panel of mostly OECD countries when conditioning on macroeconomic policies and several country characteristics such as the size, stage of development and openness to trade. 
The results point at some possible trade-offs between the role of policies in mitigating GDP tail risks and in boosting growth. First, countries with larger automatic stabilisers experience less negative growth shocks and smaller positive growth shocks. At the same time, larger automatic stabilisers have a negative effect on median growth pointing at a possible trade-off between growth and stabilisation.

Second, recent evidence suggests that macroprudential policies have benefits, as they help manage financial cycles and can decrease the probability that credit and asset booms end up badly (Cerutti et al. 2015; Dell'Ariccia et al. 2012). Our results are consistent with that view, given that greater use of macroprudential policies is associated with less extreme positive growth shocks. However, the results in this paper also suggest that the use of macroprudential policies may be associated with lower growth on average. Given that macroprudential policies are relatively new tools more experience and evidence will be needed to confirm this finding.

In future work it would be interesting to further shed light on a number of issues that the results of this paper uncover. First, to the extent that better institutional quality is associated with less negative growth shocks in future work it would be interesting to dig deeper and get a better understanding of which other features of institutions could matter for GDP tail risks. For instance, one could imagine that the type of institutional set-up of financial supervision existing in a country or the crisis management procedures in place could play a role for GDP tail risks as well.

Second, countries with more effective prudential banking supervision seem to experience less severe negative growth shocks. But good banking supervision might not be enough to mitigate negative GDP tail risks. It would be interesting to assess the role of supervision in other parts of the financial system, such as supervision of non-bank financial institutions for GDP tail risks. In addition, a drawback of the data on financial liberalisation is that it only extends to 2005 and thus does not include the global financial crisis. It would therefore be interesting to investigate in the future if the results also hold when the global financial crisis is included in the sample.

Finally, while the role of housing market policies on GDP tail risks was assessed, the results were inconclusive possibly because of lack of time variation in these indicators. In the future it would be interesting to update the OECD housing policy indicators and assess how housing market policies affect GDP tails risks. Boom-bust cycles in housing markets can have important implications for both macroeconomic and financial stability and in turn, housing market cycles are closely linked to housing market policies. 


\section{Results tables}

Table 1. Results: controls

\begin{tabular}{|c|c|c|c|c|c|c|}
\hline & \multicolumn{6}{|c|}{ Dependent variable: GDP arowth (demeaned) } \\
\hline & q5 & $q 10$ & q50 & q90 & q95 & OLS \\
\hline Real GDP p.c. (log) & $\begin{array}{l}-0.04 \\
(-0.84)\end{array}$ & $\begin{array}{l}-0.04^{\star} \\
(-1.94)\end{array}$ & $\begin{array}{l}-0.02^{\star} \\
(-1.91)\end{array}$ & $\begin{array}{l}-0.00 \\
(-0.19)\end{array}$ & $\begin{array}{l}-0.00 \\
(-0.08)\end{array}$ & $\begin{array}{l}-0.02^{*} \\
(-1.79)\end{array}$ \\
\hline Population (log) & $\begin{array}{l}0.38^{\star \star \star} \\
(6.18) \S\end{array}$ & $\begin{array}{l}0.25^{\star \star \star} \\
(7.24) \S\end{array}$ & $\begin{array}{l}-0.06^{\star \star \star} \\
(-3.44)\end{array}$ & $\begin{array}{c}-0.39^{\star \star \star} \\
(-11.4) \S\end{array}$ & $\begin{array}{l}-0.53^{\star \star \star} \\
(-13.03) \S\end{array}$ & $\begin{array}{l}-0.07^{\star \star \star} \\
(-3.52)\end{array}$ \\
\hline Trade openness & $\begin{array}{l}0.17 \\
(0.71)\end{array}$ & $\begin{array}{l}0.17^{\star} \\
(1.88) \S\end{array}$ & $\begin{array}{l}-0.00 \\
(0.03)\end{array}$ & $\begin{array}{l}-0.39^{\star \star \star} \\
(-3.76) \S\end{array}$ & $\begin{array}{l}-0.59^{\star \star \star} \\
(-5.32) \S\end{array}$ & $\begin{array}{l}-0.09^{\star} \\
(-1.65)\end{array}$ \\
\hline Government revenues in $\%$ of GDP & $\begin{array}{l}0.03^{\star \star \star} \\
(3.41) \S\end{array}$ & $\begin{array}{l}0.02^{\star \star \star} \\
(326) \S\end{array}$ & $\begin{array}{l}-0.01^{\star \star \star} \\
(-3.55) \S\end{array}$ & $\begin{array}{l}-0.04^{\star \star \star} \\
(-8.8) \S\end{array}$ & $\begin{array}{l}-0.05^{\star \star \star} \\
(-10.01) \delta\end{array}$ & $\begin{array}{l}-0.01^{\star \star} \\
(-2.1)\end{array}$ \\
\hline Real short term interest rate & $\begin{array}{l}-0.03 \\
(-1.52) \S\end{array}$ & $\begin{array}{l}-0.04^{\star \star \star} \\
(-2.97) \S\end{array}$ & $\begin{array}{l}0.01 \\
(0.85)\end{array}$ & $\begin{array}{l}0.01 \\
(0.54)\end{array}$ & $\begin{array}{l}0.01 \\
(0.8)\end{array}$ & $\begin{array}{l}-0.01^{\star \star} \\
(-2.52)\end{array}$ \\
\hline Frequency & & & & & & \\
\hline Fixed effects & & & & 10 & & \\
\hline \# of observation & & & & & & \\
\hline \# of countries & & & & 4 & & \\
\hline
\end{tabular}

Note: ${ }^{*}, * *,{ }^{* * *}$ signify coefficients significant at the 10,5 and $1 \%$ level respectively. T-values in parenthesis are based on bootstrapped standard errors. Coefficient significantly different from zero at the 10,5 or $1 \%$ level are bolded. . § signifies that the coefficient is significantly different from the median coefficient at least at the $10 \%$ level. 
Table 2. Results: financial market characteristics

ECO/WKP(2016)63

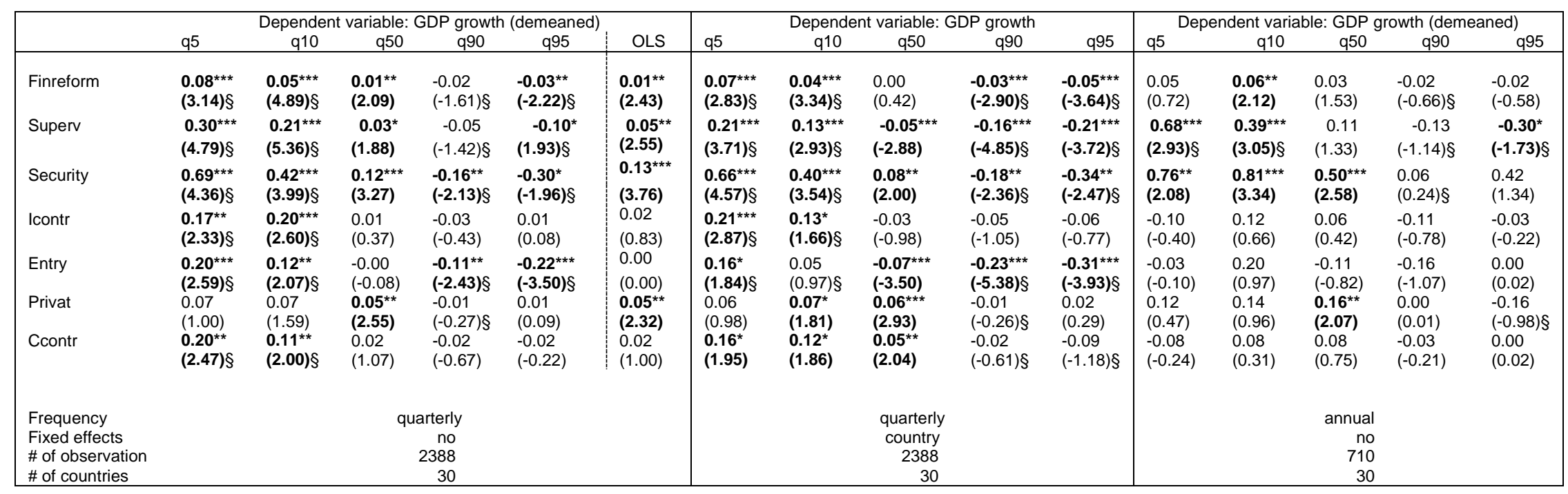

Note: Each regression includes only one financial market variable at a time and includes the following control variables which are not reported: population (log), GDP p.c. (log), trade openness, government revenues in $\%$ of GDP; real short-term interest rate. ****** signify coefficients significant at the 10,5 and $1 \%$ level respectively. T-values in parenthesis are based on bootstrapped standard errors. Coefficient significantly different from zero at the 10,5 or $1 \%$ level are bolded. $\S$ signifies that the coefficient is significantly different from the median coefficient at least at the $10 \%$ level. 
Table 3. Results: macroprudential policies

\begin{tabular}{|c|c|c|c|c|c|c|c|c|c|c|c|c|c|c|c|c|}
\hline & \multicolumn{6}{|c|}{ Dependent variable: GDP growth (demeaned) } & \multirow{2}{*}{\multicolumn{5}{|c|}{$\begin{array}{l}\text { Dependent variable: GDP growth } \\
\mathrm{q} 10 \quad \mathrm{q} 50\end{array}$}} & \multirow{2}{*}{\multicolumn{5}{|c|}{$\begin{array}{l}\text { Dependent variable: GDP growth (demeaned) } \\
\text { q10 } 950 \quad \text { q90 } 95 \text { (a) }\end{array}$}} \\
\hline & q5 & q10 & q50 & q90 & q95 & OLS & & & & & & & & & & \\
\hline $\mathrm{MPI}$ & $\begin{array}{l}0.12 \\
(1.18) \S\end{array}$ & $\begin{array}{l}-0.01 \\
(-0.17)\end{array}$ & $\begin{array}{l}-0.06^{* * *} \\
(-3.57)\end{array}$ & $\begin{array}{l}-0.07^{*} \\
(-1.82)\end{array}$ & $\begin{array}{l}-0.1^{\star \star *} \\
(-2.77)\end{array}$ & $\begin{array}{l}-0.06^{* *} \\
(-2.16)\end{array}$ & $\begin{array}{l}0.04 \\
(0.32)\end{array}$ & $\begin{array}{l}-0.02 \\
(-0.50)\end{array}$ & $\begin{array}{l}-0.05^{* * *} \\
(-311)\end{array}$ & $\begin{array}{l}-0.08^{* *} \\
(-2.38)\end{array}$ & $\begin{array}{l}-0.11^{* * *} \\
-(-3.26) 8\end{array}$ & $\begin{array}{l}0.58^{*} \\
(1.77) 8\end{array}$ & $\begin{array}{l}-0.01 \\
-0.03)\end{array}$ & $\begin{array}{l}-0.17 \\
(-1.53)\end{array}$ & $\begin{array}{l}-0.43^{* * *} \\
-(-3.35) \S\end{array}$ & $\begin{array}{l}-0.42^{* *} \\
-(-2.47)\end{array}$ \\
\hline BORROWER & $\begin{array}{l}0.12 \\
(0.69)\end{array}$ & $\begin{array}{l}0.13 \\
(1.15) \S\end{array}$ & $\begin{array}{l}-0.08^{\star} \\
(-1.94)\end{array}$ & $\begin{array}{l}-0.26^{\star \star \star} \\
(-4.00) \S\end{array}$ & $\begin{array}{l}-0.25^{\star \star \star} \\
(-3.16) \S\end{array}$ & $\begin{array}{l}-0.14^{\star \star} \\
(-2.41)\end{array}$ & $\begin{array}{l}0.17 \\
(1.03)\end{array}$ & $\begin{array}{l}0.1 \\
(1.06) \S\end{array}$ & $\begin{array}{l}-0.11^{\star \star \star} \\
(-3.30)\end{array}$ & $\begin{array}{l}-0.21^{\star \star \star} \\
(-3.12) \S\end{array}$ & $\begin{array}{l}-0.30^{\star \star \star} \\
(-4.05) \S\end{array}$ & $\begin{array}{l}0.32 \\
(0.39)\end{array}$ & $\begin{array}{l}-0.59 \\
(-0.91)\end{array}$ & $\begin{array}{l}-0.37 \\
(-1.23)\end{array}$ & $\begin{array}{l}-0.8^{\star \star \star} \\
(-2.86)\end{array}$ & $\begin{array}{l}-0.93^{\star \star \star} \\
(-3.37)\end{array}$ \\
\hline FINANCIAL & $\begin{array}{l}0.06 \\
(0.44)\end{array}$ & $\begin{array}{l}-0.06 \\
(-0.79)\end{array}$ & $\begin{array}{l}-0.06^{\star \star \star} \\
(-2.79)\end{array}$ & $\begin{array}{l}-0.04 \\
(-0.85)\end{array}$ & $\begin{array}{l}-0.06 \\
(-1.09)\end{array}$ & $\begin{array}{l}-0.04 \\
(-1.24)\end{array}$ & $\begin{array}{l}-0.02 \\
(-0.17)\end{array}$ & $\begin{array}{l}-0.08 \\
(-1.60)\end{array}$ & $\begin{array}{l}-0.03 \\
(-1.28)\end{array}$ & $\begin{array}{l}-0.06 \\
(-1.20)\end{array}$ & $\begin{array}{l}-0.07 \\
(-1.11)\end{array}$ & $\begin{array}{l}0.89^{\star} \\
(1.91) \S\end{array}$ & $\begin{array}{l}0.31 \\
(0.66)\end{array}$ & $\begin{array}{l}-0.17 \\
(-1.30)\end{array}$ & $\begin{array}{c}-0.59^{\star \star \star} \\
(-2.77) \S\end{array}$ & $\begin{array}{l}-0.23 \\
(-0.75)\end{array}$ \\
\hline LTV & $\begin{array}{l}-0.25 \\
(-1.21)\end{array}$ & $\begin{array}{l}-0.25^{\star} \\
(-1.91)\end{array}$ & $\begin{array}{l}-0.19^{\star \star \star} \\
(-3.44)\end{array}$ & $\begin{array}{c}-0.15^{\star} \\
(-1.76)\end{array}$ & $\begin{array}{c}-0.22^{\star \star} \\
(-2.17)\end{array}$ & $\begin{array}{l}-0.26^{\star \star \star} \\
(-3.53)\end{array}$ & $\begin{array}{c}-0.60^{\star \star} \\
(-2.53)\end{array}$ & $\begin{array}{l}-0.38^{\star \star \star} \\
(-3.20)\end{array}$ & $\begin{array}{l}-0.26^{\star \star \star} \\
(-5.21)\end{array}$ & $\begin{array}{l}-0.26^{\star \star \star} \\
(-3.67)\end{array}$ & $\begin{array}{l}-0.43^{\star \star \star *} \\
(-3.72)\end{array}$ & $\begin{array}{l}-0.34 \\
(-0.31)\end{array}$ & $\begin{array}{l}-1.61^{\star} \\
(-1.88)\end{array}$ & $\begin{array}{l}-0.76^{\star} \\
(-1.90)\end{array}$ & $\begin{array}{l}-0.84^{\star \star} \\
(-2.17)\end{array}$ & $\begin{array}{l}-0.93 \\
(-1.36)\end{array}$ \\
\hline LTV_CAP & $\begin{array}{l}0.05 \\
(0.24)\end{array}$ & $\begin{array}{l}0.02 \\
(0.13)\end{array}$ & $\begin{array}{l}-0.14^{\star \star} \\
(-2.11)\end{array}$ & $\begin{array}{l}-0.41^{\star \star \star} \\
(-5.55) \S\end{array}$ & $\begin{array}{l}-0.48^{\star \star \star} \\
(-5.15) \S\end{array}$ & $\begin{array}{l}-0.23^{\star \star \star} \\
(-2.79)\end{array}$ & $\begin{array}{l}-0.10 \\
(-0.40)\end{array}$ & $\begin{array}{l}-0.12 \\
(-1.08)\end{array}$ & $\begin{array}{l}-0.31^{\star \star \star} \\
(-5.14)\end{array}$ & $\begin{array}{l}-0.40^{\star \star \star} \\
(-4.45)\end{array}$ & $\begin{array}{l}-0.58^{\star \star \star \star} \\
(-8.17) \S\end{array}$ & $\begin{array}{l}0.34 \\
(0.25)\end{array}$ & $\begin{array}{l}-1.21 \\
(-1.02)\end{array}$ & $\begin{array}{l}-0.6 \\
(-1.36)\end{array}$ & $\begin{array}{l}-1.16^{\star \star \star} \\
(-2.79)\end{array}$ & $\begin{array}{l}-1.01^{\star \star} \\
(-2.47)\end{array}$ \\
\hline DTI & $\begin{array}{l}0.68^{\star \star} \\
(2.02) \S\end{array}$ & $\begin{array}{l}0.42^{\star \star} \\
(2.55) \S\end{array}$ & $\begin{array}{l}-0.09 \\
(-0.92)\end{array}$ & $\begin{array}{l}-0.32^{\star \star} \\
(-2.57)\end{array}$ & $\begin{array}{l}-0.35^{\star \star \star \star} \\
(-2.70) \S\end{array}$ & $\begin{array}{l}-0.14 \\
(-1.12)\end{array}$ & $\begin{array}{l}0.44 \\
(1.47) \S\end{array}$ & $\begin{array}{l}0.54^{\star \star \star} \\
(2.67) \S\end{array}$ & $\begin{array}{l}-0.08 \\
(-1.30)\end{array}$ & $\begin{array}{l}-0.26^{\star \star} \\
(-2.21)\end{array}$ & $\begin{array}{l}-0.48^{\star \star \star \star} \\
(-2.77) \S\end{array}$ & $\begin{array}{l}0.87 \\
(0.40)\end{array}$ & $\begin{array}{l}-0.03 \\
(-0.02)\end{array}$ & $\begin{array}{l}-0.57 \\
(-1.12)\end{array}$ & $\begin{array}{l}-1.3^{\star \star} \\
(-2.21)\end{array}$ & $\begin{array}{l}-1.85^{\star \star \star} \\
(-2.88) \S\end{array}$ \\
\hline$D P^{\text {a) }}$ & $\begin{array}{l}0.09 \\
(0.45)\end{array}$ & $\begin{array}{l}-0.31^{\star} \\
(-1.96)\end{array}$ & $\begin{array}{l}-0.13 \\
(-1.16)\end{array}$ & $\begin{array}{c}-0.42^{\star \star \star} \\
(-6.60) \S\end{array}$ & $\begin{array}{c}-0.66^{\star \star \star} \\
(-8.18) \S\end{array}$ & $\begin{array}{l}-0.26 \\
(-1.44)\end{array}$ & & & & & & $\begin{array}{l}0.34 \\
(0.33)\end{array}$ & $\begin{array}{l}-1.85 \\
(-1.28)\end{array}$ & $\begin{array}{l}-1.16 \\
(-0.98)\end{array}$ & $\begin{array}{l}-0.36 \\
(-1.01)\end{array}$ & $\begin{array}{l}-0.79^{\star \star} \\
(-2.11)\end{array}$ \\
\hline CTC & $\begin{array}{l}1.81^{\star \star \star \star} \\
(5.88) \S\end{array}$ & $\begin{array}{l}1.20^{\star \star \star} \\
(5.73) \S\end{array}$ & $\begin{array}{l}0.05 \\
(0.32)\end{array}$ & $\begin{array}{l}-0.47^{\star} \\
(-1.91) \S\end{array}$ & $\begin{array}{c}-0.99^{\star \star \star *} \\
(-4.57) \S\end{array}$ & $\begin{array}{l}0.17 \\
(0.37)\end{array}$ & $\begin{array}{l}1.59^{\star \star \star} \\
(6.37) \S\end{array}$ & $\begin{array}{l}1.08^{\star \star \star} \\
(5.14) \S\end{array}$ & $\begin{array}{l}0.27 \\
(1.36)\end{array}$ & $\begin{array}{c}-0.48^{\star * *} \\
(-2.62) \S\end{array}$ & $\begin{array}{l}-1.07 * \star \\
(-5.68) \S\end{array}$ & $\begin{array}{l}4.84^{\star \star \star} \\
(3.29) \S\end{array}$ & $\begin{array}{l}4.87^{\star \star \star} \\
(5.28) \S\end{array}$ & $\begin{array}{l}0.19 \\
(0.53)\end{array}$ & $\begin{array}{c}-2.21^{\star \star \star} \\
(-4.13) \S\end{array}$ & $\begin{array}{l}-3.07^{\star \star \star} \\
(-4.58) \S\end{array}$ \\
\hline LEV & $\begin{array}{l}0.08 \\
(0.26)\end{array}$ & $\begin{array}{l}0.14 \\
(0.61)\end{array}$ & $\begin{array}{l}0.08 \\
(1.53)\end{array}$ & $\begin{array}{l}0.11 \\
(1.00)\end{array}$ & $\begin{array}{l}0.21 \\
(1.26)\end{array}$ & $\begin{array}{l}0.07 \\
(0.58)\end{array}$ & $\begin{array}{l}0.04 \\
(0.14)\end{array}$ & $\begin{array}{l}0.12 \\
(0.56)\end{array}$ & $\begin{array}{l}0.21^{\star \star \star \star} \\
(3.73)\end{array}$ & $\begin{array}{l}0.15 \\
(1.19)\end{array}$ & $\begin{array}{l}0.3^{*} \\
(1.67)\end{array}$ & $\begin{array}{l}2.08 \\
(1.48)\end{array}$ & $\begin{array}{l}2.59^{*} \\
(1.94) \S\end{array}$ & $\begin{array}{l}0.07 \\
(0.23)\end{array}$ & $\begin{array}{l}-0.51 \\
(-0.77)\end{array}$ & $\begin{array}{l}0.64 \\
(0.79)\end{array}$ \\
\hline SIFI & $\begin{array}{l}1.25^{\star \star \star} \\
(4.57) \S\end{array}$ & $\begin{array}{l}0.62^{\star \star \star} \\
(2.64) \S\end{array}$ & $\begin{array}{l}-0.26 \\
(-1.13)\end{array}$ & $\begin{array}{l}-0.93^{\star \star \star} \\
(-6.04) \S\end{array}$ & $\begin{array}{l}-1.31^{\star \star \star *} \\
(-10.00) \S\end{array}$ & $\begin{array}{l}-0.1 \\
(-0.26)\end{array}$ & $\begin{array}{l}1.33^{\star \star \star \star} \\
(5.30) \S\end{array}$ & $\begin{array}{l}0.92^{\star \star \star \star} \\
(3.18) \S\end{array}$ & $\begin{array}{l}0.02 \\
(0.08)\end{array}$ & $\begin{array}{l}-0.73^{\star \star \star} \\
(-4.30) \S\end{array}$ & $\begin{array}{l}-1.21^{\star \star \star} \\
(-7.08) \S\end{array}$ & $\begin{array}{l}4.66^{\star \star \star} \\
(3.93) \S\end{array}$ & $\begin{array}{l}2.89^{\star \star \star \star} \\
(2.88) \S\end{array}$ & $\begin{array}{l}-1.12 \\
(-1.51)\end{array}$ & $\begin{array}{c}-2.89^{\star \star \star \star} \\
(-4.32) \S\end{array}$ & $\begin{array}{l}-4.04^{\star \star \star} \\
(-6.44) \S\end{array}$ \\
\hline INTER & $\begin{array}{l}-0.10 \\
(-0.39)\end{array}$ & $\begin{array}{l}-0.12 \\
(-0.65)\end{array}$ & $\begin{array}{l}-0.1^{\star} \\
(-1.93)\end{array}$ & $\begin{array}{l}-0.2^{\star \star} \\
(-2.23)\end{array}$ & $\begin{array}{l}-0.31^{\star *} \\
(-2.26) \S\end{array}$ & $\begin{array}{l}-0.08 \\
(-0.87)\end{array}$ & $\begin{array}{l}-0.28 \\
(-1.27)\end{array}$ & $\begin{array}{l}-0.11 \\
(-0.88)\end{array}$ & $\begin{array}{l}-0.04 \\
(-0.75)\end{array}$ & $\begin{array}{l}-0.18^{\star} \\
(-1.93) \S\end{array}$ & $\begin{array}{l}-0.28^{*} \\
(-1.86) \S\end{array}$ & $\begin{array}{l}1.44 \\
(1.02)\end{array}$ & $\begin{array}{l}1.22 \\
(1.10)\end{array}$ & $\begin{array}{l}-0.21 \\
(-0.70)\end{array}$ & $\begin{array}{l}-0.8 \\
(-1.63)\end{array}$ & $\begin{array}{l}-1.19^{\star} \\
(-1.68)\end{array}$ \\
\hline CONC & $\begin{array}{l}0.11 \\
(0.42)\end{array}$ & $\begin{array}{l}-0.07 \\
(-0.47)\end{array}$ & $\begin{array}{l}-0.01 \\
(-0.16)\end{array}$ & $\begin{array}{l}0.09 \\
(1.21)\end{array}$ & $\begin{array}{l}0.10 \\
(0.92)\end{array}$ & $\begin{array}{l}0.04 \\
(0.60)\end{array}$ & $\begin{array}{l}0.17 \\
(0.74)\end{array}$ & $\begin{array}{l}0.00 \\
(0.02) \S\end{array}$ & $\begin{array}{l}0.13^{\star \star \star *} \\
(2.75)\end{array}$ & $\begin{array}{l}0.15^{\star \star} \\
(2.16)\end{array}$ & $\begin{array}{l}0.07 \\
(0.53)\end{array}$ & $\begin{array}{l}1.62^{\star} \\
(1.95)\end{array}$ & $\begin{array}{l}0.62 \\
(0.74)\end{array}$ & $\begin{array}{l}0.07 \\
(0.22)\end{array}$ & $\begin{array}{l}-0.28 \\
(-0.73)\end{array}$ & $\begin{array}{l}-0.09 \\
(-0.16)\end{array}$ \\
\hline FC & $\begin{array}{l}-0.86 \\
(-0.83)\end{array}$ & $\begin{array}{l}-0.71 \\
(-1.57)\end{array}$ & $\begin{array}{l}-0.55^{\star \star \star} \\
(-4.36)\end{array}$ & $\begin{array}{l}0.65^{\star} \\
(1.92) \S\end{array}$ & $\begin{array}{l}0.45 \\
(0.71)\end{array}$ & $\begin{array}{l}-0.4^{\star \star} \\
(-2.5)\end{array}$ & $\begin{array}{l}-1.06 \\
(-0.98)\end{array}$ & $\begin{array}{l}-0.68 \\
(-1.09)\end{array}$ & $\begin{array}{l}-0.21^{\star} \\
(-1.89)\end{array}$ & $\begin{array}{l}0.63 \\
(1.46) \S\end{array}$ & $\begin{array}{l}0.66 \\
(1.01)\end{array}$ & $\begin{array}{l}1.16 \\
(0.43)\end{array}$ & $\begin{array}{l}-2.60 \\
-1.50)\end{array}$ & $\begin{array}{l}-1.80^{\star \star \star \star} \\
(-3.13)\end{array}$ & $\begin{array}{l}-1.46 \\
(-1.18)\end{array}$ & $\begin{array}{l}-0.31 \\
(-0.16)\end{array}$ \\
\hline $\mathrm{RR}^{\text {a) }}$ & $\begin{array}{l}-0.43 \\
(-0.82)\end{array}$ & $\begin{array}{l}-0.32 \\
(-1.16) \S\end{array}$ & $\begin{array}{l}0.18^{\star} \\
(1.88)\end{array}$ & $\begin{array}{l}0.49^{\star \star \star} \\
(4.09) \S\end{array}$ & $\begin{array}{l}0.43^{\star \star \star} \\
(2.95)\end{array}$ & $\begin{array}{l}0.13 \\
(0.7)\end{array}$ & & & & & & $\begin{array}{l}0.52 \\
(0.29)\end{array}$ & $\begin{array}{l}1.50 \\
(0.75)\end{array}$ & $\begin{array}{l}0.78^{\star} \\
(1.73)\end{array}$ & $\begin{array}{l}1.06 \\
(1.56)\end{array}$ & $\begin{array}{l}0.96 \\
(1.54)\end{array}$ \\
\hline TAX & $\begin{array}{l}0.42^{\star} \\
(1.72) \S\end{array}$ & $\begin{array}{l}0.01 \\
(0.05) \S\end{array}$ & $\begin{array}{l}-0.39^{\star * *} \\
(-5.44)\end{array}$ & $\begin{array}{l}-0.4^{\star \star \star \star} \\
(-3.70)\end{array}$ & $\begin{array}{l}-0.39^{* *} \\
(-2.50)\end{array}$ & $\begin{array}{l}-0.24^{\star \star} \\
(-2.04)\end{array}$ & $\begin{array}{l}0.21 \\
(0.72)\end{array}$ & $\begin{array}{l}0.12 \\
(1.13) \S\end{array}$ & $\begin{array}{c}-0.16^{\star *} \\
(-2.18)\end{array}$ & $\begin{array}{l}-0.28^{\star *} \\
(-2.09)\end{array}$ & $\begin{array}{l}-0.33^{\star *} \\
(-2.47)\end{array}$ & $\begin{array}{l}1.18 \\
(1.08) \S\end{array}$ & $\begin{array}{l}-0.58 \\
(-0.59)\end{array}$ & $\begin{array}{l}-1.82^{\star * \star} \\
(-5.49)\end{array}$ & $\begin{array}{l}-2.13^{\star \star \star} \\
(-2.73)\end{array}$ & $\begin{array}{l}-2.53^{\star \star} \\
(-2.33)\end{array}$ \\
\hline $\begin{array}{l}\text { Frequency } \\
\text { Fixed effects }\end{array}$ & \multicolumn{6}{|c|}{$\begin{array}{c}\text { quarterly } \\
\text { no }\end{array}$} & \multicolumn{5}{|c|}{$\begin{array}{l}\text { quarterly } \\
\text { country }\end{array}$} & \multicolumn{5}{|c|}{$\begin{array}{r}\text { annual } \\
\text { no }\end{array}$} \\
\hline $\begin{array}{l}\text { \# of } \\
\text { observation }\end{array}$ & \multirow{2}{*}{\multicolumn{6}{|c|}{1700}} & \multirow{2}{*}{\multicolumn{5}{|c|}{1700}} & \multicolumn{5}{|c|}{425} \\
\hline \# of countries & & & & & & 31 & & & & & & \multicolumn{5}{|c|}{31} \\
\hline
\end{tabular}

Note: Each regression includes only one macroprudential policy variable at a time and includes the following control variables which are not reported: population (log), GDP p.c. (log), trade openness, government revenues in \% of GDP; real short-term interest rate. ${ }^{*},{ }^{* *},{ }^{* * *}$ signify coefficients significant at the 10,5 and $1 \%$ level respectively. T-values in parenthesis are based on bootstrapped standard errors. Coefficient significantly different from zero at the 10,5 or $1 \%$ level are bolded. § signifies that the coefficient is significantly different 
Table 4. Results: quality of institutions

ECO/WKP(2016)63

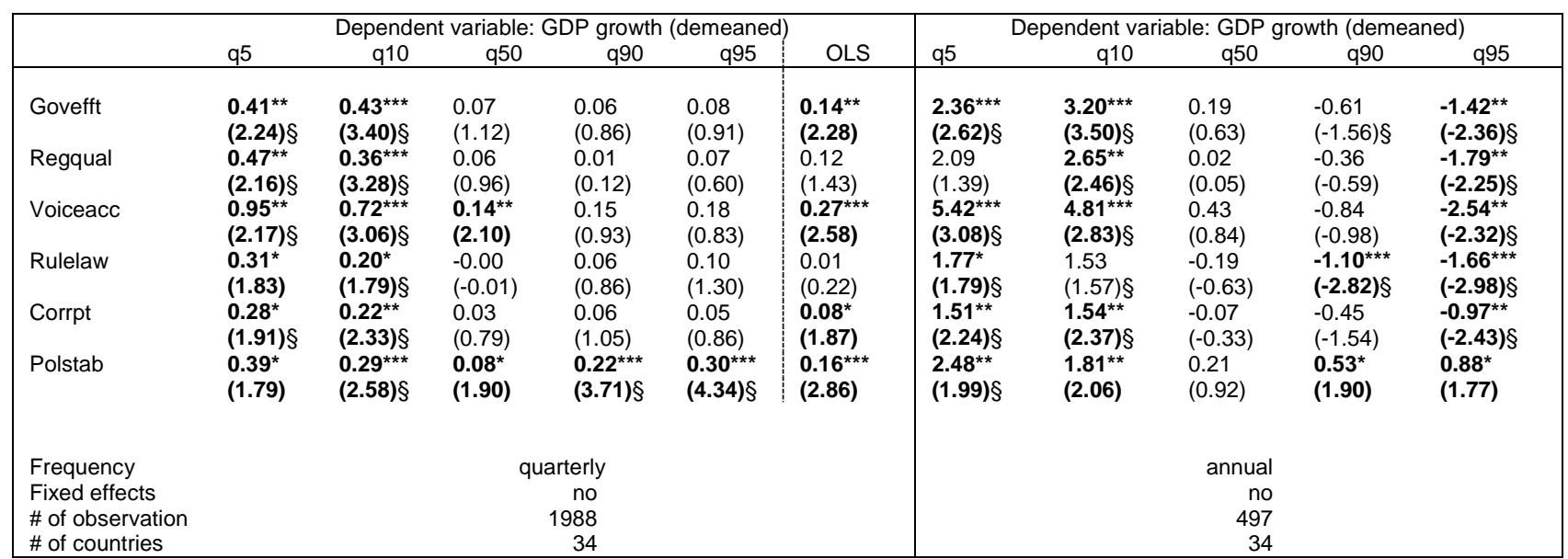

Note: Each regression includes only one institutional variable at a time and includes the following control variables which are not reported: population (log), GDP p.c. (log), trade openness, government revenues in \% of GDP; real short-term interest rate. ${ }^{*},{ }^{* *},{ }^{* * *}$ signify coefficients significant at the 10,5 and $1 \%$ level respectively. T-values in parenthesis are based on bootstrapped standard errors. Coefficient significantly different from zero at the 10,5 or $1 \%$ level are bolded. $\S$ signifies that the coefficient is significantly different from the median coefficient at least at the $10 \%$ level. 
Table 5. Results: labour market policies

\begin{tabular}{|c|c|c|c|c|c|c|c|c|c|c|c|c|c|c|c|c|}
\hline & \multicolumn{6}{|c|}{ Dependent variable: GDP growth (demeaned) } & \multicolumn{5}{|c|}{ Dependent variable: GDP growth } & \multicolumn{5}{|c|}{ Dependent variable: GDP growth (demeaned) } \\
\hline & q5 & q10 & $\mathrm{q} 50$ & q90 & q95 & OLS & q5 & $\mathrm{q} 10$ & q50 & q90 & q95 & q5 & $q 10$ & $\mathrm{q} 50$ & 990 & q95 \\
\hline ubgr_I ${ }^{1}$ & $\begin{array}{l}0.00 \\
(0.41)\end{array}$ & $\begin{array}{l}0.01 \\
(1.06)\end{array}$ & $\begin{array}{l}-0.00 \\
(-0.89)\end{array}$ & $\begin{array}{l}-0.01^{\star \star \star} \\
(-4.44) \S\end{array}$ & $\begin{array}{l}-0.02^{\star \star \star} \\
(-3.32) \S\end{array}$ & $\begin{array}{l}-0.00 \\
(-1.18)\end{array}$ & $\begin{array}{l}0.01 \\
(1.09)\end{array}$ & $\begin{array}{l}0.01 \\
(0.81)\end{array}$ & $\begin{array}{l}-0.00 \\
(-0.62)\end{array}$ & $\begin{array}{l}-0.01^{\star \star \star} \\
(-4.49) \S\end{array}$ & $\begin{array}{l}-0.01^{\star * \star} \\
(-2.90) \S\end{array}$ & \begin{tabular}{|l}
0.02 \\
$(0.76)$
\end{tabular} & $\begin{array}{l}0.02 \\
(1.25) \S\end{array}$ & $\begin{array}{l}-0.01 \\
(-1.26)\end{array}$ & $\begin{array}{l}-0.04^{\star \star *} \\
(-3.22)\end{array}$ & $\begin{array}{l}-0.04^{\star \star} \\
(-2.80)\end{array}$ \\
\hline \# of observation & \multirow{2}{*}{\multicolumn{6}{|c|}{$\begin{array}{c}1552 \\
29\end{array}$}} & \multirow{2}{*}{\multicolumn{5}{|c|}{$\begin{array}{c}1552 \\
29\end{array}$}} & \multicolumn{5}{|c|}{$\begin{array}{c}465 \\
29\end{array}$} \\
\hline \# of countries & & & & & & & & & & & & & & 29 & & \\
\hline almp_EXPPCT $100^{1}$ & $\begin{array}{l}0.20^{\star \star \star} \\
(2.81) \S\end{array}$ & $\begin{array}{l}0.06^{\star} \\
(1.68)\end{array}$ & $\begin{array}{l}0.01 \\
(0.38)\end{array}$ & $\begin{array}{l}-0.05^{\star \star} \\
(-2.05) \S\end{array}$ & $\begin{array}{l}-0.05^{\star} \\
(-1.82) \S\end{array}$ & $\begin{array}{l}0.03^{\star} \\
(1.74)\end{array}$ & $\begin{array}{l}0.33^{\star \star \star} \\
(6.51) \S\end{array}$ & $\begin{array}{l}0.27^{\star \star \star} \\
(8.67) \S\end{array}$ & $\begin{array}{l}0.18^{\star \star \star} \\
(12.37)\end{array}$ & $\begin{array}{l}0.13^{\star \star \star} \\
(8.16) \S\end{array}$ & $\begin{array}{l}0.08^{\star \star \star} \\
(2.75) \S\end{array}$ & $\begin{array}{l}0.49 \\
(1.60) \S\end{array}$ & $\begin{array}{l}0.14 \\
(0.66)\end{array}$ & $\begin{array}{l}-0.05 \\
(-0.53)\end{array}$ & $\begin{array}{l}-0.13 \\
(-1.35)\end{array}$ & $\begin{array}{l}-0.12 \\
(-1.02)\end{array}$ \\
\hline $\begin{array}{l}\text { \# of observation } \\
\text { \# of countries }\end{array}$ & \multicolumn{6}{|c|}{$\begin{array}{c}2506 \\
32\end{array}$} & \multicolumn{5}{|c|}{$\begin{array}{c}2506 \\
32\end{array}$} & \multicolumn{5}{|c|}{$\begin{array}{c}697 \\
32\end{array}$} \\
\hline $\min 2 \operatorname{med}^{2}$ & $\begin{array}{l}2.28^{\star \star \star} \\
(2.60) \S\end{array}$ & $\begin{array}{l}1.38^{\star \star \star} \\
(2.84) \S\end{array}$ & $\begin{array}{l}-0.44^{\star \star} \\
(-2.29)\end{array}$ & $\begin{array}{l}-1.50^{\star \star} \\
(-4.14) \S\end{array}$ & $\begin{array}{l}-0.56 \\
(-0.76)\end{array}$ & $\begin{array}{c}-0.04 \\
(-0.14)\end{array}$ & $\begin{array}{l}0.69 \\
(0.71) \S\end{array}$ & $\begin{array}{l}-0.04 \\
(-0.08) \S\end{array}$ & $\begin{array}{l}-1.39^{\star \star \star} \\
(6.56)\end{array}$ & $\begin{array}{l}-2.69^{\star \star \star} \\
(-5.63) \S\end{array}$ & $\begin{array}{l}-1.98^{\star \star} \\
(-2.24)\end{array}$ & $\begin{array}{l}9.54^{\star \star} \\
(2.13) \S\end{array}$ & $\begin{array}{l}3.13 \\
(1.03)\end{array}$ & $\begin{array}{l}-0.20 \\
(-0.16)\end{array}$ & $\begin{array}{l}0.28 \\
(0.15)\end{array}$ & $\begin{array}{l}0.19 \\
(0.08)\end{array}$ \\
\hline $\begin{array}{l}\text { \# of observation } \\
\text { \# of countries }\end{array}$ & \multicolumn{6}{|c|}{$\begin{array}{c}2523 \\
27\end{array}$} & \multicolumn{5}{|c|}{$\begin{array}{c}2523 \\
27\end{array}$} & \multicolumn{5}{|c|}{$\begin{array}{c}724 \\
27\end{array}$} \\
\hline Epl_eprv1 & $\begin{array}{l}-0.08 \\
(-1.03)\end{array}$ & $\begin{array}{l}-0.15^{\star \star \star} \\
(-2.90) \S\end{array}$ & $\begin{array}{l}-0.03^{\star} \\
(-1.81)\end{array}$ & $\begin{array}{l}-0.02 \\
(-0.44)\end{array}$ & $\begin{array}{l}-0.08 \\
(-1.38)\end{array}$ & $\begin{array}{l}-0.05^{\star} \\
(-1.92)\end{array}$ & $\begin{array}{l}0.19^{\star \star \star} \\
(2.84)\end{array}$ & $\begin{array}{l}0.13^{\star \star \star} \\
(3.57)\end{array}$ & $\begin{array}{l}0.17^{\star \star \star} \\
(7.57)\end{array}$ & $\begin{array}{l}0.16^{\star \star *} \\
(5.77)\end{array}$ & $\begin{array}{l}0.08 \\
(1.53)\end{array}$ & $\begin{array}{l}-0.65 \\
(-1.35)\end{array}$ & $\begin{array}{l}-0.50 \\
(-1.47)\end{array}$ & $\begin{array}{l}-0.27^{\star} \\
(-1.88)\end{array}$ & $\begin{array}{l}0.09 \\
(0.61) \S\end{array}$ & $\begin{array}{l}-0.08 \\
(-0.37)\end{array}$ \\
\hline $\begin{array}{l}\text { \# of observation } \\
\text { \# of countries }\end{array}$ & \multicolumn{6}{|c|}{$\begin{array}{r}2742 \\
33\end{array}$} & \multicolumn{5}{|c|}{$\begin{array}{r}2742 \\
33\end{array}$} & \multicolumn{5}{|c|}{$\begin{array}{r}743 \\
33\end{array}$} \\
\hline $\begin{array}{l}\text { \# of observation } \\
\text { \# of countries }\end{array}$ & \multicolumn{6}{|c|}{$\begin{array}{r}2978 \\
28\end{array}$} & \multicolumn{5}{|c|}{$\begin{array}{r}2978 \\
28\end{array}$} & \multicolumn{5}{|c|}{$\begin{array}{r}909 \\
28\end{array}$} \\
\hline reg_Im3_efw ${ }^{2}$ & $\begin{array}{l}0.02 \\
(0.47)\end{array}$ & $\begin{array}{l}0.02 \\
(0.61)\end{array}$ & $\begin{array}{l}0.07^{\star \star \star} \\
(5.37)\end{array}$ & $\begin{array}{l}0.07^{\star \star \star} \\
(3.86)\end{array}$ & $\begin{array}{l}0.06 \\
(1.39)\end{array}$ & $\begin{array}{l}0.05^{\star \star \star} \\
(2.83)\end{array}$ & $\begin{array}{l}0.02 \\
(0.37)\end{array}$ & $\begin{array}{l}0.04 \\
(1.05) \S\end{array}$ & $\begin{array}{l}0.10^{\star \star \star} \\
(8.64)\end{array}$ & $\begin{array}{l}0.10^{\star \star \star} \\
(4.61)\end{array}$ & $\begin{array}{l}0.11^{\star \star \star} \\
(3.17)\end{array}$ & $\begin{array}{l}0.19 \\
(0.52)\end{array}$ & $\begin{array}{l}0.14 \\
(0.52)\end{array}$ & $\begin{array}{l}0.16^{\star \star \star} \\
(2.65)\end{array}$ & $\begin{array}{l}0.29^{\star *} \\
(2.11)\end{array}$ & $\begin{array}{l}0.35^{\star \star} \\
(2.48)\end{array}$ \\
\hline $\begin{array}{l}\text { \# of observation } \\
\text { \# of countries }\end{array}$ & \multicolumn{6}{|c|}{$\begin{array}{r}2285 \\
38 \\
\end{array}$} & \multicolumn{5}{|c|}{$\begin{array}{r}2285 \\
38 \\
\end{array}$} & \multicolumn{5}{|c|}{$\begin{array}{r}608 \\
38 \\
\end{array}$} \\
\hline $\begin{array}{l}\text { Frequency } \\
\text { Fixed effects }\end{array}$ & \multicolumn{6}{|c|}{$\begin{array}{r}\text { quarterly } \\
\text { no }\end{array}$} & \multicolumn{5}{|c|}{$\begin{array}{l}\text { quarterly } \\
\text { country }\end{array}$} & \multicolumn{5}{|c|}{$\begin{array}{r}\text { annual } \\
\text { no }\end{array}$} \\
\hline
\end{tabular}

Note: Each regression includes only one labour market variable at a time and includes the following control variables which are not reported: population (log), GDP p.c. (log), trade openness, government revenues in \% of GDP; real short-term interest rate. ${ }^{*}, * *, * * *$ signify coefficients significant at the 10,5 and $1 \%$ level respectively. T-values in parenthesis are based on bootstrapped standard errors. Coefficient significantly different from zero at the 10,5 or $1 \%$ level are bolded. ${ }^{1}$ set of control variables does not include government revenues because it is highly correlated with policy variable. ${ }^{2}$ set of control variables does not include government revenues and GDP per capita because they is highly correlated with policy variable. § signifies that the coefficient is significantly different from the median coefficient at least at the $10 \%$ level. 
Table 6. Results: external policies

\begin{tabular}{|c|c|c|c|c|c|c|c|c|c|c|c|c|c|c|c|c|}
\hline & \multicolumn{6}{|c|}{ Dependent variable: GDP growth (demeaned) } & \multicolumn{5}{|c|}{ Dependent variable: GDP growth } & \multicolumn{5}{|c|}{ Dependent variable: GDP growth (demeaned) } \\
\hline & q5 & q10 & q50 & q90 & q95 & OLS & q5 & $q 10$ & $\mathrm{q} 50$ & 990 & q95 & q5 & $\mathrm{q} 10$ & $\mathrm{q} 50^{\circ}$ & 990 & q95 \\
\hline K_open & $\begin{array}{l}-0.52^{\star} \\
(-1.77) \S\end{array}$ & $\begin{array}{l}-0.39 \star \star \star \\
(-2.76) \S\end{array}$ & $\begin{array}{l}-0.00 \\
(-0.05)\end{array}$ & $\begin{array}{l}-0.17^{\star \star} \\
(-1.99) \S\end{array}$ & $\begin{array}{l}-0.04 \\
(-0.22)\end{array}$ & $\begin{array}{l}-0.17^{\star *} \\
(-2.13)\end{array}$ & $\begin{array}{l}0.06 \\
(0.23)\end{array}$ & $\begin{array}{l}0.22 \\
(1.42)\end{array}$ & $\begin{array}{l}0.39^{\star \star \star} \\
(5.02)\end{array}$ & $\begin{array}{l}0.31^{\star \star \star} \\
(3.01)\end{array}$ & $\begin{array}{l}0.28 \\
(1.56)\end{array}$ & $\begin{array}{l}-3.47^{\star \star \star} \\
(-2.96) \S\end{array}$ & $\begin{array}{l}-1.65^{\star \star} \\
(-2.04) \S\end{array}$ & $\begin{array}{l}0.11 \\
(0.30)\end{array}$ & $\begin{array}{l}-0.41 \\
(-0.67)\end{array}$ & $\begin{array}{l}-0.60 \\
(-1.05)\end{array}$ \\
\hline \# of observation & \multirow{2}{*}{\multicolumn{6}{|c|}{$\begin{array}{c}3508 \\
33\end{array}$}} & \multirow{2}{*}{\multicolumn{5}{|c|}{$\begin{array}{c}3508 \\
33\end{array}$}} & \multirow{2}{*}{\multicolumn{5}{|c|}{$\begin{array}{c}1002 \\
33\end{array}$}} \\
\hline \# of countries & & & & & & & & & & & & & & 33 & & \\
\hline Fin_open & $\begin{array}{l}-0.00 \\
(-0.85)\end{array}$ & $\begin{array}{l}-0.00 \\
(-1.13)\end{array}$ & $\begin{array}{l}-0.00 \\
(-0.92)\end{array}$ & $\begin{array}{l}0.00 \\
(0.97)\end{array}$ & $\begin{array}{l}0.00 \\
(1.48) \S\end{array}$ & $\begin{array}{c}-0.00 \\
(-0.86)\end{array}$ & $\begin{array}{l}-0.00^{\star *} \\
(-2.12)\end{array}$ & $\begin{array}{l}-0.00^{\star \star \star} \\
(-2.87)\end{array}$ & $\begin{array}{l}-0.00^{\star \star *} \\
(-5.30)\end{array}$ & $\begin{array}{l}-0.00 \\
(-1.58) \S\end{array}$ & $\begin{array}{l}-0.00 \\
(-1.02) \S\end{array}$ & $\begin{array}{l}-0.00 \\
(-0.93)\end{array}$ & $\begin{array}{l}-0.00^{\star} \\
(-1.81)\end{array}$ & $\begin{array}{l}-0.00 \\
(-0.77)\end{array}$ & $\begin{array}{l}-0.00^{\star *} \\
(-2.44)\end{array}$ & $\begin{array}{l}-0.00^{\star \star \star} \\
(-2.92) \S\end{array}$ \\
\hline $\begin{array}{l}\text { \# of observation } \\
\text { \# of countries }\end{array}$ & \multicolumn{6}{|c|}{$\begin{array}{c}1837 \\
34\end{array}$} & \multicolumn{5}{|c|}{$\begin{array}{c}1837 \\
34\end{array}$} & \multicolumn{5}{|c|}{$\begin{array}{c}467 \\
34\end{array}$} \\
\hline FX_reserves & $\begin{array}{l}0.03^{\star \star \star} \\
(4.60) \S\end{array}$ & $\begin{array}{l}0.03^{\star \star \star} \\
(7.22) \S\end{array}$ & $\begin{array}{l}0.01^{\star *} \\
(2.01)\end{array}$ & $\begin{array}{l}-0.01^{*} \\
(-1.84) \S\end{array}$ & $\begin{array}{l}-0.01^{\star *} \\
(-2.40) \S\end{array}$ & $\begin{array}{l}0.01^{*} \\
(1.88)\end{array}$ & $\begin{array}{l}0.03^{\star \star \star} \\
(4.09) \S\end{array}$ & $\begin{array}{l}0.03^{\star \star \star} \\
(6.57) \S\end{array}$ & $\begin{array}{l}0.01^{\star \star \star} \\
(3.77)\end{array}$ & $\begin{array}{l}-0.01^{\star \star} \\
(-2.11) \S\end{array}$ & $\begin{array}{l}-0.02^{\star \star \star} \\
(-3.96) \S\end{array}$ & $\begin{array}{l}0.10^{\star \star \star} \\
(2.61) \S\end{array}$ & $\begin{array}{l}0.03 \\
(1.18)\end{array}$ & $\begin{array}{l}0.01 \\
(1.18)\end{array}$ & $\begin{array}{l}0.02 \\
(0.64)\end{array}$ & $\begin{array}{l}0.07^{\star} \\
(1.95) \S\end{array}$ \\
\hline $\begin{array}{l}\text { \# of observation } \\
\text { \# of countries }\end{array}$ & \multicolumn{6}{|c|}{$\begin{array}{c}3714 \\
34\end{array}$} & \multicolumn{5}{|c|}{$\begin{array}{c}3714 \\
34\end{array}$} & \multicolumn{5}{|c|}{$\begin{array}{c}1050 \\
34\end{array}$} \\
\hline fxclass_coarse & $\begin{array}{l}0.05 \\
(0.76)\end{array}$ & $\begin{array}{l}0.04 \\
(0.99)\end{array}$ & $\begin{array}{l}0.04^{\star *} \\
(2.25)\end{array}$ & $\begin{array}{l}0.07^{\star *} \\
(1.98)\end{array}$ & $\begin{array}{l}0.09^{\star *} \\
(2.27)\end{array}$ & $\begin{array}{l}0.05^{\star \star} \\
(2.14)\end{array}$ & $\begin{array}{l}0.02 \\
(0.18)\end{array}$ & $\begin{array}{l}-0.00 \\
(-0.10)\end{array}$ & $\begin{array}{l}0.03 \\
(1.56)\end{array}$ & $\begin{array}{l}0.07^{\star \star} \\
(2.06)\end{array}$ & $\begin{array}{l}0.06 \\
(1.59)\end{array}$ & $\begin{array}{l}0.70 \\
(1.26)\end{array}$ & $\begin{array}{l}0.21 \\
(0.79)\end{array}$ & $\begin{array}{l}0.14 \\
(1.38)\end{array}$ & $\begin{array}{l}0.17 \\
(1.20)\end{array}$ & $\begin{array}{l}0.21 \\
(1.17)\end{array}$ \\
\hline $\begin{array}{l}\text { \# of observation } \\
\text { \# of countries }\end{array}$ & \multicolumn{6}{|c|}{$\begin{array}{r}3104 \\
30\end{array}$} & \multicolumn{5}{|c|}{$\begin{array}{r}3104 \\
30\end{array}$} & \multicolumn{5}{|c|}{$\begin{array}{r}884 \\
30\end{array}$} \\
\hline $\begin{array}{l}\text { Frequency } \\
\text { Fixed effects }\end{array}$ & \multicolumn{6}{|c|}{$\begin{array}{r}\begin{array}{r}\text { quarterly } \\
\text { no }\end{array} \\
\end{array}$} & \multicolumn{5}{|c|}{$\begin{array}{c}\text { quarterly } \\
\text { country }\end{array}$} & \multicolumn{5}{|c|}{$\begin{array}{r}\text { annual } \\
\text { no } \\
\end{array}$} \\
\hline
\end{tabular}

Note: Each regression includes only one external policy variable at a time and includes the following control variables which are not reported: population (log), GDP p.c. (log), trade openness, government revenues in \% of GDP; real short-term interest rate. ****** signify coefficients significant at the 10,5 and $1 \%$ level respectively. T-values in parenthesis are based on bootstrapped standard errors. Coefficient significantly different from zero at the 10,5 or $1 \%$ level are bolded. $\S$ signifies that the coefficient is significantly different from the median coefficient at least at the $10 \%$ level. 
Table 7. Policies and GDP tail risks

\begin{tabular}{|c|c|c|}
\hline & $\begin{array}{l}\text { Negative GDP tail risk } \\
\text { Bottom quantiles of the } \\
\text { conditional GDP distribution }\end{array}$ & $\begin{array}{c}\text { Positive GDP tail risk } \\
\text { Top quantiles of the } \\
\text { conditional GDP distribution }\end{array}$ \\
\hline \multicolumn{3}{|l|}{ Macroeconomic policies } \\
\hline Higher automatic stabilisers & $(+)$ & - \\
\hline \multicolumn{3}{|l|}{ Financial market characteristics } \\
\hline More liberalised financial markets & + & $(-)$ \\
\hline More developed capital markets & + & $(-)$ \\
\hline Effective prudential banking supervision & + & $(-)$ \\
\hline \multicolumn{3}{|l|}{ Greater use of macroprudential policies } \\
\hline Greater use of macroprudential policies & ns & - \\
\hline Borrower targeted instruments & ns & - \\
\hline Debt-to-income ratio & $(+)$ & - \\
\hline Taxes on financial institutions & $(+)$ & - \\
\hline Loan-to-value ratio caps & ns & - \\
\hline Limits on interbank exposures & ns & $(-)$ \\
\hline \multicolumn{3}{|l|}{ Institutional quality } \\
\hline Greater government effectiveness & + & $(-)$ \\
\hline Greater regulatory quality & + & $(-)$ \\
\hline Greater voice and accountability & + & $(-)$ \\
\hline Greater rule of law & + & $(-)$ \\
\hline Greater political stability & + & + \\
\hline Greater control of corruption & + & $(-)$ \\
\hline \multicolumn{3}{|l|}{ Labour market characteristics } \\
\hline More generous unemployment benefits & ns & - \\
\hline Greater spending in ALMPs & $(+)$ & inconclusive \\
\hline Higher degree of wage bargaining coordination & ns & $(-)$ \\
\hline Greater wage bargaining decentralisation & ns & $(+)$ \\
\hline Higher minimum wages & $(+)$ & inconclusive \\
\hline \multicolumn{3}{|l|}{ External policies } \\
\hline Greater openness to capital flows & $(-)$ & inconclusive \\
\hline Greater international reserves & $(+)$ & inconclusive \\
\hline
\end{tabular}

Note: The table synthesises the empirical results. + or - signifies robust results (when sign and significance is robust across all three specifications). (+) or (-) signifies relatively robust results (when sign and significance is robust across two out of three specifications). Inconclusive signifies when signs (and significance) change across specifications. ns: signifies non-significant effect across all specifications. Inconclusive results on both bottom and top quantiles are not included in this summary table. 


\section{REFERENCES}

Abiad, A. E. Detragiache, T. Tressel (2008), "A New Database of Financial Reforms", IMF Working Paper, No. 266.

Acemoglu, D, A. Ozdaglar and A. Tahbaz-Salehi (2015), "Microeconomic origins of macroeconomic tail risks", NBER Working Paper, No. 20865.

Acemoglu , D., S. Johnson, J. Robinson, Y. Thaicharoen (2003), "Institutional Causes, Macroeconomic Symptoms: Volatility, Crises and Growth”, Journal of Monetary Economics, 50 (2003) 49-123.

Adrian, T., N. Boyarchenko and D. Giannone (2016), "Vulnerable Growth", Federal Reserve Bank of New York Staff Reports, No. 794.

Ahrend, R., J. Arnold, C. Moeser (2011), “The Sharing of Macroeconomic Risk: Who Loses (and Gains) from Macroeconomic Shocks", OECD Economics Department Working Papers, No. 877, OECD Publishing.

Andrews, D. (2010), "Real House Prices in OECD Countries: The Role of Demand Shocks and Structural and Policy Factors", OECD Economics Department Working Papers, No. 831, OECD Publishing.

Andini, M. and C. Andini (2014), "Finance, growth and quantile parameter heterogeneity", Journal of Macroeconomics, Vol. 40, pp. 308-322.

Bassanini, A. and R. Duval (2006), "Employment Patterns in OECD Countries: Reassessing the Role of Policies and Institutions", OECD Economics Department Working Papers, No. 486, OECD Publishing.

Bhagwati J. (1998) "The capital myth: The difference between trade in widgets and dollars", Foreign Affairs, May/June 1998; 77, 3.

Blanchard, O., F. Jaumotte and P. Loungani (2013) "Labour market policies and IMF advice in advanced economies during the Great Recession", IMF Staff Discussion Note, 13/02.

Blanchard, O. (1999), European Unemployment: The Role of Shocks and Institutions, Banca d'Italia, https://www.bancaditalia.it/pubblicazioni/lezioni-baffi/pblecture-05/index.html

Catte, P. N. Girouard, R. Price, C. André (2004), "The Contribution of Housing Markets to Cyclical Resilience", OECD Economic Studies No. 38, 2004/1.

Cecchetti, S. G. and H. Li. (2008), "Measuring the impact of asset price booms using quantile vector autoregressions", Brandeis University, mimeo.

Cerutti, E., S. Claessens and L. Laeven (2015), "The Use and Effectiveness of Macroprudential Policies: New Evidence", IMF Working Paper, No. 15/61. 
Chernozhukov, V. and I. Fernández-Val (2011), "Inference for Extremal Conditional Quantile Models, with an Application to Market and Birthweight Risks", Review of Economic Studies, Vol. 78, pp. 559-589.

Claessens, S. (2014), “An Overview of Macroprudential Policy Tools”, IMF Working Paper, No. 14/214,

Claessens, S., S. Ghosh and R. Mihet (2013), "Macro-prudential policies to mitigate financial system vulnerabilities", Journal of International Money and Finance, Vol. 39, pp. 153-185,

Cournède, B., O. Denk and P. Hoeller (2015), "Finance and Inclusive Growth", OECD Economic Policy Paper, No.14. OECD Publishing.

Cottarelli, C. and A. Fedelino (2010), "Automatic Stabilizers and the Size of Government: Correcting a Common Misunderstanding," IMF Working Paper, No. 10/155.

Crowe, C., et al. (2013), "How to deal with real estate booms: Lessons from country experiences", Journal of Financial Stability, Vol. 9/3, pp. 300-319, http://dx.doi.org/10.1016/j.jfs.2013.05.003

De Nicolò, G., and M. Lucchetta, (2011), "Systemic risks and the macro-economy", NBER Working Paper, No. 16998.

De Nicoló, M. G. and M. Lucchetta, (2012), "Systemic real and financial risks: measurement, forecasting, and stress testing", IMF Working Paper, WP/12/58.

Dell'Ariccia, G., D. Igan, L. Laeven, H. Tong, B. Bakker and J. Vandenbussche (2012), "Policies for Macrofinancial Stability: How to Deal with Credit Booms," IMF Staff Discussion Note 12/06.

Duval, R. and L. Vogel (2008), "Economic Resilience to Shocks: The Role of Structural Policies", OECD Journal: Economic Studies, Vol. 2008/1.

D'Agostino, R. B., A. Belanger, and R. B. D’Agostino (1990), “A Suggestion for Using Powerful and Informative Tests of Normality”, The American Statistician, Vol. 44, No. 4 (Nov., 1990), pp. 316321.

Fagiolo, G, M Napoletano, and A Roventini (2008), "Are output growth-rate distributions fat-tailed? Some evidence from OECD countries", Journal of Applied Econometrics, 23, 639-669.

Fall, F. and J.-M. Fournier (2015), "Macroeconomic uncertainties, prudent debt targets and fiscal rules", OECD Economics Department Working Papers, No. 1230, OECD Publishing, Paris.

Fournier, J.-M. and I. Koske (2012), "Less income inequality and more growth - Are they compatible? Part 7. The drivers of labour earnings inequality - An analysis based on conditional and unconditional quantile regressions", OECD Economics Department Working Papers, No. 930, OECD Publishing, Paris.

IMF (2012), "Dealing with Household Debt" in IMF, World Economic Outlook: Growth Resuming, Dangers Remain, International Monetary Fund.

Mello, M. and R. Perelli (2003), "Growth equations: a quantile regression exploration", The Quarterly Review of Economics and Finance, Vol. 43, pp. 643-667. 
Laeven, L. (2014), “The development of local capital markets: rationale and challenges", IMF Working Paper, No. 14/234.

Lim, C., et al. (2011), "Macroprudential Policy: What Instruments and How to Use Them? Lessons from Country Experiences", IMF Working Paper, No. 11/238,

Linnemann , L.and R. Winkler (2015), "Estimating nonlinear effects of fiscal policy using quantile regression methods", University of Dortmund, mimeo.

Obstfeld, M., J. C. Shambaugh, A. M. Taylor (2010), "Financial Stability, the Trilema, and International Reserves", American Economic Journal: Macroeconomics: 57-94.

OECD (2011), Economic Outlook, Volume 2011/1, http://www.oecd.org/eco/outlook/47836248.pdf

Rodrik, D. (1998), "Where did All the Growth Go? External Shocks, Social Conflict, and Growth Collapses", NBER Working Papers, 6350. http://www.nber.org/papers/w6350.pdf

Royston, P. (1983), "A simple method for evaluating the Shapiro-Francia W' test for non-normality", The Statistician, Vol. 32, pp. 297-300.

Royston, P. (1991), “Comment on sg3.4 and an improved D'Agostino test”, Stata Technical Bulletin, Vol. 3, pp. 23-24.

Royston, P. (1993), “A pocket-calculator algorithm for the Shapiro-Francia test for non-normality: An application to medicine", Statistics in Medicine, Vol.12, pp. 181-184.

Shapiro, S. S., and R. S. Francia (1972), "An approximate analysis of variance test for normality”, Journal of the American Statistical Association, Vol. 67, pp. 215-216.

Shapiro, S. and M. B.Wilk, (1965). "An analysis of variance test for normality (complete samples)", Biometrika,Vol. 52, pp. 591-611

Sutherland, D. and P. Hoeller (2013), "Growth-promoting Policies and Macroeconomic Stability", OECD Economics Department Working Papers, No. 1091, OECD Publishing

Stiglitz, J. E. (2015), “Towards a general theory of deep downturns”, NBER Working Paper No. 21444.

Ziemann, V. (2013), "Do Structural Policies Affect Macroeconomic Stability?", OECD Economics Department Working Papers, No. 1075, OECD Publishing, http://dx.doi.org/10.1787/5k43krfllgxten 
Appendix 1: Normality test results

Table A1.1. Summary statistics and normality tests (GDP q-on-q growth)

\begin{tabular}{|c|c|c|c|c|c|c|c|c|c|c|c|}
\hline Country & Observations & Mean & Std. deviation & Skewness & Kurtosis & P_Dagostino & $\begin{array}{c}\text { P_Dagostino } \\
\text { adj }\end{array}$ & P_skew & P_kurt & $\begin{array}{c}\text { P_Shapiro_W } \\
\text { ilk }\end{array}$ & $\begin{array}{c}\text { P_Shapiro_Fr } \\
\text { ancia }\end{array}$ \\
\hline USA & 221 & 0.75 & 0.84 & -0.25 & 4.52 & 0.00 & 0.00 & 0.12 & 0.00 & 0.00 & 0.00 \\
\hline JPN & 221 & 0.96 & 1.34 & -0.07 & 4.46 & 0.01 & 0.01 & 0.65 & 0.00 & 0.00 & 0.00 \\
\hline DEU & 221 & 0.60 & 0.98 & -0.59 & 6.37 & 0.00 & 0.00 & 0.00 & 0.00 & 0.00 & 0.00 \\
\hline FRA & 221 & 0.71 & 0.94 & 1.03 & 22.93 & 0.00 & 0.00 & 0.00 & 0.00 & 0.00 & 0.00 \\
\hline ITA & 221 & 0.60 & 1.01 & 0.23 & 4.70 & 0.00 & 0.00 & 0.16 & 0.00 & 0.00 & 0.00 \\
\hline GBR & 221 & 0.60 & 0.97 & 0.47 & 7.26 & 0.00 & 0.00 & 0.00 & 0.00 & 0.00 & 0.00 \\
\hline CAN & 217 & 0.80 & 0.86 & 0.08 & 3.92 & 0.06 & 0.06 & 0.64 & 0.02 & 0.01 & 0.01 \\
\hline AUS & 221 & 0.86 & $\begin{array}{l}1.06 \\
\end{array}$ & 0.39 & 3.79 & 0.01 & 0.01 & 0.02 & 0.04 & 0.00 & 0.00 \\
\hline AUT & 78 & 0.44 & 0.75 & -0.63 & 4.15 & 0.01 & 0.02 & 0.02 & 0.05 & 0.03 & 0.02 \\
\hline BEL & 82 & 0.44 & 0.57 & -1.35 & 7.93 & 0.00 & 0.00 & 0.00 & 0.00 & 0.00 & 0.00 \\
\hline $\mathrm{CHL}$ & 82 & 1.10 & 1.05 & 0.08 & 3.92 & 0.22 & 0.20 & 0.75 & 0.08 & 0.26 & 0.11 \\
\hline CZE & 101 & 0.36 & 2.11 & -1.65 & 13.11 & 0.00 & 0.00 & 0.00 & 0.00 & 0.00 & 0.00 \\
\hline DNK & 98 & 0.37 & 0.91 & -0.17 & 3.82 & 0.19 & 0.18 & 0.48 & 0.09 & 0.33 & 0.17 \\
\hline EST & 81 & 1.02 & 2.05 & -2.29 & 12.82 & 0.00 & 0.00 & 0.00 & 0.00 & 0.00 & 0.00 \\
\hline FIN & $\begin{array}{l}01 \\
182\end{array}$ & 0.60 & $\begin{array}{l}.05 \\
1.45\end{array}$ & $\begin{array}{l}-2.29 \\
-0.52\end{array}$ & 8.80 & 0.00 & 0.00 & 0.00 & 0.00 & 0.00 & 0.00 \\
\hline GRC & 82 & 0.24 & 1.45 & -0.73 & 3.97 & 0.01 & 0.01 & 0.01 & 0.08 & 0.02 & 0.02 \\
\hline HUN & 82 & 0.53 & 0.91 & -2.83 & 13.56 & 0.00 & 0.00 & 0.00 & 0.00 & 0.00 & 0.00 \\
\hline ISL & 74 & 0.82 & 3.02 & 0.09 & 3.39 & 0.56 & 0.55 & 0.73 & 0.31 & 0.93 & 0.67 \\
\hline IRL & 74 & $\begin{array}{l}0.02 \\
1.11\end{array}$ & $\begin{array}{l}.02 \\
2.07\end{array}$ & 0.31 & $\begin{array}{l}.09 \\
3.15\end{array}$ & $\begin{array}{l}0.00 \\
0.42\end{array}$ & 0.40 & $\begin{array}{l}0.13 \\
0.25\end{array}$ & 0.53 & $\begin{array}{l}0.90 \\
0.36\end{array}$ & $\begin{array}{l}0.01 \\
0.31\end{array}$ \\
\hline ISR & 82 & 0.95 & 0.98 & 0.10 & 3.60 & 0.38 & 0.37 & 0.70 & 0.18 & 0.41 & 0.26 \\
\hline KOR & 181 & 1.75 & 1.77 & -0.33 & 6.67 & 0.00 & 0.00 & 0.07 & 0.00 & 0.00 & 0.00 \\
\hline LUX & 82 & 0.87 & 2.03 & -0.18 & 4.59 & 0.05 & 0.05 & 0.49 & 0.02 & 0.07 & 0.02 \\
\hline MEX & $\begin{array}{l}02 \\
142\end{array}$ & 0.63 & $\begin{array}{l}2.05 \\
1.31\end{array}$ & $\begin{array}{l}-1.1 \\
-1.45\end{array}$ & $\begin{array}{l}4.59 \\
7.02\end{array}$ & 0.00 & 0.00 & 0.00 & 0.00 & 0.00 & 0.00 \\
\hline NLD & 221 & 0.70 & 1.42 & 0.39 & 11.42 & 0.00 & 0.00 & 0.02 & 0.00 & 0.00 & 0.00 \\
\hline NZL & 221 & 0.69 & 3.13 & -0.50 & 13.43 & 0.00 & 0.00 & 0.00 & 0.00 & 0.00 & 0.00 \\
\hline NOR & 150 & 0.64 & 1.09 & 0.77 & 5.19 & 0.00 & 0.00 & 0.00 & 0.00 & 0.00 & 0.00 \\
\hline $\mathrm{POL}$ & 82 & $\begin{array}{l}0.04 \\
1.01\end{array}$ & $\begin{array}{l}1.09 \\
1.03\end{array}$ & 0.50 & $\begin{array}{l}0.19 \\
12.14\end{array}$ & 0.00 & 0.00 & 0.06 & 0.00 & 0.00 & 0.00 \\
\hline PRT & 82 & 0.32 & 0.85 & -0.60 & 3.31 & 0.05 & 0.06 & 0.03 & 0.36 & 0.08 & 0.06 \\
\hline SVK & 89 & 1.02 & 1.71 & -1.76 & 18.59 & 0.00 & 0.00 & 0.00 & 0.00 & 0.00 & 0.00 \\
\hline SVN & 82 & 0.64 & 1.15 & -1.71 & 9.03 & 0.00 & 0.00 & 0.00 & 0.00 & 0.00 & 0.00 \\
\hline ESP & $\begin{array}{l}02 \\
182\end{array}$ & $\begin{array}{l}0.64 \\
0.63\end{array}$ & 0.80 & 0.00 & $\begin{array}{l}.00 \\
4.23\end{array}$ & 0.03 & 0.04 & $\begin{array}{l}.00 \\
1.00\end{array}$ & 0.01 & 0.01 & 0.01 \\
\hline SWE & 90 & 0.61 & 0.96 & -1.52 & 7.88 & 0.00 & 0.00 & 0.00 & 0.00 & 0.00 & 0.00 \\
\hline $\mathrm{CHE}$ & 142 & 0.44 & 0.67 & -0.65 & 4.42 & 0.00 & 0.00 & 0.00 & 0.01 & 0.00 & 0.00 \\
\hline TUR & 70 & 0.92 & 2.18 & -0.97 & 5.04 & 0.00 & 0.00 & 0.00 & 0.01 & 0.00 & 0.00 \\
\hline BRA & 78 & 0.67 & $\begin{array}{l}2.10 \\
1.22\end{array}$ & -0.84 & $\begin{array}{l}.04 \\
4.91\end{array}$ & 0.00 & 0.00 & 0.00 & 0.01 & 0.00 & 0.00 \\
\hline $\mathrm{CHN}$ & 94 & 2.39 & 0.60 & 0.55 & 2.54 & 0.06 & 0.06 & 0.03 & 0.37 & 0.00 & 0.00 \\
\hline $\mathrm{COL}$ & $\begin{array}{l}54 \\
62\end{array}$ & $\begin{array}{l}2.09 \\
1.05\end{array}$ & $\begin{array}{l}0.00 \\
0.90\end{array}$ & $\begin{array}{l}0.00 \\
0.30\end{array}$ & $\begin{array}{l}.54 \\
3.16\end{array}$ & $\begin{array}{l}0.46 \\
0.46\end{array}$ & 0.45 & $\begin{array}{l}0.03 \\
0.30\end{array}$ & 0.51 & 0.53 & 0.44 \\
\hline IND & 78 & 1.89 & 3.00 & 6.31 & 52.14 & 0.00 & 0.00 & 0.00 & 0.00 & 0.00 & 0.00 \\
\hline IDN & $\begin{array}{l}10 \\
62\end{array}$ & $\begin{array}{l}1.09 \\
1.33\end{array}$ & $\begin{array}{l}0.61 \\
0.61\end{array}$ & $\begin{array}{l}0.31 \\
-0.32\end{array}$ & 6.92 & 0.00 & 0.00 & 0.27 & 0.00 & 0.00 & 0.00 \\
\hline LVA & 81 & 1.00 & 2.14 & -0.74 & 4.41 & 0.00 & 0.01 & 0.01 & 0.03 & 0.01 & 0.01 \\
\hline RUS & 50 & 0.82 & 1.48 & -1.36 & 4.92 & 0.00 & 0.00 & 0.00 & 0.02 & 0.00 & 0.00 \\
\hline $\mathrm{ZAF}$ & 221 & 0.77 & $\begin{array}{l}1.06 \\
\text { S }\end{array}$ & 0.24 & 4.56 & 0.00 & 0.00 & 0.14 & 0.00 & 0.00 & 0.00 \\
\hline
\end{tabular}

Note: P_Dagostino refers to the p-value of the D'Agostino, Belanger, and D'Agostino (1990) test. P_Dagostino_adj denotes p-value of the D'Agostino, Belanger, and D'Agostino (1990) test with an empirical adjustment made by Royston (1991). The advantage of D'Agostino, Belanger, and D'Agostino (1990) tests is that it can be separately tested whether the normality assumption fails due to skewness or kurtosis or both. The $p$-values of these tests are reported in the columns p_skew (H0: skewness equal to 0) and p_kurtosis (H0: kurtosis $=3$ ). In addition, the Shapiro and Wilk (1965) test with a new approximation accurate for $4 \leq n \leq 2000$ and the Shapiro-Francia test (Shapiro and Francia 1972; Royston 1983; Royston 1993) are used. Figures in bold indicate that normality is rejected at least at the $10 \%$ significance level. 
ECO/WKP(2016)63

Appendix 2: Data description

Table A2.1 Dataset - Financial market characteristics indicators

\begin{tabular}{|c|c|c|c|}
\hline Variable & Abbreviation & Description & Source \\
\hline Financial reform index & Finreform & Sum of the seven components. Ranges from 0 (fully repressed) to 21 (fully liberalised) & Abiad et al. (2008) \\
\hline $\begin{array}{l}\text { Prudential supervision in the banking } \\
\text { sector }\end{array}$ & Superv & $\begin{array}{l}\text { Indicator measures the adoption of risk-based capital adequacy ratios on the basis of } \\
\text { Basle I capital accord, the independence and power of the banking supervision agency, } \\
\text { and the coverage of institutions subject to its supervision. The variable ranges from } 0-3 \\
\text { with higher scores associated with stricter banking supervision }\end{array}$ & ibid. \\
\hline Development in the security markets & Security & $\begin{array}{l}\text { Includes the assessment of policies for the development of debt and security markets and } \\
\text { their openness to international investors. Higher scores identify developed securities } \\
\text { markets accessible to foreign market agents. Ranges from } 0 \text { (least developed)- } 3 \text { (most } \\
\text { developed) }\end{array}$ & ibid. \\
\hline Interest rate controls & Icontr & $\begin{array}{l}\text { measures the presence of policy controls involving deposit or lending rates by fiat or } \\
\text { ceiling/floors of binding nature Ranges from } 0 \text { (repressed)- } 3 \text { (liberalised) }\end{array}$ & ibid. \\
\hline Financial markets entry barriers & Entry & $\begin{array}{l}\text { Measures to what extent the government allows foreign banks to enter into a domestic } \\
\text { market, whether the government allows the entry of new domestic banks, if there are there } \\
\text { restrictions on branching, and Does the government allow banks to engage in a wide range } \\
\text { of activities? Ranges from } 0 \text { (repressed)- } 3 \text { (liberalised) }\end{array}$ & ibid. \\
\hline Privatisation of the banking sector & Privat & $\begin{array}{l}\text { Share of banking sector assets controlled by state-owned banks. Ranges from } 0 \\
\text { (repressed)- } 3 \text { (fully privatised). }\end{array}$ & ibid. \\
\hline $\begin{array}{l}\text { Credit Controls and Reserve } \\
\text { Requirements }\end{array}$ & Ccontr & $\begin{array}{l}\text { Measures whether reserve requirements are restrictive, whether there are minimum } \\
\text { amounts of credit that must be channelled to certain sectors, or whether there are any } \\
\text { credits supplied to certain sectors at subsidized rates. Ranges from } 0 \text { (repressed) - } 3 \text { (fully } \\
\text { privatised). }\end{array}$ & ibid. \\
\hline
\end{tabular}




\section{ECO/WKP(2016)63}

\section{Table A2.2 Dataset - Macroprudential indicators}

\begin{tabular}{|c|c|c|c|}
\hline Variable & Abbreviation & Description & Source \\
\hline Loan-to-Value Ratio & LTV & $\begin{array}{l}\text { Constrains highly levered mortgage down-payments by enforcing or encouraging a limit or } \\
\text { by determining regulatory risk weights. }\end{array}$ & $\begin{array}{l}\text { Cerutti et al. } \\
\text { (2015) }\end{array}$ \\
\hline Loan-to-Value Ratio Caps & LTV_CAP & $\begin{array}{l}\text { Restricts to LTV used as a strictly enforced cap on new loans, as opposed to a supervisory } \\
\text { guideline or merely a determinant of risk weights. }\end{array}$ & ibid. \\
\hline Debt-to-Income Ratio & DTI & Constrains household indebtedness by enforcing or encouraging a limit. & ibid. \\
\hline $\begin{array}{l}\text { Time-Varying/Dynamic } \\
\text { Provisioning }\end{array}$ & DP & Requires banks to hold more loan-loss provisions during upturns. & ibid. \\
\hline $\begin{array}{l}\text { General Countercyclical } \\
\text { Buffer/Requirement }\end{array}$ & CTC & Requires banks to hold more capital during upturns. & ibid. \\
\hline Leverage Ratio & LEV & Limits banks from exceeding a fixed minimum leverage ratio. & ibid. \\
\hline Capital Surcharges on SIFls & SIFI & $\begin{array}{l}\text { Requires Systemically Important Financial Institutions to hold a higher capital level than } \\
\text { other financial institutions. }\end{array}$ & ibid. \\
\hline Limits on Interbank Exposures & INTER & Limits the fraction of liabilities held by the banking sector or by individual banks. & ibid. \\
\hline Concentration Limits & CONC & Limits the fraction of assets held by a limited number of borrowers. & ibid. \\
\hline Limits on Foreign Currency Loans & $\mathrm{FC}$ & Reduces vulnerability to foreign-currency risks. & ibid. \\
\hline Reserve Requirement Ratios & $\mathrm{RR}$ & Limits credit growth; can also be targeted to limit foreign-currency credit growth. & ibid. \\
\hline Levy/Tax on Financial Institutions & TAX & Taxes on financial institutions. & ibid. \\
\hline Macroprudential Index $(0-12)$ & MPI & LTV_CAP + DTI + DP + CTC + LEV + SIFI + INTER + CONC + FC + TAX & ibid. \\
\hline Borrower-Targeted Instruments (0-2) & BORROWER & LTV_CAP + DTI & ibid. \\
\hline $\begin{array}{l}\text { Financial Institution-Targeted Instruments } \\
(0-10)\end{array}$ & FINANCIAL & $\mathrm{DP}+\mathrm{CTC}+\mathrm{LEV}+\mathrm{SIFI}+\mathrm{INTER}+\mathrm{CONC}+\mathrm{FC}+\mathrm{TAX}$ & ibid. \\
\hline
\end{tabular}




\begin{tabular}{|c|c|c|c|c|}
\hline Variable & Abbreviation & Description & Source & \\
\hline Government effectiveness & Govefft & $\begin{array}{l}\text { Captures perceptions of the quality of public services, the quality of the civil service and } \\
\text { the degree of its independence from political pressures, the quality of policy formulation } \\
\text { and implementation, and the credibility of the government's commitment to such policies. } \\
\text { The indicators are in units of a standard normal distribution, with mean zero, standard } \\
\text { deviation of one, and running from approximately }-2.5 \text { to } 2.5 \text {, with higher values } \\
\text { corresponding to better governance. }\end{array}$ & $\begin{array}{l}\text { World } \\
\text { Worldwide } \\
\text { Governance } \\
\text { indicators }\end{array}$ & Bank \\
\hline Regulatory quality & Regqual & $\begin{array}{l}\text { Captures perceptions of the ability of the government to formulate and implement sound } \\
\text { policies and regulations that permit and promote private sector development. The } \\
\text { indicators are in units of a standard normal distribution, with mean zero, standard deviation } \\
\text { of one, and running from approximately }-2.5 \text { to } 2.5 \text {, with higher values corresponding to } \\
\text { better governance. }\end{array}$ & ibid. & \\
\hline Voice and accountability & Voiceacc & $\begin{array}{l}\text { Captures perceptions of the extent to which a country's citizens are able to participate in } \\
\text { selecting their government, as well as freedom of expression, freedom of association, and } \\
\text { a free media. The indicators are in units of a standard normal distribution, with mean zero, } \\
\text { standard deviation of one, and running from approximately }-2.5 \text { to } 2.5 \text {, with higher values } \\
\text { corresponding to better governance. }\end{array}$ & ibid. & \\
\hline Rule of law & Rulelaw & $\begin{array}{l}\text { Captures perceptions of the extent to which agents have confidence in and abide by the } \\
\text { rules of society, and in particular the quality of contract enforcement, property rights, the } \\
\text { police, and the courts, as well as the likelihood of crime and violence. The indicators are in } \\
\text { units of a standard normal distribution, with mean zero, standard deviation of one, and } \\
\text { running from approximately }-2.5 \text { to } 2.5 \text {, with higher values corresponding to better } \\
\text { governance. }\end{array}$ & ibid. & \\
\hline Control of corruption & Corrpt & $\begin{array}{l}\text { Captures perceptions of the extent to which public power is exercised for private gain, } \\
\text { including both petty and grand forms of corruption, as well as "capture" of the state by } \\
\text { elites and private interests. The indicators are in units of a standard normal distribution, } \\
\text { with mean zero, standard deviation of one, and running from approximately }-2.5 \text { to } 2.5 \text {, } \\
\text { with higher values corresponding to better governance. }\end{array}$ & ibid. & \\
\hline Political stability and absence of violence & Polstab & $\begin{array}{l}\text { Measures perceptions of the likelihood of political instability and/or politically-motivated } \\
\text { violence, including terrorism. The indicators are in units of a standard normal distribution, } \\
\text { with mean zero, standard deviation of one, and running from approximately }-2.5 \text { to } 2.5 \text {, } \\
\text { with higher values corresponding to better governance. }\end{array}$ & ibid. & \\
\hline
\end{tabular}


ECO/WKP(2016)63

\section{Table A2.4 Dataset - Labour market policies indicators}

\begin{tabular}{|c|c|c|c|}
\hline Variable & Abbreviation & Description & Source \\
\hline Unemployment benefits & ubgr_I & $\begin{array}{l}\text { Average gross unemployment benefit replacement rates (interpolated and } \\
\text { spliced) }\end{array}$ & OECD \\
\hline Active labour market policy & $\begin{array}{l}\text { almp_EXPPC } \\
\text { T100 }\end{array}$ & Spending in active labour market policies as a percentage of GDP & OECD \\
\hline Minimum wage & $\min 2 \mathrm{med}$ & Hourly minimum wages (\% of median wage) & OECD \\
\hline Labour regulations & Epl eprv & Regulation of regular employment contracts & OECD \\
\hline Wage bargaining coordination & coord & $\begin{array}{l}\text { Degree of wage bargaining coordination (1-5, } 5 \text { max). For details see: } \\
\text { http://www.uva-aias.net/uploaded_files/regular/ICTWSScodebook50-2.pdf }\end{array}$ & $\begin{array}{l}\text { OECD } \\
\text { ICTWSS }\end{array}$ \\
\hline Centralized collective bargaining: & reg_Im3_efw & $\begin{array}{l}\text { Variable measuring centralized collective bargaining: Wages in your country are } \\
\text { set by a centralized bargaining process }(=1) \text { or up to each individual company (= } \\
7) \text {. }\end{array}$ & Fraser Institute \\
\hline
\end{tabular}

\section{Table A2.5 Dataset - External policies indicators}

\begin{tabular}{|c|c|c|c|}
\hline Variable & Abbreviation & Description & Source \\
\hline Capital account openness (de jure) & K_open & $\begin{array}{l}\text { The level of a country international financial openness is measured using the } \\
\text { (log of) the index proposed by Chinn and Ito (2006), which is an index measuring } \\
\text { a country's degree of de jure capital account openness. }\end{array}$ & $\begin{array}{l}\text { Chinn and Ito } \\
(2006) \text { updated } \\
\text { to } 2013\end{array}$ \\
\hline Financial openeness (de facto) & Fin_open & $\begin{array}{l}\text { Sum of total external assets and liabilities in per cent of GDP. Measures de facto } \\
\text { capital account openness. }\end{array}$ & $\begin{array}{l}\text { IMF } \\
\text { International } \\
\text { Financial } \\
\text { Statistics }\end{array}$ \\
\hline Foreign reserves & FX_reserves & Non-gold reserves as a $\%$ of GDP & ibid. \\
\hline Exchange rate flexibility & fxclass_coarse & $\begin{array}{l}\text { The degree of exchange rate flexibility is measured based on the coarse } \\
\text { exchange rate regime classification of Ilzetzki, Reinhart and Rogoff }(2004) \text {. It } \\
\text { ranges from 1-6 with higher values indicating more flexible exchange rates. }\end{array}$ & $\begin{array}{l}\text { Ilzetzki, } \\
\text { and Reinhart } \\
\text { (2004). Rogoff }\end{array}$ \\
\hline
\end{tabular}


Table A2.6 Dataset - Summary statistics

\begin{tabular}{|c|c|c|c|c|c|c|c|}
\hline Variable & $\begin{array}{c}\text { Number } \\
\text { of } \\
\text { countries }\end{array}$ & $\begin{array}{l}\text { Maximum } \\
\text { time period }\end{array}$ & Mean & Min & Max & $\begin{array}{l}\text { Standard } \\
\text { deviation }\end{array}$ & $\begin{array}{l}\text { Between s.d. } \\
\text { over within } \\
\text { s.d. }\end{array}$ \\
\hline \multicolumn{8}{|l|}{ Dependent variable } \\
\hline $\begin{array}{l}\text { quarterly GDP growth in \%, } \\
\text { demeaned }\end{array}$ & 34 & $1970-2014$ & -0.13 & -13.63 & 8.46 & 1.24 & 0.14 \\
\hline \multicolumn{8}{|l|}{ Macroprudential indicators } \\
\hline Loan-to-Value Ratio & 31 & $2000-2013$ & 0.25 & 0 & 1 & 0.43 & 1.1 \\
\hline Loan-to-Value Ratio Caps & 31 & $2000-2013$ & 0.17 & 0 & 1 & 0.38 & 1.3 \\
\hline Debt-to-Income Ratio & 31 & $2000-2013$ & 0.08 & 0 & 1 & 0.26 & 0.7 \\
\hline $\begin{array}{l}\text { Time-Varying/Dynamic Loan-Loss } \\
\text { Provisioning }\end{array}$ & 31 & $2000-2013$ & 0.03 & 0 & 1 & 0.18 & n.a. ${ }^{2}$ \\
\hline $\begin{array}{l}\text { General Countercyclical Capital } \\
\text { Buffer/Requirement }\end{array}$ & 31 & $2000-2013$ & 0.00 & 0 & 1 & 0.07 & 0.3 \\
\hline Leverage Ratio & 31 & $2000-2013$ & 0.08 & 0 & 1 & 0.27 & 2.9 \\
\hline Capital Surcharges on SIFIs & 31 & $2000-2013$ & 0.01 & 0 & 1 & 0.08 & 0.4 \\
\hline Limits on Interbank Exposures & 31 & $2000-2013$ & 0.24 & 0 & 1 & 0.43 & 2.4 \\
\hline Concentration Limits & 31 & $2000-2013$ & 0.44 & 0 & 1 & 0.5 & 4.8 \\
\hline Limits on Foreign Currency Loans & 31 & $2000-2013$ & 0.06 & 0 & 1 & 0.24 & 1.3 \\
\hline Reserve Requirement Ratios & 31 & $2000-2013$ & 0.03 & 0 & 1 & 0.18 & n.a. ${ }^{2}$ \\
\hline Levy/Tax on Financial Institutions & 31 & $2000-2013$ & 0.09 & 0 & 1 & 0.29 & 0.9 \\
\hline Macroprudential Index (0-12) & 31 & $2000-2013$ & 1.20 & 0 & 5 & 1.24 & 1.4 \\
\hline $\begin{array}{l}\text { Borrower-Targeted Instruments (0- } \\
\text { 2) }\end{array}$ & 31 & $2000-2013$ & 0.24 & 0 & 2 & 0.56 & 1.0 \\
\hline $\begin{array}{l}\text { Financial Institution-Targeted } \\
\text { Instruments }(0-10)\end{array}$ & 31 & $2000-2013$ & 0.96 & 0 & 5 & 1.03 & 1.9 \\
\hline \multicolumn{8}{|l|}{ Financial market indicators } \\
\hline Financial reform index & 30 & 1973-2005 & 16.47 & 2 & 21 & 4.56 & 0.7 \\
\hline $\begin{array}{l}\text { Prudential supervision in the } \\
\text { banking sector }\end{array}$ & 30 & $1973-2005$ & 1.68 & 0 & 3 & 1.10 & 0.7 \\
\hline $\begin{array}{l}\text { Development in the security } \\
\text { markets }\end{array}$ & 30 & $1973-2005$ & 2.70 & 1 & 3 & 0.60 & 0.6 \\
\hline Interest rate controls & 30 & 1973-2005 & 2.70 & 0 & 3 & 0.78 & 0.5 \\
\hline Financial markets entry barriers & 30 & $1973-2005$ & 2.43 & 0 & 3 & 0.91 & 0.8 \\
\hline Privatisation of the banking sector & 30 & 1973-2005 & 1.97 & 0 & 3 & 1.08 & 1.5 \\
\hline $\begin{array}{l}\text { Credit Controls and Reserve } \\
\text { Requirements }\end{array}$ & 30 & $1973-2005$ & 2.36 & 0 & 3 & 0.88 & 0.9 \\
\hline \multicolumn{8}{|l|}{ Institutional quality } \\
\hline Government effectiveness & 34 & 1996-2013 & 1.38 & 0.08 & 2.36 & 0.55 & 3.5 \\
\hline Regulatory quality & 34 & $1996-2013$ & 1.3 & 0.23 & 2.08 & 0.4 & 2.7 \\
\hline Voice and accountability & 34 & 1996-2013 & 1.21 & 0.08 & 1.83 & 0.35 & 4.1 \\
\hline Rule of law & 34 & $1996-2013$ & 1.29 & -0.72 & 2.00 & 0.57 & 5.4 \\
\hline Control of corruption: & 34 & $1996-2013$ & 1.32 & -0.82 & 2.59 & 0.81 & 4.7 \\
\hline $\begin{array}{l}\text { Political stability and absence of } \\
\text { violence }\end{array}$ & 34 & $1996-2013$ & 0.8 & -1.62 & 1.67 & 0.59 & 2.9 \\
\hline \multicolumn{8}{|l|}{ Labour market } \\
\hline Unemployment benefits & 29 & $1971-2011$ & 26.39 & 0.35 & 65.2 & 13.55 & 2.1 \\
\hline Active labour market policy & 32 & $1985-2012$ & 1.79 & 0.01 & 7.19 & 1.28 & 1.8 \\
\hline Minimum wage & 27 & $1970-2013$ & 0.47 & 0.22 & 0.75 & 0.1 & 2.0 \\
\hline Labour regulations & 33 & $1985-2013$ & 2.13 & 0.26 & 4.58 & 0.82 & 4.0 \\
\hline Wage bargaining coordination & 28 & $1970-2011$ & 2.72 & 1 & 5 & 1.31 & 1.6 \\
\hline Centralized collective bargaining: & 38 & $1970-2012$ & 6.01 & 1.83 & 8.85 & 1.68 & 2.6 \\
\hline \multicolumn{8}{|l|}{ External policies } \\
\hline Capital account openness (de jure) & 33 & $1970-2013$ & 0.83 & 0 & 1 & 0.26 & 0.9 \\
\hline Financial openness (de facto) & 34 & $1975-2014$ & 912.94 & 36.81 & 29073.62 & 3411.82 & 6.4 \\
\hline Foreign reserves & 34 & $1970-2013$ & 8.05 & 0.14 & 71.84 & 7.89 & 1.2 \\
\hline Exchange rate flexibility & 30 & $1970-2010$ & 2.26 & 1 & 6 & 1.04 & 1.3 \\
\hline
\end{tabular}

1. The between dimension refers to the cross-country standard deviation of a given variable and the within dimension refers to the average standard deviation over time. 2 . The ratio cannot be computed because the within variation is zero. 
Table A2.7. Tail observations

Bottom $5 \%$ of the unconditional quarterly GDP growth distribution (demeaned)

\begin{tabular}{|c|c|c|c|c|c|c|c|c|}
\hline AUS & $1974 q 2$ & -2.8 & IRL & $1997 q 3$ & -2.1 & LUX & $1996 q 1$ & -4.8 \\
\hline AUS & $1975 q 4$ & -2.5 & IRL & $1998 q 4$ & -3.5 & LUX & $1999 q 4$ & -2.7 \\
\hline AUS & $1979 q 2$ & -2.3 & IRL & $2004 q 1$ & -3.2 & LUX & $2000 q 4$ & -4.2 \\
\hline AUS & $1982 q 4$ & -2.3 & $\mathrm{IRL}$ & $2007 q 2$ & -2.5 & LUX & $2001 q 2$ & -4.6 \\
\hline AUS & $1991 q 1$ & -2.2 & IRL & $2007 q 3$ & -2.9 & LUX & $2002 q 3$ & -2.4 \\
\hline AUT & $2008 q 4$ & -2.6 & IRL & $2008 q 1$ & -3.2 & LUX & $2002 q 4$ & -2.1 \\
\hline AUT & $2009 q 1$ & -2.3 & IRL & $2008 q 2$ & -2.5 & LUX & $2004 q 1$ & -2.3 \\
\hline AUT & $2010 q 1$ & -2.1 & $\mathrm{IRL}$ & $2008 q 4$ & -5.2 & LUX & $2008 q^{3}$ & -2.1 \\
\hline $\mathrm{BEL}$ & $2008 q 4$ & -2.8 & IRL & $2009 q 2$ & -2.4 & LUX & $2008 q 4$ & -6.6 \\
\hline BEL & $2009 q 1$ & -2.2 & IRL & $2009 q^{3}$ & -2.9 & LUX & $2009 q^{2}$ & -2.2 \\
\hline CAN & $1991 q 1$ & -2.2 & IRL & $2012 q 1$ & -2.3 & LUX & $2012 q 1$ & -3.3 \\
\hline CAN & $2009 q 1$ & -3.0 & IRL & $2012 q 3$ & -2.4 & LVA & $1998 q 4$ & -2.3 \\
\hline $\mathrm{CHE}$ & $1982 q 2$ & -2.3 & $\mathrm{IRL}$ & $2013 q 4$ & -2.5 & LVA & $1999 q 2$ & -2.7 \\
\hline $\mathrm{CHE}$ & $2008 q 4$ & -2.3 & ISL & $1998 q 1$ & -3.6 & LVA & $2001 q^{3}$ & -2.2 \\
\hline CZE & 1993q1 & -3.1 & ISL & $1999 q 2$ & -3.5 & LVA & $2008 q 2$ & -3.1 \\
\hline CZE & $1993 q 4$ & -3.0 & ISL & $2001 q 3$ & -2.5 & LVA & $2008 q 3$ & -4.9 \\
\hline CZE & $2009 q 1$ & -4.1 & ISL & $2002 q 1$ & -6.8 & LVA & $2008 q 4$ & -3.7 \\
\hline DEU & $2008 q 4$ & -2.6 & ISL & $2003 q 2$ & -3.8 & LVA & $2009 q 1$ & -4.5 \\
\hline DEU & $2009 q 1$ & -5.1 & ISL & $2005 q 1$ & -4.2 & LVA & $2009 q^{2}$ & -7.3 \\
\hline DNK & $1993 q 1$ & -2.3 & ISL & $2008 q 1$ & -3.5 & LVA & $2009 q 3$ & -6.2 \\
\hline DNK & $2008 q 4$ & -2.9 & ISL & $2008 q 3$ & -3.9 & MEX & $2008 q 4$ & -2.9 \\
\hline DNK & $2009 q 1$ & -2.1 & ISL & $2009 q 1$ & -8.2 & MEX & $2009 q^{1}$ & -4.9 \\
\hline DNK & $2009 q 2$ & -2.4 & ISL & $2009 q 4$ & -2.9 & MEX & $2013 q 2$ & -2.1 \\
\hline ESP & $1991 q 1$ & -2.8 & ISL & $2010 q 1$ & -5.5 & NLD & $1970 q 1$ & -2.1 \\
\hline ESP & 1992q2 & -2.2 & ISL & $2011 q 1$ & -3.5 & NLD & $1974 q 4$ & -2.1 \\
\hline ESP & $2009 q 1$ & -2.4 & ISL & $2011 q 4$ & -2.7 & NLD & $1975 q 1$ & -2.7 \\
\hline EST & $1998 q 4$ & -3.1 & ISL & $2012 q 4$ & -2.5 & NLD & $1976 q 4$ & -2.4 \\
\hline EST & $2004 q 2$ & -3.3 & ISL & $2014 q 1$ & -4.8 & NLD & $1979 q 1$ & -5.6 \\
\hline EST & $2008 q 1$ & -4.4 & ISL & $2014 q 4$ & -4.0 & NLD & $1980 q 2$ & -2.5 \\
\hline EST & $2008 q^{3}$ & -2.1 & ISR & $2001 q 2$ & -2.4 & NLD & $1982 q 2$ & -3.1 \\
\hline EST & $2008 q 4$ & -11.2 & ISR & $2001 q^{3}$ & -2.5 & NLD & $1982 q 4$ & -2.8 \\
\hline EST & $2009 q 1$ & -4.8 & ISR & $2006 q 3$ & -2.0 & NLD & $2009 q 1$ & -4.0 \\
\hline EST & $2009 q 2$ & -3.9 & ITA & $1974 q 4$ & -2.7 & NOR & $1984 q 2$ & -2.1 \\
\hline EST & $2009 q 3$ & -3.3 & ITA & $1975 q 1$ & -2.3 & NOR & $1987 q^{3}$ & -2.5 \\
\hline FIN & $1971 q 1$ & -5.9 & ITA & $2008 q 4$ & -3.0 & NOR & $2008 q 4$ & -3.0 \\
\hline FIN & $1973 q 2$ & -3.1 & ITA & $2009 q 1$ & -3.5 & NZL & $1989 q 3$ & -4.9 \\
\hline FIN & $1980 \mathrm{q} 4$ & -3.4 & JPN & $1974 q 1$ & -4.4 & NZL & $1991 q 1$ & -3.9 \\
\hline FIN & $1986 q 4$ & -2.6 & JPN & $1989 q 2$ & -2.2 & NZL & 1992q3 & -2.6 \\
\hline FIN & 1990q3 & -2.3 & JPN & $1994 q 2$ & -2.0 & NZL & $1997 q 4$ & -2.4 \\
\hline FIN & 1991q1 & -2.7 & JPN & $1994 q 4$ & -2.0 & NZL & $2008 q 2$ & -2.3 \\
\hline FIN & 1991q2 & -2.3 & JPN & $1998 q 1$ & -2.8 & NZL & $2010 q 3$ & -2.3 \\
\hline FIN & $1991 q 4$ & -2.4 & JPN & $2001 q^{3}$ & -2.1 & POL & $1996 q 4$ & -4.0 \\
\hline FIN & $2008 q 4$ & -3.1 & JPN & $2008 q 2$ & -2.1 & POL & $1998 q 4$ & -2.5 \\
\hline FIN & $2009 q 1$ & -7.6 & JPN & $2008 q^{3}$ & -2.0 & PRT & $2008 q 4$ & -2.1 \\
\hline FIN & $2012 q 2$ & -2.3 & JPN & $2008 q 4$ & -4.3 & PRT & $2009 q 1$ & -3.1 \\
\hline FRA & $1974 q 4$ & -2.4 & JPN & $2009 q 1$ & -5.0 & PRT & $2011 q 4$ & -2.4 \\
\hline FRA & $2008 q 4$ & -2.3 & JPN & $2011 q 1$ & -2.9 & PRT & $2012 q 2$ & -2.2 \\
\hline FRA & $2009 q 1$ & -2.3 & JPN & $2014 q 2$ & -2.9 & PRT & $2012 q 4$ & -2.4 \\
\hline GBR & $1979 q 3$ & -2.7 & KOR & $1997 q 4$ & -2.3 & SVK & $1999 q 1$ & -4.3 \\
\hline GBR & $1980 q 2$ & -2.5 & KOR & $1998 q 1$ & -8.8 & SVK & $1999 q 2$ & -2.8 \\
\hline GBR & $2008 q^{3}$ & -2.3 & KOR & $1998 q 2$ & -2.4 & SVK & $2008 q 1$ & -3.6 \\
\hline GBR & $2008 q 4$ & -2.8 & KOR & $2000 q 4$ & -2.5 & SVK & $2009 q 1$ & -10.1 \\
\hline GBR & $2009 q 1$ & -2.2 & KOR & $2003 q 1$ & -2.4 & SVN & $2008 q 4$ & -4.2 \\
\hline GRC & $2009 q^{1}$ & -5.4 & KOR & $2008 q 4$ & -5.1 & SVN & $2009 q 1$ & -5.0 \\
\hline GRC & $2010 q 1$ & -2.4 & LTU & $2008 q^{3}$ & -2.4 & SWE & $1993 q 1$ & -2.7 \\
\hline GRC & $2010 q 2$ & -3.5 & LTU & $2008 q 4$ & -2.2 & SWE & $2008 q 4$ & -4.5 \\
\hline GRC & $2010 q 3$ & -4.1 & LTU & $2009 q 1$ & -13.6 & SWE & $2009 q 1$ & -2.7 \\
\hline GRC & $2010 q 4$ & -2.2 & LTU & $2009 q 2$ & -2.4 & SWE & $2011 q 4$ & -2.4 \\
\hline GRC & $2011 q 1$ & -3.5 & LTU & $2009 q 4$ & -2.6 & USA & $1980 \mathrm{q} 2$ & -2.8 \\
\hline GRC & $2011 q 2$ & -2.3 & & & & USA & $1982 q 1$ & -2.4 \\
\hline GRC & $2011 q 3$ & -2.9 & & & & USA & $2008 q 4$ & -2.9 \\
\hline GRC & $2011 q 4$ & -3.8 & & & & USA & $2009 q 1$ & -2.1 \\
\hline GRC & $2012 q 2$ & -2.5 & & & & & & \\
\hline GRC & $2013 q 1$ & -2.5 & & & & & & \\
\hline HUN & $2008 q 4$ & -3.9 & & & & & & \\
\hline HUN & $2009 q 1$ & -4.4 & & & & & & \\
\hline HUN & $2012 q 1$ & -2.7 & & & & & & \\
\hline
\end{tabular}

Note: All growth rates are demeaned, i.e. country specific growth averages are subtracted from the observed growth rate. 